\title{
Selling Hope, Selling Risk: Some Lessons for Law from Behavioral Economics About Stockbrokers and Sophisticated Customers
}

\author{
Donald C. Langevoort $†$
}

When risky investments go wrong, brokers and customers may blame each other for the misfortune. Courts and others resolving these disputes must then decide whether the broker withheld information about the risk, or whether the customer knew about the risk and simply made a bad decision. This Article argues that the choice of explanations is not nearly so stark as it may appear. Drawing on research in behavioral economics, the Article develops an account of why brokers are tempted to mischaracterize an investment's level of risk, and why sophisticated investors may make excessively risky investment choices. The centerpiece of this account is trust: brokers are highly motivated to cultivate their customers' trust, and customers have powerful incentives to respond. This trust creates a sustainable opportunity for both conscious and unconscious exploitation by the broker. The Article then explores the legal and regulatory implications of this trust-based account, arguing for meaningful risk disclosure requirements even when the investor is sophisticated.

\section{INTRODUCTION}

"[T] Cards] have done some pretty wild stuff. And you know, they probably do not understand it quite as well as they should. I think that they have a pretty good understanding of it, but not perfect. And that's like perfect for us."

Copyright $\odot 1996$ California Law Review, Inc.

$\dagger$ Lee S. \& Charles A. Speir Professor of Law, Vanderbilt University. Thanks are due to Elliott Weiss and Tamar Frankel for their helpful cormments.

1. In the Matter of BT Securities Corp., Exchange Act Release No. 35,136, [1994-95 Transfer Binder] Fed. Sec. L. Rep. (CCH) I 85,477, at 86114 (Dec. 22, 1994). The Bankers Trust-Gibson matter and a similar set of allegations involving the purchase of derivatives by Procter \& Gamble are detailed in Carol J. Loomis, Untangling the Derivatives Mess. ForTune, Mar. 20, 1995, at 50. 
-Tape recording of a Managing Director at Bankers Trust, discussing the sale of derivatives to Gibson in a series of transactions that ultimately resulted in a $\$ 20$ million loss.

The mutual finger-pointing that often occurs in disputes between stockbrokers and their customers is a predictable drama in the field of investments. After suffering large losses, some customers will blame their brokers for giving bad advice or failing to make candid disclosure of the risks involved. The customer's complaint almost always tells the story of a greedy broker abusing the customer's trust in pursuit of commission income. The broker's response typically describes a customer choosing to take risks to satisfy a lust for wealth and who now cannot accept responsibility for the random misfortune that investment risk taking sometimes brings. This characterization fits disputes ranging from the high-visibility battle between the Orange County Treasurer's Office and Merrill Lynch over multi-billion dollar losses from trading in derivatives, ${ }^{2}$ to the far more mundane suitability and churning claims that make up a large part of the hundreds of customer-broker disputes settled, arbitrated, or litigated each year in the United States.

When the investor is palpably unsophisticated-some modern variant of the proverbial "widow and orphan" scenario-both securities regulation and common law tend to be quite solicitous. But most people with sizable amounts of money to invest, the brokerage industry's prized prospects, have at least basic educational and occupational competence. Many have had successful business or professional careers and have been investing for some time. In cases such as Gibson Greeting Cards or Orange County, the buyers were professional investment managers acting on behalf of wealthy clients, corporations or financial institutions. In these situations, the buyer's apparent naivveté is harder to explain. Thus, we tend to be skeptical of claims of broker overreaching; we suspect such investors probably should have known better than to trust the seller, and perhaps did know better but simply succumbed to hubris or greed. ${ }^{3}$

This Article is an effort to understand why otherwise sophisticated investors seem with disturbing frequency to buy investments they later claim not to have fully understood, thereby adding unanticipated risk to

2. E.g., Marc Levinson, Read It and Weep, NewsweEK, Dec. 19, 1994, at 46; see also Jeanette Redmond, Note, State and Local Government Entities: In Search Of... Statutory Authority to Enter Into Interest Rate Swap Agreements, 63 Ford. L. REv. 2177, 2211-17 (1995). The most thoughtful recent discussion of the derivatives problem that has enveloped Orange County and many financial institutions is Henry T.C. Hu, Hedging Expectations: "Derivative Reality" and the Law and Finance of the Corporate Objective, 73 TEX. L. REv. 985 (1995).

3. The issue of investor sophistication in securitics regulation generally is explored in C. Edward Fletcher, III, Sophisticated Investors Under the Federal Securities Laws, 1988 DUKE LJ. 1081. 
their portfolios. ${ }^{4}$ This question poses interesting practical and conceptual considerations. Whoever must assign responsibility or blame in these sophisticated investor disputes will find that the task is vexing. Most investment sales interactions are oral, occurring either over the telephone or in face-to-face meetings. Following the sale, broker and customer rarely agree as to what was said and understood about the investments. The parties' reconstructed accounts sound sanitized and self-serving; it is doubtful that they recall events accurately or completely anyway. When written risk disclosure documentation is available, there is often an argument about whether or when it was given to the customer, not to mention its candor and completeness.

Because accounts conflict in these ways, the decision maker will tend to focus on the classic elements of a circumstantial case: motive and opportunity. As noted, the customer's case emphasizes the broker's motive in gaining commission or mark-up profits by misstating or concealing risk, or promising inflated returns. The plaintiff usually portrays opportunity as the abuse of the trust and reputation that brokers are trained to cultivate so carefully. The broker's lawyer will likely respond with a powerful list of behavioral assertions predictable to those versed in law and economics:

(1) A broker's dominating interest is in developing long-term customer relationships in order to generate repeat business in a highly competitive market;

(2) For this reason, neither individual brokers nor their firms systematically cheat their customers, because the threat of loss of business that would follow from customer dissatisfaction would deprive them of far more future income than the single cheating opportunity would offer;

(3) It is irrational even to try to misrepresent or conceal risks from a sophisticated customer. Since these customers are generally familiar with investment risk-return relationships, they can readily detect such cheating and terminate the relationship;

(4) Therefore, the broker's story of sufficient candor is the more credible one: the customer understood the gamble but opted for the

4. The question of what constitutes an appropriate level of risk is, of course, a subjective one. For our purposes, excessive portfolio risk is risk disproportionate to the needs and objectives of the investor (however defined by the investor), or risk inadequately compensated for in price. To be sure, it is problematic to view risk in hindsight; there is no reason to assume that because an investor lost money, the investment was imprudent. We must be careful not to commit the basic cognitive error inherent in the so-called hindsight bias: the natural tendency to overweight the probability that an event would come to pass after one is told that later it did come to pass. See Baruch Fischhoff, For Those Condemned to Study the Past: Heuristics and Biases in Hindsight, in JUdGMENT UNDER UnCERTAINTY: HeURISTICS AND BIASES 335 (Daniel Kahneman et al. eds., 1982); Kim A. Kamin \& Jeffrey J. Rachlinski, Ex Post Does Not Equal Ex Ante: Determining Liability in Hindsight, 19 LAw \& Hum. Behav. 89 (1995). 
high-risk/high-return strategy, and now struggles to shift responsibility for the losses to the seller. Any overly optimistic broker statements were nothing more than habitual sales talk, readily discounted by any reasonable customer. In those cases that involve purchases by financial institutions, an additional claim will be that the institution's own system of internal controls insufficiently checked the foolishness, ego, or greed of its employees.

The customer's lawyer will counter with a simple question: If all this is so, why are there so many notorious examples of broker cheating $?^{5}$ The broker will retort that those are highly aberrant, unrepresentative acts of a handful of foolish "rogue brokers" who either repent or are expelled from the industry. ${ }^{6}$ The customer will respond in turn with cynical disbelief.

In the end, dispute resolvers faced with this sort of conflict will probably employ some rough heuristics to decide the merits of each case. They will invoke social constructs drawn from their own experience and imagination about the ways in which brokers normally deal with their customers, and how customers normally choose investments. If these mental images reflect a world full of Machiavellian brokers and stressed customers overloaded by investment data, necessarily dependent on expert sources, even the sophisticated customer stands a good chance of succeeding. If investors are instead construed as naturally suspicious of securities salespeople, and generally able to fend for themselves, the decision will probably come down against the customer whose diligence falls short of the imagined norm.

This Article proceeds from the premise that these stereotyped images are incomplete and misleading. A less polarized perspective is needed to assess the plausibility of the claims likely to arise in disputes involving the sale of securities by professional salespeople in a broad

5. There are numerous books and magazine articles detailing the greed of the brokerage industry, which naturally must be viewed with some suspicion that the accounts are sharpened to make them more interesting. Still, they offer intriguing anecdotal insights. See C. DAvID CHASE, Mugged on Wall STREet: AN INSIDER Shows You How to Protect Yourself aNd Your Money from the Financial Pros (1987); Thomas D. Saler, Lies Your Broker Tells You: What to Watch for and Still Achieve Financial Security (1989); see also Ruth Simon, Which Brokerage Firms Treat You Right, Which Don't, and What You Can Do About It Today, MONEY, Apr. 1995, at 92 (surveying brokerage firms' practices and suggesting the presence of widespread opportunism).

6. The image of the aberrant "rogue broker" is commonplace; even the SEC seems willing to accept the rhetoric. See SEC Will Probe Smaller Sized Firms, Levitt Tells House Rogue Broker Hearing, 26 SEc. ReG. \& L. REP. (BNA) 1231 (Scpt. 16. 1994). At the same time the SEC has become increasingly aggressive in policing the industry as a whole. See McLucas Favors Incarceration in "Clear Cut" Sales Practice Cases, 27 SEC. REG. \& L. REP. (BNA) 396 (Mar. 10, 1995). There is no doubt that the securities industry has a strong economic incentive to promote the impression that manipulative sales practices are limited to a small subset of brokers, for their entire business is built on customer trust. 
range of institutional and retail settings. ${ }^{7}$ In turn, a more nuanced view will generate better strategies for regulating the brokerage industry ex ante. In my analysis, the issue of trust emerges as the pivotal consideration. ${ }^{8}$ The central claim is that once a broker successfully cultivates trust, willing reliance by the sophisticated investor-imprudent though it may seem in hindsight-is quite likely and, for that reason alone, worthy of some protection. It challenges the view that broad-based trust characterizes only the unsophisticated investor, or that sophistication implies either little need to rely on the advice of brokers and others who profess investment expertise or a ready ability to spot and respond to their opportunistic behavior.

Part I of this Article seeks to develop an explanation for brokercustomer sales interactions, a way of thinking about the behavior of the parties that leads to a more honest understanding of why bad things happen in investment sales. Although bad decisions by sophisticated buyers and instances of seller cheating (i.e., any abuse of trust to sell an investment that is inconsistent with the buyer's best interests) are surely the exception rather than the rule, this Part shows why they should not be trivialized as "random noise" in the study of investing. Part II explores how this understanding affects our evaluation of the basic legal questions arising in this area of securities law. Here I try to clarify and inform the confused state of the law on issues such as the fiduciary character of broker-customer relationships, the customer's duty to read, and the nature and source of a risk disclosure obligation. The goal is a moderate expansion of the protection afforded sophisticated investors

7. This range is sufficiently broad, running from middle-income investors with basic educational and business experience all the way to professional investment managers, that it is dangerous to generalize about the behavioral tendencies of investors within it. Nonetheless, I believe that the commonalities outweigh the differences, and so I have chosen a wide angle lens for observation and analysis. However, I do acknowledge that some of the particular behavioral traits described in this Article will apply far more strongly to some segments of the sophisticated investor population than others. No doubt an Article focusing simply on one segment (e.g., institutional investment agents) would present the behavioral influences with different emphasis.

Some clariflcation of terminology may also be appropriate here. Although this Article frequently uses the term "security," the reference is non-technical. Many forms of investment-some derivatives, most commodities, etc.-are not securities within the meaning of the federal securities laws. The descriptive analysis that follows, however, applies regardless of the overarching legal structure, as does much of the normative discussion. Similarly, this Atticle will use the term "broker" to refer generally to people whose job it is to sell investments, not just "securities." This includes the retail registered representative as well as the institutional salesperson.

8. This Article thus seeks to contribute to the body of literature on trust relationships in economic exchange settings. See generally TRUST: MaKING AND Breaking CoOperative Relationships (Diego Gambetta ed., 1988); Niklas Luhmann, Trust aNd Power (1979); David F. Haas \& Forrest A. Deseran, Trust and Symbolic Exchange, 44 Soc. Psychol. Q. 3 (1981); Carol M. Rose, Trust in the Mirror of Betrayal, 75 B.U. L. REv. 531 (1995); G. Richard Shell, Opportunism and Trust in the Negotiation of Commercial Contracts: Toward a New Cause of Action, 44 VAND. L. REV. 221 (1991). 
based upon an analysis of the trust and reliance generated in the brokercustomer relationship. Without suggesting that the sophistication of a particular retail or institutional customer is irrelevant to determining how the broker should behave in a particular setting, simply labeling an investor "sophisticated" should mean nothing in terms of the broker's basic legal obligations of honesty and candor. At the same time, this Part cautions against the overbroad protectionism that follows when broker-customer relationships are broadly fiduciarized.

The methodology is largely theoretical, drawing from the social science literature on risk taking and cognition. This work is produced by economists and psychologists and is sometimes referred to as behavioral economics. ${ }^{9}$ Relying in part on the conventional cognitive materials that dominate the literature, I also pay special attention to research in motivated reasoning, exploring the reasons why people persistently act inconsistently with the image of the Bayesian fact-finder. ${ }^{10}$

Because I rely so heavily on a controversial body of research that is often tentative and sometimes subject to conflicting interpretations, " all

9. Or behavioral decision theory. For useful overviews, see generally RoBYN M. DAWEs, Rational Choice in an Uncertain World (1988); Robin M. Hogarth, Judgement and CHolce (2d ed. 1987); John W. Payne et al., Behavioral Decision Research: A Constructive Processing Perspective, 43 ANN. Rev. Psychol. 87 (1992); Paul Slovic et al., Decision Making, in 2 Stevens' HANDBooK of Experimental Psychology 673 (Richard C. Atkinson et al. eds., 1988). Even Newsweek magazine has recently commented on the growing influence of this body of work. See Marc Levinson, Dismal Science Grabs a Couch, Newsweek, Apr. 10, 1995, at 41. Research in this area has come to have a significant impact on legal scholarship in a variety of fields. See, e.g., Ward Edwards \& Detlof von Winterfeldt, Cognitive Illusions and Their Implications for the Law, 59 S. CAL. L. REv. 225 (1986) (areas of case confusion, discrediting expert witnesses, and causing decisionmakers to reach erroneous decisions); Melvin A. Eisenberg, The Limits of Cognition and the Limits of Contract, 47 STAN. L. REv. 211 (1995) (contract law); Russell Karobkin \& Chris Guthrie, Psychological Barriers to Litigation Settlement: An Experimental Approach, 93 Mrch. L. REv. 107 (1994) (litigation settlements); Thomas Ulen, Cognitive Imperfections and the Economic Analysis of Law, 12 HaMLine L. Rev. 385 (1989).

10. Purely cognitive research looks largely at the problem of bounded rationality, and considers the mental strategies people use to manage the processing of large amounts of information, especially under conditions of ambiguity and uncertainty. See, e.g., Richard Nisbett \& LeE Ross, Human lNFERENCE: STRATEgies AND SHORTCOMINGS OF SOCiAL JUDGMENT (1980). Motivational cognitions deal with explanations such as the enhancement of self-esteem or the desire for fairness in cognitive processes. See, e.g., Susan T. Fiske \& Shelley E TAylor, Social Cognition 13 (2d ed. 1991); Zivi Kunda, The Case for Motivated Reasoning, 108 PsYCHOL. BULL. 480 (1990).

11. The controversy is discussed extensively in the literature. See, e.g., Lola L. Lopes, Psychology and Economics: Perspectives on Risk, Cooperation and The Marketplace, 1994 ANN. Rev. Psychol. 197 (Lyman W. Porter \& Mark R. Rosenzweig eds., 1994) (discussing how the disciplinary perspectives of psychology and economics address decision making under risk); Robin M. Hogarth \& Melvin W. Reder, Prefatory Note: The Behavioral Foundations of Economic Theory, $59 \mathrm{~J}$. Bus. S181, S181 (1986) (introducing symposium whose objective is to bring together economists and psychologists in a discussion of "systematic departures from the dictates of rational economic behavior"). For criticisms from legal academics of the use of these materials, see, e.g., Alan Schwartz, Proposals for Product Liability Reform: A Theoretical Synthesis, 97 YALE LJ. 353, 380-82 (1988); Robert E. Scott, Error and Rationality in Individual Decision-Making, 59 S. CAL. L. REv. 329 (1986). Although behavioral economies takes direct issue with the assumptions of conventional 
the hypotheses made here are preliminary ones, deserving more formal elaboration and empirical testing. I make no attempt to predict how often investors assume excessive risk, or how often brokers overreach-I only suggest that both motivation and opportunity exist for such behavior to occur and to persist. That I must rely so much on theoretical research is unfortunate. Sadly, however, there is a dearth of publicly available studies of broker-customer interactions. ${ }^{12}$ Hard data is lacking that attempts to measure the extent of reliance on broker representations among investor classes, the frequency and intensity of the interactions, the strategies employed by brokers to make sales, the role of written disclosure materials in these interactions, and other relevant factors. Until this kind of empirical work is done, theory is the best base from which to build.

In exploring this subject, I grapple with one of the more puzzling phenomena in economics, finance, and securities regulation: Why do investors so readily pay for and accept so much investment advice, especially from sources subject to palpable conflicts of interest? ${ }^{13}$ Indeed, there is little affirmative evidence that systematically "market-beating" advice is im fact distributed, except perhaps to a small number of valued, high-paying advisory clients. Rational investors with no special proprietary information or expertise to exploit can pursue normal returns at little cost. $^{14}$ Yet the securities brokerage industry remains a healthy,

economics, it has yet to develop an elegant theory to supplant the rational actor paradigm. Its findings are usually generated by laboratory experimentation (often with college-age subjects), which lacks the richness and repetition of real life. Nonetheless, the rapidly growing use of behavioral economics in the top-tier legal, economic, and finance literature indicates its immense appeal as an effort toward explaining the ample evidence of suboptimal behavior readily observable in everyday life. The normative conclusions I draw in this Article are offered notwithstanding my recognition of the limits of this body of research. I sense that a theoretical construct built upon a basis of significant scientific support and corresponding to a fair amount of common intuition and experience should be well received by academics, lawyers, and policymakers.

12. For examples of some empirical work, see Paul B. Andreassen, On the Social Psychology of the Stock Market: Aggregate Attributional Effects and the Regressiveness of Prediction, $53 \mathrm{~J}$. Personality \& Soc. Psychol. 490 (1987); Paul Slovic et al., Analyzing the Use of Information in Investment Decision Making: A Methodological Proposal, 45 J. Bus. 283 (1972). Proprietary data exists in abundance, no doubt, since brokerage firms do heavy amounts of market research. But little of it becomes public. Most unfortunate has been the failure of the SEC to endeavor to develop a useful body of empirical information regarding broker-customer interactions. See Donald C. Langevoort, Theories, Assumptions, and Securities Regulation: Market Efficiency Revisited, $140 \mathrm{U}$. PA. L. REV. 85I, 920 (1992).

13. For the most recent scholarly effort to address this question, see Lynn A. Stout, Are Stock Markets Costly Casinos? Disagreement, Market Failure and Securities Regulation, 81 VA. L. REv. 61I, 641-42 (1995) (arguing that rational investors form "heterogenous expectations" regarding stock performance to which brokers contribute by providing only part of available stock-valuation information). But see Paul G. Mahoney, Is There a Cure for "Excessive" Trading, 81 VA. L. REv. 7I3 (I995) (rejecting Stout's rational investor model and raising an agency-based rationale for irrational investment decisions).

14. See, e.g., Burton G. Malkiel, A Random Walk Down Wall Street $422-32$ (6th ed. 1996). The classic suggestion that it is imprudent for an investor to rely solely on stock research is 
growing, profitable one-in significant part through the advice given by or through a highly compensated group of professional salespeople. Any understanding of customer-broker disputes must ultimately come to grips with this paradox.

And there is more to the paradox than simply an insight about investor protection. The internal workings of our economic system are greased by countless forms of sales interactions. If a large percentage of purchases made in both retail and institutional settings were simply transactions between rational buyers and sellers-with salespeople playing no role other than providing product information tailored to the customer's specific needs-it is hard to believe that so many resources would be devoted to recruiting, training, motivating, and compensating salespeople. ${ }^{15}$ It should be recognized that intuitively, the role of the salesperson is to shape demand, and, whether or not we like to admit it, such a role extends to interactions with sophisticated customers. Understanding the cognitive and motivational mechanics of broker-customer sales interactions may offer a glimpse of a phenomenon that is pervasive in America's commercial culture but dimly understood as a legal subject. ${ }^{16}$

INVESTORS, BROKERS AND RISK

\section{A. Investors and Risk}

Our inquiry begins with the question of why investors take risks, and what behavioral factors influence the level of risk they assume in

John H. Langbein \& Richard A. Posner, Market Funds and Trust Investment Law, 1976 AM. B. FOUND. RES. J. 1. There will be many cases where a well-organized market's efficiency producing properties will assure that prices are in some sense "fair" or otherwise limit seller opportunism. See, e.g., Ronald Gilson \& Reinier H. Kraakman, The Mechanisms of Market Efficiency, 70 VA. L. REv. 549 (1984). My interest in this Article is not in market efficiency. But investor abuse can occur even if the stock prices at which they trade are fair (through problems like chuming, unsuitability, etc.). Furthermore, many investment products are sold in markets with limited efficiency characteristics. And there is much debate today about the validity of the efficient market hypothesis. See, e.g., Jeffrey N. Gordon \& Lewis A. Kornhauser, Efficient Markets, Costly Information, and Securities Research, 60 N.Y.U. L. REv. 761 (1985); Langevoort, supra note 12; Louis Lowenstein, Efficient Market Theory: Let the Punishment Fit the Crime, 51 WASH. \& LEE L. REv. 925 (1994); Stout, supra note 13. There are commonplace anecdotal reports of investment professionals regularly beating random stock selections. E.g., John R. Dorfman, Pros Thoroughly Trounce Dart Throwers, WaLL ST. J., Aug. 17, 1993, at C1. One must wonder, however, whether some of the price rise following such wetl-publicized recommendations might not be something of a self-fulfilling prophecy. For purposes of this Article, we will assume that market efficiency is significant but incomplete, so that interesting issues of investor protection remain in some settings.

15. See Donald McCloskey \& Arjo Klamer, One Quarter of GDP is Persuasion, 85 AM. EcoN. Rev. (PAPERS \& Proc.) 191 (1995) (emphasizing the underappreciated role of persuasion in economic activity).

16. For an insightful exploration of the fine line between salesmanship and fraud, see ARTHUR A. LefF, Swindling ANd SElLiNg (1976). 
structuring their portfolios. Because of differing motivational and incentive structures, the analysis will be separate for investors purchasing for their own account and investment managers acting as agents for others.

At the outset, it is important to emphasize the uncertainty that people face when investing. A security is an intangible, a bundle of financial expectations buttressed with varying legal rights. An investor seeking above-normal return has to try to predict the future, in terms of either the fundamental value of the security (expected stream of earnings, adjusted for risk and discounted to present value) or the anticipated reaction of other investors to information about the security. ${ }^{17}$ Even for professional analysts, this effort is at best fraught with ambiguity; for average investors, trying to outperform the market is little more than a form of gambling. Relative investment value is a social construct, not subject to valuation rules that meet standards of scientific precision.

\section{Individual Investors}

Behavioral decision theorists have generated a number of insights relating to decision making that might apply to investment behavior. ${ }^{18}$ For instance, people have a documented tendency to find illusory correlations-to assign cause and effect relationships to wholly independent events. ${ }^{19}$ They also believe that unusual trends have a greater than actual natural life span, rather than recognizing the more predictable reversion to mean. ${ }^{20}$ People place too much weight on recent or highly salient data at the expense of information less readily subject to recall. Yet predicting that these and other common "cognitive illusions" will systematically affect investor behavior is problematic. Psychologists involved in decision theory often point out that these mental shortcuts are ways of simplifying the decision-making process in everyday tasks when there is insufficient time or reason to give more careful attention to the cognitive task at hand. ${ }^{21}$ Even for sophisticated investors, putting

17. The sense that investors try to outguess each other by trying to predict others' reactions to information goes back at least to Keynes. For modern restatements of the Keynesian perspective, see generally David Dreman, The New Contrarian Investment Strategy (1982); Robert J. ShILlER, MARKET Volatility (1989). However, even in an efficient market, optimal prices are often wrong as predictions of the future. J.G. Cragg \& Burton G. Malkiel, The Consensus and Accuracy of Some Predictions of the Growth of Corporate Earnings, 23 J. Fin. 67, 82-83 (1968).

18. See supra note 10 and accompanying text; see also DREMAN, supra note 17, and Langevoort, supra note 12 , at $858-65$ (using these insights to understand investor decision making). Much of the "noise trader" literature uses economic psychology to explain the suboptimal behavior of organized financial markets. E.g., Langevoort, supra note 12 , at 866-75.

19. E.g., DAwEs, supra note 9, at 112-19.

20. Id. at $81-87$.

21. See Arie W. Kruglanski, The Psychology of Being Right: The Problem of Accuracy in Social Perception and Cognition, 106 PsychoL. BuLL. 395, 402-07 (1989). In their study of decision making, Janis and Mann note how situational variables can move judgment either in the direction of 
money at risk is a siguificant, if not unusual, step. Arguably, at least, they are motivated to act fairly diligently. Our inquiry, therefore, is directed first and foremost at the motivations that people bring to investment decision making. What drives individual investor choices that might affect their exercise of diligence?

One of the central tenets of conventional economics is risk aversion; most people are naturally wary of putting their hard-earned capital in the hands of others in the pursuit of uncertain investment gains. Behavioral decision theory partially confirms this principle, recognizing a status quo bias in risk taking. ${ }^{22}$ This suggests that knowingly investing in high-risk settings is somewhat aberrant, and requires the intervention of a fairly strong offsetting motivational influence. Moreover, there is little doubt that the act of investing is anxiety-producing, given the high degree of informational ambiguity and the potential risk of loss. People generally have to be prodded to take such a step, and their decisions are thus likely to be quite deliberate.

To be sure, some risky investments can occur without the investor appreciating the level of risk that is added to the overall portfolio. This often is the issue in customer-broker disputes, and I shall say much more about it later on. For now, let us accept arguendo the standard retort that sophisticated investors at least understand that risk and return operate in tandem: the possibility of above-average return inevitably carries with it above-average risk. The question, therefore, is what motivations are likely to overcome risk-aversion and prompt greater risk taking?

The first is the obvious: a desire to make money. In our society the pursuit of wealth is pervasive. Simply labeling this as greed is misleading. Significant additions to personal wealth not only permit the acquisition of more material possessions, but are key to a range of culturally conditioned human needs. ${ }^{23}$ Wealth provides security and autonomy, reducing the anxiety of uncertain futures and the need to be servile to the whims of others. More generally, wealth is a primary measure of relative status in society, and there is evidence that much of our behavior and cognition is devoted to the search for a comparatively

defensive bolstering or hyper-vigilance, with the nature of the induced stress being a dominating influence. See Irving L Janis \& Leon ManN, Decision Making: a Psychological analysis of Conflict, Choice, ANd CoMmitment 52-64 (1977).

22. E.g., Daniel Kahneman et al., Anomalies: The Endowment Effect, Loss Aversion, and Status Quo Bias, J. ECON. PERSP., Winter 1991, at 193; see also Raymond S. Hartman et al., Consumer Rationality and the Status Quo, 106 Q.J. EcoN. 141 (1991).

23. Salespeople are frequently taught to understand the "hierarchy of needs" first developed by psychologist Abraham Maslow, in which the "need" for wealth ranks highest. See, e.g., B. ROBERT Anderson, Professional Selling 37-38 (3d ed. 1987). For an unusually sophisticated practitioner's view of investment purchase decisions, see STEven R. Drozdeck \& KARL F. GrETz, The Broker's Edge: How to Sell Securities in ANY Market, 162-82 (1995). 
superior niche in life. ${ }^{24}$ These needs provide ample motivation for many people to seek and accept significant investment risk, for significant gambles may be required to change ineaningfully one's standard of living. ${ }^{25}$

A second motivation is the play value of gambling. There is a visceral thrill to placing a high payoff bet, a thrill that resonates in lives otherwise often characterized by high degrees of routine and boredom. The success of lotteries, publishers' contests, and both the legal and illegal gambling industries is ample testimony to the power of this motivation. ${ }^{26}$

A further motivation, loss aversion, is central to much of the following discussion. Although behavioral decision theory accepts riskaversion as a characteristic in the pursuit of gains, ${ }^{27}$ it also argues that risk-seeking behavior is more commonplace when a person perceives the possibility of loss. ${ }^{28}$ People place greater weight on the possibility of losing what they already "have" than on gaining what they don't. But their view of what they have is not so much an accounting of material or emotional possessions as it is a set of expectations. In this sense, people establish target expectation levels-"mental accounts"29-in terms of both absolute performance and relative position vis-à-vis significant others. Risk aversion characterizes choices viewed in terms of the possibility of exceeding the target, while the possibility of falling short of the target represents a potential loss that triggers a greater preference for

24. See Robert H. Frank, Choosing the Right Pond: Human Behavior and the Quest For STatus (1985); William M. Klein \& Zivi Kunda, Maintaining Self-Serving Social Comparisons: Biased Reconstruction of One's Past Behaviors, 19 Personality \& Soc. Psychol. Bull. 732, 734 (1993) (arguing that people's beliefs about themselves are often biased to maintain a belief of superiority over others); Vai-Lam Mui, The Economics of Envy, 26 J. ECON. BeHAv. \& ORG. 311, 312 (1995) (exploring "the role of envy in provoking sabotage or retaliation against others using the economists' traditional rational choice framework").

25. This motivation is emphasized in the literature on gambling, and has recently been stressed as a "rational" explanation for gambling behavior. See Edward J. McCaffery, Why People Play Lotteries and Why It Matters, 1994 WIS. L. REV. 71.

26. On the appeal of lotteries to different types of people, see Charles T. Clotfel rer \& Philip J. CoOK, Selling Hope: State LotTerJes in AMERICA 72-81 (1989). Robert Shiller has emphasized the play value of gambling as an explanation for investor behavior. See SHILLER, supra note 17 , at $58-60$.

27. See supra note 22 and accompanying text.

28. This is part of the status quo bias, which is generalized in what is sometimes called "prospect theory." See Amos Tversky \& Daniel Kahneman, Advances in Prospect Theory: Cumulative Representation of Uncertainty, 5 J. RISK \& UNCERTAINTY 297 (1992); Amos Tversky \& Daniel Kahneman, Rational Choice and the Framing of Decisions, 59 J. Bus. S251 (1986). For a good illustration of the use of prospect theory in finance, see Shlomo Benartzi \& Richard $H$. Thaler, Myopic Loss Aversion and the Equity Premium Puzzle, 110 QJ. EcoN. 73 (1995); in law, see Roger G. Noll \& James E. Krier, Some Implications of Cognitive Psychology for Risk Regulation, 19 J. LEG. STUd. 747 (1990).

29. For a discussion of mental accounts generally, see Richard H. Thaler, Toward a Positive Theory of Consumer Choice, in Quasi-Rational Economics 3 (1991). 
risk. $^{30}$ The precise reasons for this phenomenon are not entirely clear; however, a correlation between the desire to achieve a target level and the desire to preserve or enhance status or self-esteem, one of the most powerful motivations in social cognition, would not be surprising. ${ }^{31}$

Under this formulation, we can derive additional explanations for investor risk-taking behavior. To the extent that an investor senses the serious possibility of relative loss, there will be an increased willingness to accept risk. One can readily imagine situations when assessing a situation from the perspective of potential loss-the phenomenon of "loss framing"-will occur. An investor on a losing streak, for instance, may well decide that greater risk is necessary to achieve the target. ${ }^{32}$ Similarly, an investor with a long-term goal of even moderate financial security might view current investment choices in terms of a need not to fall short of that expectation-not to lose ground. And an investor fearing the erosive effects of inflation or diminishing returns may see risk taking as necessary to preserve the status quo.

Social comparisons can also generate loss framing. ${ }^{33}$ A perception that significant others have recently generated more wealth in their investments, or are being offered and are likely to seize some tempting opportinity, can readily translate into fear of loss of status. Prospect theory predicts that people take more risk to keep up with others than to move ahead of them. Thus, a person who has foregone investing in the early stages of what turns out to be a bull market for stocks, or who misses a salient run-up in the price of a stock is likely to feel substantial

30. See Lola L. Lopes, Between Hope and Fear: The Psychology of Risk, 20 AdvanczS Experimental Soc. Psychol. 255 (1987); James G. March, Variable Risk Preference and Adaptive Aspirations, 9 J. Econ. Behav. \& ORG. 5 (1988).

31. On the role of self-esteem as a pervasive-and often distorting-influence on cognition, see, e.g., Elliot Aronson, The Social Animal 169-71 (7th ed. 1995); David Dunning et al., $A$ New Look at Motivated Inference: Are Self-Serving Theories of Success a Product of Motivational Forces?, 69 J. Personality \& Soc. Psychol. 58 (1995); Jeff Greenberg et al., Why Do People Need Self-Esteem? Converging Evidence that Self-Esteem Serves an Anxiety-Buffering Function, 63 J. Personality \& Soc. Psychol. 913 (1992); Anthony G. Greenwald, The Totalitarian Ego: Fabrication and Revision of Personal History, 35 AM. PsYCHOL. 603 (1980); Pamela C. Regan et al., Unrealistic Optimism: Self-Enhancement or Person Positivity?, 21 Personality \& Soc. Pyschol. Bull. 1073 (1995). Much of this research derives from the notion of cognitive dissonance: people's way of mediating conflict between attitudes and perception or behavior. For an economic analysis, see George A. Akerlof \& William T. Dickens, The Economic Consequences of Cognitive Dissonance, 72 AM. ECON. REv. 307 (1982). I have relied on this research in motivated reasoning to help explain a variety of legal issues. See Donald C. Langevoort, Ego, Human Behavior and Law, 51 VA. L. REv. 853 (1995).

32. See, e.g., Richard H. Thaler \& Eric J. Johnson, Gambling With the House Money and Trying to Break Even: The Effects of Prior Outcomes on Risky Choice, 36 MGMT. Sct. 643, 656-58 (1990).

33. See Reuven Brenner \& Gabrielle A. Brenner, Gambling and Steculation: A Theory, a History and a Future of Some Human Decisions 21-22 (1990). 
pressure to make up the difference. This may be one explanation (among many) for why investors overreact to both good and bad news. ${ }^{34}$

A separate important motivation relates both to the setting of target expectation levels and to the perception of underlying investment risk. A fair body of research suggests that people (perhaps especially those high in social and economic status) exhibit a predictable overconfidence in their ability to control future events and avoid risks. ${ }^{35}$ Investors probably overrate their stock-picking abilities, ${ }^{36}$ leading to an underestimation of risk.

The natural objection here is that over time investors should learn from their mistakes, acquiring a natural humility. But while this does happen, overconfidence has proven to be a sticky behavioral phenomenon. Again, self-esteem plays a motivating factor. People dwell on successes and attribute them to skill and diligence. Failures are more readily dismissed as the product of chance and other unforeseeable external causes. ${ }^{37}$ Learning is thus difficult with respect to investing. Feedback is neither unambiguous nor immediate. ${ }^{38}$ For any active investor, a number of successes will provide the more heavily weighted source of feedback. Market volatility and the predictable occurrence of bull markets assure that there will be positive feedback to distort. As to losers, most investments continue indefinitely: there is always the hope of reversals of fortune after initial setbacks, and hence no closure. In this sense, a sophisticated investor's optimistic, self-serving schema of

34. See generally Hersh M. Shefrin \& Meir Statman, How Not to Make Money in the Stock Market, Psychol. TODAy, Feb. 1986, at 52 (discussing consumers' tendency to predict future performance of mutual funds based on past results). Overreaction is treated from a finance perspective, with numerous references to the behavioral-based noise trading literature, in Baruch Lev \& Meiring de Villiers, Stock Price Crashes and 10b-5 Damages: A Legal, Economic, and Policy Analysis, 47 StAw. L. REv. 7, 13-22 (1994).

35. E.g., Max H. Bazerman, Judgment in Managerial Decision Making 32-35 (1986); Baruch Fischhoff et al., Knowing With Certainty: The Appropriateness of Extreme Confidence, $3 \mathrm{~J}$. Experimental Psychol.: Hum. Perception \& Performance 552 (1977). Recent research suggests that the illusion of control may be enhanced by the degree of need the subject has for success, raising an apparent link between prospect theory and the illusion of control. Paul M. Biner et al., Need State and the Illusion of Control, 21 Personality \& Soc. Psychol. Bull. 899 (1995).

36. This includes investment experts. See David Hirshleifer et al., Security Analysis and Trading Patterns When Some Investors Receive Information Before Others, 49 J. Fin. 1665, 1686 (1994). The effect of overconfidence and expertise on probability analysis is explored in Chip Heath \& Amos Tversky, Preference and Belief: Ambiguity and Competence in Choice under Uncertainty, 4 J. RISK \& UNCERTAINTY 5 (1991). Besides forming inflated inpressions of themselves, investors are also motivated to convey to others inflated impressions of investment skill.

37. See Thomas Gllovich, Why We Know What Isn't So 75-87 (1991); Martin EP. SELIGMAN, LEARNED OPTIMISM (1991); sources cited supra note 31.

38. Even in the absence of motivation, learning is difficult absent feedback that is prompt and unambiguous. For two good overviews, see Sheryl B. Ball et al., An Evaluation of Learning in the Bilateral Winner's Curse, 48 Organizational Behav. \& Hum. Decision Processes 1, 17-18 (1991); Berndt Brehmer, In One Word: Not From Experience, in JUDGMENT AND DECISIONMaking: An INTERdisciplinary Reader 705 (Hal R. Arkes \& Kenneth R. Hammond eds., 1986). 
competence and expertise can resist downward revision for unusually long periods of time. ${ }^{39}$ Conversely, it will be subject to significant inflation as a result of any hot streak that appears to occur. ${ }^{40}$

Finally, other important attributes of risk assessment in behavioral decision theory bear note. People tend, for example, simply to disregard non-salient low-level probabilities of harm (although they may overreact to low-probability risks made vivid by some recent catastrophe). Life is easier to manage, and far less stressful, if such risks are simply put out of mind. Given the stress otherwise associated with investing, this form of wishful thinking may not be insignificant. ${ }^{41}$ In addition, we should take note of people's tendency to discount risks whose likely occurrence is some time away. ${ }^{42} \mathrm{We}$ all recognize the difficulty of resisting the promise of immediate gratification (whether it be the pleasures of fatty foods or the high yield of a junk bond) when the apparent risks are temporally distant, even if we accept that those risks are significant.

In sum, many motivations are likely to cause even experienced investors to assume significant risk. To some extent, this analysis substantiates the claim that risk taking is the mvestor's own choice, and, hence, responsibility. But recognize two further points. First, many of these motivations will be unconscious, with influences that cannot readily be

39. Related to this is the concept of commitment. Once investors have selected an investment as appropriate, changing direction implies that they have made a mistake. E.g., Hal R. Arkes \& Catherine Blumer, The Psychology of Sunk Cost, 35 Organizational Behav. \& Hum. Decision ProCESSES 124 (1985); Barry M. Staw, The Escalation of Commitment to a Course of Action, 6 ACAD. MGMT. REv. 577 (1981). The concept of commitment is ccntral to much of the work in motivated reasoning, and is the foundation of the notion of cognitive dissonance. In essence, once the commitment is made, facts suggesting that the commitment was an error tend to be filtered out in order to protect the self-concept. This has been noted as a possible explanation for the apparent willingness of some pension funds to keep certain money managers notwithstanding subpar performances. See William M. O'BARR \& John M. Conley, Fortune and Folly: The WEALTH AND POWER OF INSTITUTIONAL INVESTING 91 (1992).

40. For a good application of this phenomenon to managerial behavior, see James G. March \& Zur Shapira, Managerial Perspectives on Risk and Risk Taking, 33 MGMT. SCl. 1404, 1413-14 (1987).

41. See Colin F. Camerer \& Howard Kunreuther, Decision Processes for Low Probability Events: Policy Implications, 8 J. PoL'Y ANAL. \& MGMT. 565 (1989) (discussing phenomenon of ignoring low probability risks in risk analysis); Henry T.C. Hu, Misunderstood Derivatives: The Causes of Informational Failure and the Promise of Regulatory Incrementalism, 102 YALE L.J. 1457, 1488-90 (1993) (discussing "threshold effect" in financial risktaking); Paul Slovic et al., Regulation of Risk: A Psychological Perspective, in Regulatory POLICY and the Social Sciences 241, 260 (Roger G. Noll ed., 1985) (discussing studies indicating "a disinclination to worry about low probability hazards"). For some useful extensions of this propensity to the law of contracts, see Eisenberg, supra note 9, at 223-25; Clayton P. Gillette, Commercial Relationships and the Selection of Default Rules for Remote Risks, 19 J. LEG. STUD. 535 (1990).

42. Cf. George Loewenstein \& Richard H. Thaler, Intertemporal Choice, 3 J. ECON. PERSP., 181, 187 (1989) (discussing tendency to express a smaller discount rate for future losses than for future gains). See also Deborah M. Weiss, Paternalistic Pension Policy: Psychological Evidence and Economic Theory, 58 U. CHI. L. REv. 1275, 1300-06 (1991) (discussing "psychology of impatience and impulsiveness"). 
characterized as deliberate choice. ${ }^{43}$ Motivated reasoning is often formed as self-serving inference and wishful thinking, ${ }^{44}$ in which the underlying desires affect, if not control, decision making. Yet these desires are masked from consciousness by selective perception and rationalization. The investor motivated to take risk is equally motivated to see the investment decision as reasonable and rational. In this sense, risk taking will often take the form of failing to perceive and appreciate risk as opposed to the deliberate assumption of risk. Second, it is precisely these motivations that some brokers will try to manipulate to create customer demand for investment products. Thus, legal responsibility must be assigned in cognizance of the subtle opportunism that tempts brokers. The law may wish to protect unconscious investment motivations from conscious and deliberate manipulation. Before examining the practices of the securities industry, however, I must look at the other important form of sophisticated investor behavior: risk taking by investment agents.

\section{Investors as Agents}

Unlike decisions made by individual investors, investment decisions made by an agent on behalf of one or more owners of the portfolio are the product of a different dynamic. ${ }^{45}$ Risky trading generates gains and losses that do not inure directly to the benefit or disadvantage of the investment manager. By itself, however, this factor must not be overstated, for there is usually a very close correlation between portfolio performance and agent wealth. ${ }^{46}$ Even if pay is not tied directly to

43. See, e.g., Anthony G. Greenwald \& Mahzarin R. Banaji, Implicit Social Cognition: Attitudes, Self-Esteem and Stereotypes, 102 Psychol. Rev. 4 (1995) (discussing "implicit cognition" as opposed to conscious cognitive attitudes).

44. See Robert A. Josephs et al., Protecting the Self from the Negative Consequences of Risky Decisions, 62 J. PersonaltTy \& Soc. PsYchol. 26 (1992). The primary characteristic of motivated reasoning is its bias toward the desired result: the search for information is in terms of discovering a plausible rationale for the result rather than dispassionate evaluation of alternatives. See GrLovich, supra note 37, at 75-87; Peter H. Ditto \& David F. Lopez, Motivated Skepticism: Use of Differential Decision Criteria for Preferred and Nonpreferred Conclusions, 63 J. Personality \& Soc. Psychol. 568 (1992). On motivated buyer behavior, see Michael LeWIS, The MONEy Culture 15 (1991); John O'Shaughnessy, Why People Buy 89 (1987).

45. The term agent is used here to include any person who makes investment decisions on behalf of another. This can include a broker with respect to a managed account, an outside investment advisor or advisory firm that employs a number of individual analysts, or an in-house advisor/analyst.

46. For a good discussion of the monitoring difficulties and the economic incentives that typical compensation arrangements create, see Josef Lakonishok et al., The Structure and Performance of the Money Management Industry, 1992 Brookings Papers on ECON. ACtivity: Microeconomics 339. The authors observe less effective monitoring of performance than one would expect given the competition within the market and the sums at stake. 
performance, ${ }^{47}$ bonuses and salary increases will often follow good performance; firing or other disciplinary action may well follow a series of subpar performances. A reputational incentive for positive performance is also created, since an agent's ability to attract future business or employment is dependent on his or her investment track record. This will be so even when compensation is based solely on the amount of assets under advisement.

An even more significant difference between individual and agent investing is the presence of oversight and accountability for investment decisions. The risk-taking behavior of investment agents is subject to monitoring by the beneficial owners of the portfolio, while the individual investor has no one to answer to but himself. Moreover, the agent is often employed by a larger organization and reports directly to one or more supervisors, who are presumably responsible for detecting and correcting any impropriety or foolishness. Inept or imprudent agents will likely be dismissed from the organization and eventually the industry before they can do too much harm. To be sure, some professional investors (financial officers for state and local governments and executives at savings and loan institutions during the period immediately after that industry's deregulation come to mind as examples) may be suspect because of structural lapses in marketplace discipline. ${ }^{48}$ But in general, accountability should assure a reasonably high level of sophistication and expertise among professional investment agents.

A desire for reputational and monetary gain, as well as accountability and expertise would thus predictably dampen excessive agent risk taking. While this may be so, a close look at the incentive structure suggests that the problem of excessive risk taking remains. Anecdotal evidence involving allegations of excessively risky activity at mutual

47. Curiously, the Investment Advisers Act of 1940 \$ 205, 15 U.S.C. $\$ 80 \mathrm{~b}-5$ (1994), restricts the payment of contingent fees based on performance, see Stephen M. Schultz, Performance Based Fees Under the Investment Advisers Act of 1940,39 Bus. LAw. 521, 521 (1984), at least for smaller accounts, Rule 205-3, 17 C.F.R. \$ 275.205-3 (1995) (exempting certain larger accounts).

48. Discipline frequently lapses with regard to state and local government financial officers because politics, rather than investment sophistication or success, determines who makes the investment decisions. See John C. Coffee, Jr., The Suitability Doctrine Revisited: Can Orange County Sue Its Broker for Recommending the Purchase of Unsuitable Securities for its Fund?, Nat'L L.J., Jan. 16,1995, at B4. Discipline lapsed for executives at savings and loan insitutions because they had the subsidization and perverse incentives of detailed federal regulation and insurance without accompanying effective supervision. See EDWARD J. KANE, The S\&L INSURANCE MESS: How Did It Happen? 5-7, 33-51 (1989); Lawrence J. White, The S\&L Debacle: Public Policy Lessons FOR BANK AND THRIFT REgULATION 117 (1991). When investment agents work on behalf of individual clients, problems of informational asymmetry may create circumstances where the monitoring is incomplete, allowing for some agents to survive notwithstanding a lack of expertise if they are skilled at maintaining client relationships. The discussion here merges into a consideration of how brokers can survive if their advice is suboptimal, the subject of the next section. 
funds, ${ }^{49}$ investment banks (such as Barings), ${ }^{50}$ and the finance departments of large multinational corporations (such as Procter \& Gamble and Gibson Greeting Cards) ${ }^{51}$ suggests that the problem does not simply arise when political forces interfere with an accountability standard for investment performance, as may have been the case with the Orange County scandal.

\section{a. The Agency Cost Problem}

We must therefore seek an explanation for why previously successful agents-those who have prospered in a competitive environment (and hence have a good bit of human capital at stake in their careers)might nonetheless assume excessive risk for their clients or employers. A common belief is that when an agent has acted imprudently, the principal is at fault for giving such responsibility to a person unable to exercise sufficient caution. The simple response to this argument lies in the contingent nature of both situational and individual risk preferences: ${ }^{.2}$ both people and circumstances change over time. The fact that an agent showed some dispositional tendency toward prudence at one career level (or under one set of circumstances) is probative of how he or she will act in the future, but by no means dispositive..$^{53}$

Precisely because individual agent performance is measured periodically against peers and against general market indices, fear of lagging behind the competition can become a dominating motivator. Loss framing readily ensues. A string of losses can cause the agent to assume more risk simply to get back to even, especially if failure to do so might result in termination and severe repntational penalty. This situation is much like the "last period" incentives faced by managers of companies on the brink of insolvency. ${ }^{54}$ They are willing to do quite a bit to keep their jobs.

49. See Leslie Wayne, Investors Lose Money in "Safe" Funds, N.Y. TIMEs, Sept. 28, 1994, at D1; Exchange Act Release No. 7,153, [1995 Transfer Binder] Fed. Sec. L. Rep. (CCH) I 85,612, at 86,494 (Mar. 29, 1995).

50. Barings, a large British investment bank, lost more than $\$ 1$ billion and was eventually sold as a result of excessively risky trading by one of its young traders. See Saul Hansell, The Collapse of Barings: For Rogue Traders, Yet Another Victim, N.Y. TIMEs, Feb. 28, 1995, at Cl; see also Sheila Bair, Lessons from the Barings Collapse, 64 Ford. L. Rev. 1 (1995).

51. See supra note 2.

52. See James G. March \& Zur Shapira, Variable Risk Preferences and the Focus of Attention, 99 Psychol. Rev. 172 (1992) (reporting empirical findings that level of risk taking is responsive to risk taker's changing fortunes).

53. As noted in text accompanying supra notes $35-44$, in explaining or predicting behavior people tend to overweight their impressions of stable dispositions and underrate factors that either alter or override this disposition.

54. For both an explanation and evidence for the tendency of mutual fund managers to adjust their risk preferences upward when they fear lagging behind their peers, see Keith C. Brown et al., Of Toumaments and Temptations: An Analysis of Managerial Incentives in the Mutual Fund Industry, 
It does not take fear of failure, however, to adjust risk preference upward. Over time, it is likely that the successful investment agent will gradually move ahead his or her target expectation level, the tipping point between risk-seeking and risk-averse behavior. ${ }^{55} \mathrm{~A}$ higher level of performance becomes necessary to maintain the acquired professional self-image, and it becomes easier to fall into a loss frame. Even the perception that the agent's peers may be a step ahead in the use of some new financial products or technology may cause the agent to view a choice of whether to invest in those products or technology as the avoidance of loss rather than the pursuit of gains. Numerous financial economists have noted the surprisingly high degree of "herding" in the behavior of professional investors. ${ }^{56}$ This behavior is hardly surprising in a competitive environment in which relative performance is the dominating measure of success and failure. The choice by some agents to pursue an investment medium (derivatives, for example) can trigger a chain of conforming behaviors based on the perhaps illusory assumption that their peers have done the homework even if they have not. Economists call these behaviors informational cascades; psychologists refer to the phenomenon as the process of social proof. ${ }^{57}$ Under either label, individual diligence is relaxed, though not consciously.

51 J. FIN. 85 (1996). On the last period problem facing corporate managers, see Jennifer H. Arlen \& William J. Carney, Vicarious Liability for Fraud on Securities Markets: Theory and Evidence, 1992 U. LL. L. REv. 691, 702-03 ; Reinier H. Kraakman, Corporate Liability Strategies and the Costs of Legal Controls, 93 YALE LJ. 857, 866 n.25 (1985); Susan Rose-Ackerman, Risk Taking and Ruin: Bankruptcy and Investment Choice, 20 J. LEGAL STUD. 277 (1991).

55. There can be little doubt that wealth is a powerful motivator in the culture of investment management: money managers and traders inhabit communities that include some of the world's highest paid professionals. To the extent that there is any asymmetry between the compensation associated with gains and losses (i.e., direct or indirect participation in gains, with no penalty for losses), the natural incentive would be to take more risk than if one's own money were on the line. This, of course, is a familiar moral hazard problem. More likely, however, there is a deterrent to taking too much risk embedded in the intense form of performance monitoring that exists in many investment settings.

56. Most of the explanations are informational rathcr than purely in terms of agency costs. E.g., Kenneth A. Froot et al., Herd on the Street: Informational Inefficiencies in a Market with Short Term Speculation, 47 J. FIN. 1461 (1992); David S. Scharfstein \& Jeremy C. Stein, Herd Behavior and Investment, 80 AM. EcoN. REv. 465 (1990); Brent Trueman, Analyst Forecasts and Herding Behavior, 7 Rev. FIN. STUd. 97 (1994).

57. The role of social proof in consumer frauds and swindles is emphasized in LEFF, supra note 16 , at 81 . On the economics of information cascades-i.e., the idea that one rational actor will make some choice by observing the behavior of another who might have superior information, and then will be observed by others and so on-see Sushil Bikhchandani et al., A Theory of Fads, Fashion, Custom and Cultural Change as Informational Cascades, 100 J. PoL. Econ. 992 (1992); Ivo Welch, Sequential Sales, Leaming, and Cascades, 47 J. Fn. 695 (1992). On social proof in the setting of financial markets, see Michael Klausner, Sociological Theory and the Behavior of Financial Markets, in 2 THE Social Dynamics of Financlal Markets 57 (Patricia A. Adler \& Peter Adler eds., 1984) ("The behavior of financial markets is very much a social phenomenon. People's decisions to buy, hold, or sell securities are greatly influenced by what others are saying or doing with respect to the financial markets."). 
Excessive self-confidence is also likely to affect agent behavior. As noted earlier, experts are at least as likely as amateurs to suffer from overoptimism and the illusion of control. In fact, their personal stake in the business of buying or selling securities makes it all the more important that they develop images of themselves as unusually competent and talented. The ability of agents taking excessive risk to manage professional anxiety, as well as to impress others, depends on this subtle form of self-deception. They will be reluctant to admit their mistakes (to themselves or to others), and hence may be particularly prone to compound their errors by overcommitting to a risky course of action. With larger portfolios under management, moreover, a considerable number of successes will be available from which to extract bias-confirming messages; losses can readily be rationalized by reference to the vagaries of market forces or the foolishness of firm colleagues. Agents, like individual investors, may be tempted to assume increasing levels of risk once they perceive themselves to be on something of a "hot streak." This is a classic form of hubris.

\section{b. Accountability: Why Supervision Can't Eliminate Excessive Risk Taking}

Accountability, however, should act as a counterweight to the foregoing tendencies. Assuming that professional investment agents are likely to exhibit biases toward risk taking, monitoring or oversight might be presumed to lessen this tendency. Accountability can affect agent behavior in two ways. Structurally, it may prevent a single agent from implementing an imprudent imvestment choice simply by limiting the opportunities to misbehave. Cognitively, it may lead to better judgment. The literature on decision theory suggests that a sense of accountability improves decision making, at least prior to committing to a particular choice. ${ }^{99}$

58. See Hirshleifer et al., supra note 36 , at 1686 (discussing "hubris" influence); see also DREMAN, supra note 17, at $98-100$ (discussing experts' inability to gauge own analytical ability). The court's observation in West Virginia v. Morgan Stanley \& Co., 459 S.E.2d 906, 917 (W. Va. 1995), may be apt: "Like so many other enthusiastic and ambitious persons before them, [the investors] tended to confuse profits in a bull market with intelligence."

59. See, e.g., Itamar Simonson \& Peter Nye, The Effect of Accountability on Susceptibility to Decision Errors, 51 Organizational Behav. \& Hum. Decision Processes 416 (1992) (examining conditions under which accountability is likely to improve performance in judgment and decision making tasks); Philip E. Tetlock et al., Social and Cognitive Strategies for Coping With Accountability: Conformity, Complexity and Bolstering, 57 J. Personality \& Soc. Psychol. 632 (1989) (reporting study showing that people unconstrained by past commitments will be motivated to complex, selfcritical thinking when made accountable to those whose views are unknown); Philip E. Tetlock \& Jae $11 \mathrm{Kim}$, Accountability and Judgment Processes in a Personality Prediction Task, 52 J. Personality \& Soc. Psychol. 700 (1987) (reporting study showing accountability caused subjects to process information in more complex ways). 
Yet full accountability is an illusory ideal. As with any internal control system, firms must inevitably undertake a cost-benefit analysis in deciding how much monitoring to implement. For example, a large investment banking firm could structure its computerized trading systems to require that all authorized trades be routed through a common facility before being transmitted externally. Real-time data generation could continuously test for risk exposure and alert monitors when it exceeds certain pre-arranged risk parameters. The monitors could then prevent the trade or at least immediately confront the trader. Such an internal control system would be extremely expensive, however. Even assuming such a system could be cost-justified at a large institutional firm, ${ }^{60}$ it would be impracticable in smaller settings like bank trust departments, investment advisory firms, and corporate treasurers' offices. Beyond this cost barrier lies an inherent problem of expertise. Successful monitoring requires that monitors possess the skill and experience to make quick judgments about the risk characteristics of the investments they are overseeing. People with enough talent to assess risk well will be more valuable as traders than as monitors. Reallocating that talent to a monitoring function would be very expensive.

Even if these problems could be overcome, many firms might still opt not to conduct such intense oversight. Contemporary principles of business management emphasize the need to promote a sense of autonomy, trust, and freedom among key employees. No employee likes to work under scrutiny, and people with apparent skill at investing are likely to resent and resist working in an environment in which they are constrained by the short leash that oversight entails. Firms that impose controls more stringent than the norm risk losing their best traders and analysts to competitors. A firm that has too comprehensive a system of monitoring and supervision may well find the remaining employees disheartened and unwilling to take even productive risks. ${ }^{61}$

\section{c. Breakdowns in the Accountability-Autonomy Equilibrium}

For all these reasons, most firms employing investment agents opt for a balance between oversight and autonomy, relying primarily on performance-based compensation contracts and reputational incentives to keep agents' interests aligned with those of the firm and using traditional "pyramidal" modes of supervision to check for aberrant abuses. While this structure may be efficient on average, breakdowns are inevitable, and excessive risk taking will sometimes occur.

60. In fact, quite detailed computer-based monitoring systems are already in use at the largest firms. Kurt Eichenwald, Learning the Hard Way How to Monitor Traders, N.Y. Times, Mar. 9, 1995, at D1.

61. See Rose, supra note 8, at 540-41 (discussing the effects of elose monitoring on behavior). 
First, in most hierarchies, the supervisor is also a line officer who is very busy with other tasks and whose compensation is based at least in part on the performance of his or her subordinates. As a result, the supervisor will face some of the same risk-inducing pressures, such as loss framing, faced by the subordinate. Moreover, the fact that the supervisor has hired (or simply chosen not to dismiss) the employee motivates the supervisor to bolster his or her judgment of the employee's performance. ${ }^{2}$ The supervisor will therefore perceive impropriety by subordinates more slowly than would a more objective observer. And the superficial appearance of normalcy that even rogue traders may be able to maintain creates a strong bias against vigilance for deeper problems. ${ }^{63}$ In sum, supervisors will often neglect danger signs that look vivid in hindsight.

Second, in traditional hierarchies, serious gaps of expertise can arise. Supervisors may not have the ability to master the risk characteristics of the investments in which each subordinate is involved, especially when those investments involve complex and innovative financial products and technology. ${ }^{64}$ The element of seniority, or experience gained under some earlier, different set of environmental influences, will often make learning all the more difficult. Yet few successful supervisors will readily admit to themselves, much less to others, that they are seriously behind on the learning curve and therefore unable to supervise their subordinates effectively. Rather, many will practice their own form of self-deception-an illusion of control-that buffers the anxiety that might otherwise occur, assuming a false confidence in their awareness and understanding of subordinate activities.

Finally, supervisors in traditional hierarchies may choose to minimize their monitoring beyond the bottom line of short-term perform-

62. See supra note 39. This cognitive bias may have played a role in Kidder Peabody's failure to prevent the trading scandal allegedly generated by Joseph Jett. For an interesting review of the Kidder Peabody scandal, see Alex M. Freedman \& Laurie P. Cohen, How a Kidder Trader Stumbled Upward Before Scandal Struck, WALL ST. J., June 3, 1994, at A1.

63. See Harold L. Wilensky, Organizational lNtelligence: Knowledge and Policy IN GOVERNMENT AND lNDUSTRY 91-92 (1967) (arguing that a "trust in conventional arrangement" and belief in "routine pieces of paper" prevented dealers from suspecting Tino De Angelis' salad-oil swindle in 1957-63). This mirrors the problem inherent when anyone "too close" to a situation is asked to spot trouble. See also Donald C. Langevoort, Where Were the Lawyers? A Behavioral Inquiry into Lawyers' Responsibility for Clients' Fraud, 46 VAND. L. REv. 75, 95, 98-106 (1993) (using social congnition literature to explore this question in the context of attorneys' ability to spot client fraud). The tendency to rely on social proof compounds this problem: the fact that no one else is alarmed is taken as reason to assume that there is no problem. See Jefreey Pfeffer, Managing WITH POWER 207-13 (1992) ("Having a lot of people around doing nothing in such a situation has two effects-first, it diffuses responsibility ...; second, ... the social information suggests that doing nothing is the appropriate and socially acceptable thing to do.").

64. See Hu, supra note 41 , at 1493 (noting that modem financial science "draws heavily on sophisticated quantitative knowledge that emerged subsequent to the ascendancy of many of today's senior bank managers"). 
ance. As noted above, micromanaging the employee's risk decisions, even if possible, no doubt chills what might otherwise be a profitably aggressive course of action. ${ }^{65}$ Consequently, many supervisors, consciously or not, do not want to know precisely how their subordinates achieve their results. As long as the agent's bottom line is profitable, there is little imperative to discover how those results were achieved. Focusing on the bottom line also facilitates the denial of either moral or legal complicity should severe problems be uncovered. ${ }^{66}$

For all these reasons, investment agents in securities firms are likely to possess a substantial freedom to take risks, often without accountability for much more than whatever performance measure the firm employs. ${ }^{67}$ Just as there are few constraints on individual investor risk taking, accountability will not serve as a complete structural or cognitive check on risk-taking agents.

This discussion also helps us deal with a separate point: the tendency in litigation over institutional sales to seek to place blame on the institutional buyer for "allowing" its agent to take too much risk. Although in some cases such blame is warranted, the dangers of hindsight bias $^{68}$ are severe here. An agent's imprudent investment choice should not necessarily force the conclusion that the institution should have concluded earlier that the agent was by disposition unqualified to be placed in a position of unsupervised autonomy. We should not, then, too readily conclude that an institution's controls were deficient simply because an agent's excessive risk taking was not prevented ex ante.

\section{B. Stockbrokers and Customer Risk}

Having identified the principal factors that can skew the investment decision maker's attitudes toward risk, I turn now to the stockbroker. The broker's economic self-interest is in generating the maximum possible amount of customer trading, since brokerage firm compensation from retail activities comes largely through the commissions and mark-

65. See supra note 61 and accompanying text.

66. See Jack Katz, Concerted Ignorance: The Social Construction of Cover-up, 8 URB. LIFE 295, 297 (1979) (discussing insulation of individual from group culpability that can result from concerted ignorance); see also John C. Coffee, Jr., Beyond the Shut-Eyed Sentry: Toward a Theoretical View of Corporate Misconduct and an Effective Legal Response, 63 VA. L. REv. 1099, 1107 (1977) (discussing similar observed phenomenon in corporate hierarchies of directors acting as "shut-eyed sentries"-deliberately looking away from management operations in order to avoid witnessing misconduct).

67. It is also possible that agents will systematically underestimate the risk of being held accountable when motivated to act in a questionable fashion.

68. See supra note 4. Particular dangers of the hindsight bias in business settings are noted in Hal R. Arkes \& Cindy A. Schipani, Medical Malpractice v. the Business Judgment Rule: Differences in Hindsight Bias, 73 OR. L. REv. 587, 621-23 (1994). 
ups attached to each transaction. ${ }^{69}$ Most registered representatives today are compensated under a system heavily weighted toward commissions, as opposed to straight salary. ${ }^{70}$ Commissions and mark-ups will vary depending on the nature of the security in question. In general, the level of broker compensation is fairly closely correlated to the expected difficulty of selling that security, which in turn is correlated with the security's level of risk. ${ }^{71}$

Securities are often riskier than other uses of discretionary funds. In many ways, then, the broker's economic goal is usually to instill in the customer an increased willingness to take investment risk. For some customers, this involves persuading them to forgo consumption, or to transfer money from bank accounts or conventional insurance products, in order to invest in securities in the first place. For others, the broker's role involves focusing the customer on specific investments rather than others or turning over the portfolio in search of increasing levels of return. In this Section, I shall consider both opportunity and motive in an effort to understand the incentive structure for brokers' systematic complicity in what would seem to be objectively unwise investments.

69. This is subject to some change today, as brokerage firms try harder to establish trusting relationships with customers in order to gain a competitive advantage in marketing a wide variety of financial services products such as credit cards, loans, and insurance. However, this development, although not insignificant to the discussion that follows, is not yet sufficiently pervasive to cast doubt on the dominating significance of commissions and mark-ups in the industry's incentive structure.

70. For obvious reasons, this has long been a controversial feature of the industry. For discussions of the conflict of interest that the commission system creates, see NORMAN S. POSER, BROKER-DEALER LAW AND REGULATION § 1.2 (1995) (argning that because brokers are generally compensated by volume-based commission, they face a conflict of interest in giving advice to and trading on behalf of customers); Martin Mayer, Broker-Dealer Firms, in ABuSE ON WaLt. STrEet: CONFlicts OF lNTEREST IN THE SECuRITIES MARKETS 433, 463-68 (The Twentieth Century Fund ed., 1980) (discussing ability of brokers compensated by commissions to make money by generating customer trades, regardless of whether customer's interests are served). Nonetheless, anecdotal evidence suggests that investors are less sensitive to the wage structure of the brokerage industry than they should be. See, e.g., Srully Blotnick, Winning: The Psychology of Successful lNVESTING 64-67 (1979) (noting conflicting interests of brokers ("buy often") and investors ("buy low, sell high")). Recently, the SEC and others have urged a shift in the compensation system, and some firms (including Merrill Lynch) have indicated some movement away from heavy commission emphasis. Report of the Committce on Compensation Practices, Executive Summary, reprinted in [1995 Transfer Binder] Fed. Sec. L. Rep. (CCH) I 85,614 (Apr. 10, 1995). Still, so long as firm profitability depends on the volume of trading, it is hard to see how individual brokers will ever be immune from heavy pressure to sell.

71. More precisely, the compensation will be based on the firm's expected profitability from the particular product. For example, in-house products, being more profltable, will be pushed heavily. In general, however, one can safely predict that higher-risk products will require both enhanced profitability to the flrm and increased sales promotion. Above-average commissions are also necessary when brokers will have to devote more time and effort to learning the details of a particular investment than they would to other products. 


\section{Opportunity and the Broker's Role: Influence Techniques}

This Article does not mean to imply that the brokerage function is purely, or even mostly, opportunistic. Brokers play a legitimate role in helping their customers to identify and understand their investment needs and objectives, and to identify securities to build a portfolio meeting these needs and objectives. Even the most sophisticated investors require assistance in identifying and gaining information about the extraordinarily large and constantly changing set of investment options available in the market.

Stockbrokers play a useful function in both retail and institutional sales in transmitting accessible and customized information about a very complex financial world. As significant and useful as this function may be, however, it is naive to believe that providing information is all or even most of what brokers do. ${ }^{72}$ Economists have frequently poiuted out that structuring an efficient portfolio is not all that difficult, involving primarily a buy-and-hold (i.e., inactive) strategy with investments diversified among a set of individual securities or mutual funds. As noted earlier, it has never been established that the sort of investment information offered by the brokerage industry is particularly profitable for its customers, in the sense of systematically generating aboveaverage returns net of expenses. ${ }^{73}$ The commission-based structure of stockbroker compensation, the handsome sums paid to high-producing brokers, and the training brokers receive indicate that a stockbroker is as much a salesperson as a transmitter of imformation. Generally, stimulating customer demand for a particular security involves prompting the assumption of additional levels of risk in pursuit of a desired return and then offering a specific investment recommendation. ${ }^{74}$

72. Because it is an empirical question, we cannot predict from theory alone what percentage of broker-customer sales interactions is purely informational, and what percentage moves on toward the manipulative or persuasive. To be sure, many such interactions are perfectly legitimate and ethical.

73. Numerous academic studies-both of brokerage firm recommendations and of the performance of institutional investment managers generally-give reason to doubt that research systematically pays off for investors. E.g., MALK1EL, supra note 14, at 165-93; Hemang Desai \& Prem C. Jain, An Analysis of the Recommendations of the "Superstar" Money Managers at Barron's Annual Roundiable, $50 \mathrm{~J}$. FiN. 1257 (1995) (finding no abnormal retums based on the recommendations of "superstar" managers); Clinton M. Bidwell, III, How Good Is Institutional Research?, J. Portfolio MGMT., Winter 1977, at 26 ("not very"). This doubt is especially problematic given the commissions that investors pay for such research. See Stout, supra note 13, at 670-77. A more charitable view of the value of advice, though by no means purporting to resolve the debate in the security industry's favor, is Kent L. Womack, Do Brokerage Analysts' Recommendations Have Investment Value?, 51 J. Fin. 137 (1996).

74. A fact of life for stockbrokers is the need to prospect constantly for new customers. Especially for junior brokers, this must often be done with strangers in "cold calls." See, e.g., LEROY Gross, ART of SElling INTANGibles 81-120 (2d ed., 1988) (describing need to, and strategies and sources for, finding quality prospects); Carol J. Loomis, Have You Been Cold-Called?, ForTuNE, Dec. 16, 1991 at 109 ("On Wall Street, unfortunately, [cold calls] are considered a raw necessity."); 
How does a stockbroker stimulate demand for a particular security besides passing on accurate information about it? One way, of course, is to lie. Feeding a customer misinformation about either expected risk or expected return will skew mvestment decisions, provided the customer believes the information. In general, of course, such material misrepresentations are unlawful; the only interesting issues here, therefore, are: (1) whether there are natural reputational checks that make knowing misrepresentations an aberrant form of behavior by brokers, and, (2) why, given the recognizable conflicts of interest, sophisticated investors would readily rely on brokers' factual representations as to risk and return. Both topics are considered below.

This latter question is related to the fundamental strategic difficulty facing any sales professional, whether honest or corrupt: how, given the limited time available, to overcome customer suspicion and build trust so that representations will be believed, and recommendations acted upon.$^{75}$ Many prospects will be resistant to even the most effective sales pitches for either dispositional or situational reasons. However, successful techniques are well known in the industry, and are worth considering in some detail. In brief, these techniques involve predicting or discovering the needs and objectives that the customer brings to the interaction, building a sales pitch around them, countering objections, and getting a prompt "close."

see generally Martin D. ShafiRoff \& Robert L. Shook, Successful Telephone Selling in THE 90's 109 (1990) (discussing telephone solicitation in many selling contexts). For some junior brokers, this is almost all they do. Thus, much of their time is spent with specially designed telephone lists calling one prospect after another, hoping for some sales amidst a heavy majority of rejections. In the industry, a sales rate of $10 \%$ is good. See SALER, supra note 5, at 36 . In 1995, the NASD proposed a rule that would involve bringing telemarketing scripts within existing regulatory controls over advertisements and sales literature. See NASD Proposes Revised Definitions of Advertising and Sales Literature, 27 SEc. REG. \& L REP. (BNA) 908, 908-09 (June 16, 1995); see also ICI Opposes NASD Proposal on Sales Literature Approval, 27 SEC. REG. \& L. REP (BNA) 1303 (Aug. 4, 1995) (reporting ICI opposition to the NASD proposal which would require registered principals to obtain preapproval for sales materials).

75. Most potential customers approach a sales interaction suspicious of the salesperson's motives and tactics. The key to effective selhing is to overcome this initial mistrust. See Steven P. Brown, Use of Closed Infiuence Tactics by Salespeople: Incidence and Buyer Attributions, J. Pers. SElling \& SALES MGMT., Fall 1990, at 17, 18 (discussing tendency of customers to attribute improper motives to salespeople's behavior because salespeople stand to gain in sales interactions); see also Brent G. Goff et al., Cues to Customer Susceptibility to Salesperson Influence: Implications for Adaptive Retail Selling, J. Pers. Selling \& SAles MGMT., Spring 1994, at 25, 27 (discussing trust-building techniques for salespersons). From an ethical perspective, this raises an interesting paradox: because trust is an important condition to a sale, absent a long-standing relationship by which a true measure of trust can be generated and tested, salespeople must effectively project trustworthiness via illusions, which implicitly belie the trust. Guy Oakes, The Sales Process and the Paradoxes of Trust, 9 J. Bus. ETHICs 671 (1990). 


\section{a. "Act Now"}

As we have seen, customer needs and objectives may or may not be simply financial. No doubt many potential customers are primed to succumb to straightforward promises of quick profits. Projecting an aura of success, ${ }^{76}$ the broker conveys the message that the customer is one of a favored few selected to receive a special investment opportunity. This strategy appeals to both the customer's greed and his or her ego. ${ }^{77}$ Sometimes the broker hints that favorable returns are almost guaranteed, either because there is inside information, or the market for the stock is controlled. ${ }^{78}$

The broker's sales presentation emphasizes the need to act now, an influence technique referred to in the literature as the principle of scarcity. ${ }^{79}$ Customers are led to believe that unless they act promptly, the opportunity will be lost. The implication is that other investors are buying heavily, and there will soon be nothing left at this price. Predictable objections (such as "I have to talk to my husband/wife," "I don't have the money right now," "I want to think about it") all have prepared responses, often scripted. ${ }^{80}$ The broker carefully structures the presentation of the investment opportunity in what is essentially a loss frame: if the customer passes up the opportunity, he or she will suffer

76. Securities salespeople are taught to dress and act "successful" regardless of their actual circumstances. This conveys the impression that the broker has previously given successful advice and has a reputation to protect. In addition, projecting success, at least when selling to wealthy or successful prospects, creates a social bonding. All of these are well-known influcnce techniques. See, e.g., Robert B. Cialdini, Influence: Science and Practice I84-87 (3d ed. 1993) (discussing effects of trappings of authority, including business suit, on observers). Anccdotally, some marginal securities firms have chosen their names to create illusions of success: one former broker in the penny stock industry suggests that "European" sounding names work best. See LEwis, supra note 44, at 27.

77. Amusingly, one stockbroker notes that this technique works particularly well with lawyers. Loomis, supra note 74, at 114 .

78. An excellent survey of the kinds of scripted representations used in the penny stock market is Joseph I. Goldstein et al., An Investment Masquerade: A Descriptive Overview of Penny Stock Fraud and The Federal Securities Laws, 47 Bus. LAw. 773, 786-90 (1992); see also Jessica Sommar, Dial and Rile: Cold Calls Anger Public, Legislators, Investment Dealens' DiG., Nov, 11, 1991, at 16, 19 (discussing cold-calling scripts used by well-established firms). For a case involving scripted misrepresentations, see SEC v. Hasho, 784 F. Supp. 1059, I066 n.5 (S.D.N.Y. 1992).

79. See Cialdini, supra note 76 , at 194-219.

80. Some salespeople are almost bullying in their responses. Husbands who say they have to talk to their wives have their manhood questioned (e.g." "Sir, do you not make the decisions in your family?"). See Goldstein et al., supra note 78, at 789. Those who delay are called fools: one broker reportedly demanded that a customer refusing to buy write down, "[T]oday 1 lost a fortune." In re Engelman, Exchange Act Release No. 34-35729, 59 SEC Docket (CCH) 758, 76 I (May 18, 1995). Why such bullying tactics might work with some people is addressed below. As a comparison, a recent survey cbaracterized investment marketing tactics dirccted specifically at women as the "soft sell," with emphasis on loss framing. Nancy A. Jeffrey, Wall Street's Soft Sell Lures Women Investors, WALL ST. J., July 28, 1995, at C1. Jeffrey notes that these attempts to educate women on the need to invest wisely are in marked contrast to the traditionally high-pressure tactics uscd to persuade male clients. Id. 
financial loss in comparison to other investors, and regret will ensue. The anticipatory regret provokes anxiety ${ }^{81}$ about the loss of self-esteem if a good opportunity is "given" away to other investors, who may flaunt their increased wealth and status and ridicule the "losers" who never had or never seized the opportunity.

Why would any reasonably experienced investor ever fall for this? Many will not. Like Ulysses with the Sirens, ${ }^{82}$ many will adopt a strict rule of not even listening to the broker's blandishments in the first place and will certainly not get into a discussion about them. Sales pitches fail more often than succeed. But if the broker can somehow prompt a desire for the security, in many situations, the customer will shift his or her decisional process away from vigilance toward rationalizing the investment activity. ${ }^{83}$

\section{b. Credibility and Knowledge Disparity}

Once the customer is primed to want to make the investment, the savvy broker explicitly or implicitly supplies a plausibility structure from which to overcome doubts. Here is where the cognitive illusions referred to earlier, such as herding, become more compelling. Doubts about broker credibility, if not previously countered, can be deflected by invoking the apparent reputation of the firm or the broker. An image of prior successes for the broker or firm suggests that success will happen one more time for the customer. At the very least, the customer may reason that the firm or broker would not put their reputation at risk by cheating him or her. Once the broker can engage the customer in a discussion about the security, the game is almost surely won. The broker can then easily exploit the customer's lack of information and expertise, insisting that the customer explain why, contrary to the recommendation, the investment is not a good one-something few will be able to do confidently. Most people, especially those with some degree of professional success, are unwilling to expose their own inferior

81. See Richard P. Larrick, Motivational Factors in Decision Theories: The Role of SelfProtection, 113 Psychol. Bull. 440, 445-47 (1993) (discussing the impact of "anticipatory regret" on decision making under uncertainty); $c f$. Richard P. Larrick \& Terry L. Boles, Avoiding Regret in Decisions with Feedback: A Negotiation Example, 63 Organizational Behav. \& Hum. Decision PROCESSES 87, 88-89 (1995) (discussing post-decision avoidance of information that may trigger regret).

82. In Greek mythology, the adventurer Ulysses was said to have ordered his shipmates to tie him to the mast of his ship as it passed the island of the Sirens, because the Sirens' singing was so beautiful that no man could resist jumping overboard to swim to them. JON ELSTER, ULYSSES AND THE SIRENS: STUDIES IN RATIONALITY AND IRRATIONALITY vii, 36 (1979). This allusion has been used to describe a variety of behaviors where people adopt a rule of action that they recognize may be inconsistent with their best interests because they do not trust themseIves to act prudently. See generally Scott, supra note Il (arguing that individuals rationally impose constraints on their freedom of choice in pursuing a strategy of making better decisions).

83. This is a classic form of motivated reasoning. See supra note 44 and accompanying text. 
knowledge to others, ${ }^{84}$ and will subconsciously avoid such a prospect simply by agreeing with the broker. At this point, it is time for the broker to move to close.

\section{c. Anxiety}

Apart from all this, investors are motivated to trust stockbrokers. Investing generates anxiety. As noted above, it is commonplace to view current investment choices in an overall loss frame: fail to invest wisely now, and you will suffer an erosion in financial and reputational capital and a potentially diminished standard of living compared to peers who make the right choices. ${ }^{85}$ Broker sales pitches and firm advertising seize on this anxiety, often hitting hot-button concerns such as whether sufficient money will be earned to guard against sudden unemployment or send a child to college. This strategy may both prompt a greater willingness to take risk and exacerbate the sense of being overwhelmed by the uncertainty and range of information. A natural human response to this anxiety and anticipatory regret is to externalize the dilemma by seeking out someone to whom to transfer the responsibility. ${ }^{86}$

\section{d. Friendship}

Once the broker has established a relationship with the customer before making a particular sales pitch, other standard influence techniques become available. No doubt the most common is to offer the customer the appearance of friendship. Acting in a friendly demeanor (when coupled with appropriate dress) establishes a bond that can be readily exploited. ${ }^{87}$ Conventional social mores do not allow challenges to the credibility of information offered by a "friend." 88 Prospective buyers may even utilize their purchases as a way to gain favor with the broker, and thus enhance their own self-esteem. ${ }^{89}$ Anecdotally, people

84. See Langevoort, supra note 31 , at 879.

85. See supra notes $27-34,54-57$, and accompanying text.

86. See Blotnick, supra note 70, at 87-88; Shefrin \& Statman, supra note 34 , at 56-57.

87. See Cialdini, supra note 76, at 136-40; see also Harold J. LeavitT \& Homa Bahrami, Managerial Psychology: Managing Behavror in Organizations 142-47 (5th ed. 1988) (discussing different manipulation models); Sally F. Moore, Law and Social Change: The SemiAutonomous Social Field as an Appropriate Subject of Study, 7 LAW \& Soc'Y Rev. 719 (1973) (discussing commonality of "fictive friendships" in economic activity).

88. Robert Shiller makes an interesting point that efficient social learning is often thwarted by customs and manners: we will not learn efficiently from others about topics that are not subject to easy conversational protocols (including some financial matters). See Robert J. Shiller, Conversation, Information, and Herd Behavior, 85 AM. Econ. Rev. (PAPERS \& PROC.) 181, 184 (1995).

89. James G. March, A Primer on Decision Making: How Decisions Happen 213 (1994) (summarizing the bargain by referring to Dale Carnegie's sales philosophy, which in essence is, "If you will buy my pots and pans, I will give you respect and love."). Srully Blotnick notes that an unusually large number of brokerage customers have a strong desire to keep their brokers happy. BLoTNICK, supra note 70 , at $80-82$. 
often explain their purchase in terms of feeling sympathy for the salesperson. Brokers thus learn to spend time chatting with potentially valuable customers to establish a personal relationship. Similarly, brokers can attempt to take advantage of a customer's status needs, by creating a sense that only a "selected few" are permitted to have an account with a particular firm or broker. In this way, they can actually deter challenges to their credibility by issuing a subtle threat that the privilege will be withdrawn if the customer is insufficiently responsive. ${ }^{90}$ Indeed, like Charles Dickens' young Martin Chuzzlewit, people with a high need for status may have low resistance to influence simply because it would be unseemly and inconsistent with their self-image to challenge someone else of apparently good standing in the community.

Once a customer commits to a relationship with a particular broker, he or she becomes even more susceptible to influence. Quite apart from any status and friendship needs that are met by the relationship, the very fact that the customer has chosen to rely on a particular broker creates a strong incentive to justify that decision. The principle of cognitive dissonance makes plain that once committed, customers will resist the notion that they are being exploited. Entertaining suspicions of the broker would force customers to reconsider the initial choice. Thus, they are motivated to filter out information that might otherwise make them suspicious of the post-commitment sales pitch.91 ${ }^{91}$ Preferring instead to boIster their choice, customers are likely simply to observe or infer that the broker's other customers are not visibly troubled, and subconsciously to dismiss any reason for concern. Other customers, of course, may well be using the initial customer as the base for the same social proof, creating a circle of conformity.

\section{e. The Art of Institutional Sales}

The foregoing discussion assumes that the customer in question is a retail investor. One might expect the nature of the broker-customer interaction to differ when the customer is a professional investor acting as

90. The status-seeking behavior of brokerage customers is a fairly well-recognized phenomenon. See, e.g., Andrew E. Serwer, The Wacky Way the Wealthy Invest-And How to Do it Right, FortuNe, July 1, 1991, at 2I (noting a "predilection for prestige" among wealthy investors' choices of money managers). The New Era investment scandal, where investors readily bought inwith few questions asked-once very high status people were featured as investors, appears to have been an example of this. See Michael Lewis, Separating Rich People From Their Money, N.Y. TIMES MaG., June 18, 1995, at 18; Steve Secklow, Incredible Offer: A Big Charity Faces Tough New Questions about Its Financing, WALL Sr. J., May 15, 1995, at A1, A8.

91. This is certainly true of initial product decisions: people are more likely to state that they are satisfied with a product after deciding to purchase it. See Jack W. Brehm, Postdecision Changes in the Desirability of Alternatives, 52 J. Annormal \& Soc. Psychol. 384, 389 (1956); Donald Granberg \& Thad A. Brown, The Monty Hall Dilemma, 21 Personality \& Soc. Psychol. Bull. 711 (1995) (explaining irrational tendency to resist disconfirming new information). 
an agent for others. Institutional selling is itself an important professional art, and it is worth considering what influence techniques might work in this environment. ${ }^{92}$

Even in institutional settings, investors are likely to rely on factual misrepresentations once the credibility of the seller has been established. Time and resource constraints render independent verification of broker recommendations impracticable, and the broker's superior access to information encourages customer reliance. As with retail investors, the broker will commonly build his or her pitch around scarcity. The broker can establish credibility by invoking an established reputation or occasionally by manufacturing an appearance of established quality. Successful salespeople have been known to combine dress and demeanor, a fabricated list of well-known "other customers," and a tempting sales pitch to close transactions with very large accounts. As in the retail setting, an institutional bnyer's decision, including reliance on a stranger, can be rationalized where the temptation is strong enough. A buyer under severe pressure to meet a high performance standard will want very much to believe that a security recommended as having a high rate of return would indeed be a suitable addition to the portfolio. As the buyer's resistance diminishes, credibility tests are more easily satisfied. ${ }^{94}$

Loss framing is likely to be particularly effective in an institutional environment. As noted earlier, herding behavior by institutional investors suggests an understandable motivation to avoid falling behind the crowd. This instinct offers the salesperson an obvious opportunity to exploit the agent's insecurity. Sales presentations for new investment products such as derivatives can state or imply that peers at other companies or firms are moving quickly in the promoted direction, and that the buyer risks underperformance by not conforming promptly. In an

92. For discussions of salesperson influence on professional buyers, see, e.g., Thomas $V$. Bonoma \& Wesley J. Johnston, The Social Psychology of Industrial Buying and Selling, 7 INDus. MARKETING MGMT. 213 (1978) (suggesting that traditional assumptions about industrial buying behavior should be replaced by analysis derived from the social psychology of power and influcnce); Rosann L. Spiro \& William D. Perreault, Jr., Influence Use by Industrial Salesmen: Influence Strategy Mixes and Situational Determinants, 52 J. Bus. 435 (1979) (evaluating marketing strategies of industrial salespersons and factors determining their effectiveness).

93. The fabrication need not last long, beeause once some customer starts buying, that fact alone can be used truthfully with subsequent prospects. See Lewis, supra note 90, at 18. As noted above, social proof is a powerful force; people's tendeney to follow the behavior of others often leads to an informational cascade. This (along with an agency-cost explanation) helps explain herd behavior among professional investors. See supra notes 54-57 and accompanying text.

94. We might ask why principals and advisory firms would not seek out money managers who are more resistant to sales pitches. A possible explanation is that people who are dispositionally resistant are too rigid to be successful investment agents. The disposition to take risks and to react quickly to new opportunities (even if salespeople are involved) may be characteristic of the good agent, even though it carries with it the possibility of manipulation. 
environment in which new financial products and techniques are introduced rapidly, and old ones change constantly, a buyer's reticence can be made to seem potentially very costly.

As with the retail customer, subtle manipulation of an institutional investor's professional ego is also possible. Take, for example, a wellprepared broker who pitches an exotic, customized interest rate swap to a corporate treasurer. Even if the treasurer has a fair degree of financial sophistication, it is unlikely that her knowledge or understanding extends to such a unique product. Under these circumstances many potential buyers will resist displaying their ignorance. Indeed, early on in the conversation or course of dealing a savvy broker can subtly prompt the customer to inflate his expertise. Later on, the customer will be uncomfortable asking questions about the pitch or challenging the broker's representations in a way that would expose his or her lack of knowledge. The most direct way of resolving the dissonancedeflecting the ego threat-is to agree with the broker. This tactic can be particularly effective if the customer will have to display her ignorance in front of peers or coworkers. Since the central source of self-esteem for many people is their job, a broker often has much to work with when dealing with a professional investment purchaser.

Status concerns may also come into play. Although some institutional purchasers work for snfficiently high-status firms that brokers have little to offer them, many others, such as those working for smaller banks and thrift institutions or less well-known industrial corporations, desire an association with a well-known brokerage firm. ${ }^{95}$ One suspects that many savings and loan executives, for example, enhanced their selfesteem and status among local business people by joining the "team" of buyers Drexel Burnham put together to market its junk bonds. ${ }^{96}$

There are methods, therefore, to lower both retail and institutional customers' resistance to the sales pitch and create a desire for a particular investment, all subtly exploiting the moral hazard implicit in every principal-agent relationship. None of these requires that the compliant customer be unsophisticated (though he or she may be acting imprudently). Indeed, as we have seen, the customer's very possession of a degree of financial sophistication is manipulated in certam sales tech-

95. For an example of this effect, see LEwis, supra note 44, at 109 (recounting the story of a Minneapolis savings and loan executive who routinely followed the advice of her Salomon Brothers salesman because she felt like Salomon "knew what was going on in Washington").

96. Drexel's infamous "Predator's Ball"-an extravagant social event to which only its most elite customers were invited-no doubt played an important role in decreasing customer resistance to Drexel's sales pitches. See Connie Bruck, The Predator's Ball: The Junk-Bond Raiders AND THE MAN Who STAKEd THEM (1988). At some point, of course, using such lavish incentives to encourage investment agents to make particular securities purchases for their principals borders on commercial bribery. 
niques. Nor are customers who are effectively manipulated likely to realize this manipulation, given their strong need to view themselves as reasonable and responsible. Though their underlying motivations may actually be to reduce anxiety throngh status seeking or self-protective "herding," it would be inconsistent with the dominating-and highly functional - self-image to acknowledge this. Once again, the agent will take on more risk without consciously acknowledging the shift.

\section{Motive: The Role of Reputation, Long Term Relationships, and Learning from Experience}

To say that savvy or well-trained brokers have the opportunity to manipulate their customers into purchasing overly risky investments does not necessarily mean that they will do so frequently. Even disregarding personal and institutional ethical constraints-which hopefully have some significant power-they must perceive a reason to engage in such opportunistic behavior. To be sure, the commission or mark-up from an immediate sale creates a temptation that some brokers will be unable to resist. But brokerage firms claim, as I noted earlier, that rational brokers recognize that customers who believe they have been burned will quickly-and perhaps noisily-move their business elsewhere. Sometimes, customers will sue or seek arbitration, imposing additional, nontrivial costs. ${ }^{97}$ Brokers, therefore, have a dominating economic self-interest in keeping customers happy. Brokers argue that although manipulative behavior may be used in the selling process, it is only directed at getting customers to buy a quality product, one that will not later lead to dissatisfaction.

There is much to be said for this argument. Well-known texts on selling securities, such as LeRoy Gross' Art of Selling Intangibles ${ }^{98}$ which otherwise offers mildly inanipnlative suggestions for the stockbroker ${ }^{99}$-make it a central theme. In this Section, however, I will test

97. The costs of dispute resolution include not only the obvious, such as attomeys' fees and potential judgments or settlement costs, but also bad publicity and the possibility of regulatory intervention. Verdicts and arbitration awards against brokers are often publicized, even if the underlying factual matters are subject to a confidentiality agreement. The SEC and the NASD, moreover, have acted recently to publicize disciplinary and related information regarding individual brokers. Report on the Status of the Recommendations from the Large Firm Project Report, reprinted in [1994-1995 Transfer Binder] Fed. Sec. L. Rep. (CCH) II 85,432, at 85,741 (Oct. 12, 1994) (discussing, among other initiatives, creation and disclosure of a toll-free number to provide customers with information on firm and representative disciplinary history); Exchange Act Relcase No. 34-32568, 54 SEC Docket (CCH) 957 (July 1, 1993) (granting accelerated approval of proposed rule change relating to toll-free number).

98. Gross, supra note 74 .

99. Not surprisingly, books published by reputable publishers and authors on salesmanship never teach or condone trickery or significant manipulation. In many ways, one suspects, their primary role is to offer legitimacy to the art of selling. Nonetheless, even books like Gross' condone some measure of gamesmanship. Gross, for example, suggests that one way to get a luncheon 
the argument to see if there are predictable circumstances in which its persuasive power weakens. There are two possibilities to consider. One is that brokers will occasionally conclude that sufficient commissions will be earned before customers realize they have been pushed into an unwise investment, or that the realization can be postponed indefinitely. Here, a rational risk-return calculation indicates that deliberate broker cheating is an optimal strategy. The other possibility is that brokers will underestimate the risk associated with certain securities. They will then aggressively push the securities, convinced that they are of appropriate quality and unlikely to lead to customer dissatisfaction, when in fact identifiable risk characteristics are never disclosed to the customer. In this regard, I consider whether situations might arise where miscommunication or inaccurate internal estimation, such as perhaps the broker's own loss framing, leads the broker either to underappreciate objective risk factors or to rationalize customer manipulation.

\section{a. Cheating as an Occasionally Rational Strategy}

In some situations, a rational broker will be tempted to cheat notwithstanding the reputational checks noted above. At the risk of sounding cynical, opportunistic behavior toward a customer is rational whenever the expected return exceeds the potential loss of future income together with any reputational penalty and dispute resolution costs. Because both sums must be discounted to present value for comparison, cheating may be rational simply because of the time lag: the return will come rather quickly, while the losses-if they occur at allare likely to occur later in time, thus creating an intertemporal choice problem. ${ }^{100}$

A major variable affecting whether and when a rational calculus would dictate cheating is the expected customer response. The broker may believe that some customers will learn slowly and resist information indicating that they have been duped. Most people are fairly poor at learning from experience, especially if the lesson is not a flattering one. Feedback must be fairly immediate and unambiguous to overcome customers' resistance to admitting a mistake; in most brokerage settings, neither of these conditions is likely to be satisfied.

Imagine, for instance, a customer who has developed a relationship with a broker over the past year and followed ten recommendations. This well-trained broker never "guaranteed" any short-term results, instead stressing the high likelihood of positive returns. The broker also

appointment with a busy prospect is to call that person's secretary and simply leave a message confirming the lunch later in the week, and then arrive on schedule. Access will probably be granted. Id. at 116-17.

100. See supra note 42 and accompanying text. 
ensured that the customer felt significantly involved in the investment decision, that is, that the ultimate decision was the customer's. In these circumstances, behavioral considerations may conspire against any prompt realization of overreaching by the broker.

The first reason is motivational. Having committed to both the relationship with the broker and the particular transaction, the customer is motivated to bolster these decisions, finding it ego-threatening and shameful to conclude that he or she acted on bad advice. ${ }^{101}$ Such an inference might also threaten other significant needs-status or friendship, for example-that the investment account serves. The natural tendency, then, is to seek non-threatening explanations for the misfortune. ${ }^{102}$

Now consider the number of recommendations. Even if performance has been poor on average, simple chance dictates that some of the ten probably did well. Markets, after all, are volatile and unpredictable. Indeed, if the broker did a good job of selling even a fairly low-quality security, there can be a short-term price run-up simply because of the induced demand. ${ }^{103}$ So long as the customer was not on the tail end of the sales program, some positive feedback will occur. In addition, nearly all investments are open-ended: poor performance is seldom established conclusively, since a turnaround is always possible. Investors have a well-documented tendency to hold on to losing investments too long: ${ }^{104} \mathrm{~m}$ fact, some customers may view poor performance as an opportunity to escalate commitment by purchasing even more of the stock at a cheaper price.

The customer thus has ample means to rationalize short-run poor performance of an individual investment as something other than the product of bad advice and bad decisions. Blaming external circumstances such as timing, market mfluences, or luck is also useful. Not until repeated, sustained losses gradually eliminate alternative explanations, or an investment catastrophe presents an overwhelming circum-

101. Arthur Leff uses a similar argument to explain the success of many swindles that take time to play out. LEFF, supra note 16 , at 84-87.

102. For a good exploration of excuse-making that serves a self-esteem bolstering role, see C.R. SNyder et al., Excuses: Masquerades IN Search of Grace 31-33 (1983). In the institutional setting, a broker might predict that the individual trader who made the purchase dccision has an extra motivation to either rationalize away or cover up the harm: the fear of being blamed by his or her principal. Complaining loudly about being taken advantage of by a broker is a weak excuse unlikely to aid the trader's reputation or career prospects.

103. This may occur if the market is inefficient due either to thin trading or to price movements unrelated to fundamental value caused by the presence of noise traders sucb as uninformed investors. See supra note 14. Indeed, one technique used in the penny stock market is to sell securities to investors and then manipulate the market so that the price increases for a short period. This positive feedback can readily "hook" the customer.

104. See, e.g., Hersh Shefrin \& Meir Statman, The Disposition to Sell Winners Too Early and Ride Losers Too Long: Theory and Evidence, 40 J. FIN. 777, 785-88 (1985). 
stantial case, will customers finally acknowledge that bad investment decisions produced their losses. At this point, they can blame either themselves or their brokers. Only then will large numbers, particularly those with healthy levels of self-esteem ${ }^{105}$-blame their brokers, terminate the account, and (if they are angry enough and sufficient sums are at stake) bring suit.

If this typifies investor reasoning, a rational broker may justifiably decide to cheat long enough to make immediate returns. Confident brokers may decide that they can postpone the realization process indefinitely through a combination of charm, rationalizations, a handful of winners, and selectively pointed reminders of the recommendations that the customer didn't follow that made lots of money. ${ }^{106}$ And, of course, there always exists the opportunity for new customers. ${ }^{107}$ Thus, it is not implausible that a broker will conclude that a strategy of some customer manipulation will have a positive payoff. ${ }^{108}$

\section{b. The Broker's Own Frame}

Brokers are likely to mirror the behavior of institutional investment agents because they face the same competition, compensation, and status

105. Not surprisingly, the same self-esteem needs that might have thwarted realization of the harm will exacerbate the need to blame someone else once the presence of harm is clear.

106. BLotNICK, supra note 70 , at $90-92$ (discussing broker strategy of "inducing selective amnesia" by talking only about results of predictions that have come true).

107. Simple demographics promise that new "victims" will always be forthcoming. See Stout, supra note 13, at 639-40. However, considering the competitive nature of the brokerage industry, an endless supply of prospects probably gives a broker insufficient reason to be inattentive toward existing customers.

108. Sadly enough, the risk/retum calculation can skew the broker's decision even more severely toward opportunism. In recent years, much regulatory attention has been directed at the sale of illiquid and risky limited partnerships, sometimes through a combination of misrepresentations and half-truths, sometimes simply through bad advice. Prudential Securities paid more than $\$ 1$ billion in damages to investors. See, e.g., In re Prudential Sec., Inc., [I993 Transfer Binder] Fed. Sec. L. Rep. (CCH) I 85,238 (Oct. 21, 1993). The structure of these Prudential investments was such that problems were unlikely to arise until long after the sales. Since no organized markets existed to assess regularly the value of partnership interests, investors had no easy way to observe a deterioration of value and cut their losses prior to a declaration of insolvency or an IRS challenge to tax deductability. These circumstances alone would create opportunities tempting to a broker who knew of the undisclosed risks. What is striking, however, is how many of these partnerships were sold to new retirees or other persons who had recently come into possession of a large lump sum of money (such as widows or widowers), many of whom were not unsophisticated in general business and financial matters. In this setting, cheating is likely to be uniquely profitable and "safe" for the broker. Because the sums to be invested immediately are so large, the broker will realize sizable short-term returns. Potential problems will arise later, perhaps when the investor is sick or dead, or otherwise unable to complain effectively. Moreover, there are particularly effective influence techniques for selling investments to the otherwise-sophisticated elderly, such as playing heavily on their need for friendship during a time of increasing loneliness and through loss framing on their fears of suffering an erosion of capital and so becoming a burden to others, which simply strengthen the likelihood that many brokers will be unable to resist the temptation. 
concerns. ${ }^{109}$ So long as the broker is even or ahead in his or her sales quota (whether external or self-imposed), opportunistic risk-taking behavior will be restrained. But if the broker perceives a potential for loss or fears a failure to meet expectations, his or her willingness to take risks will increase. Long-term concerns for future business are less salient in an immediate loss frame. As regulators have recently come to acknowledge, the short-term focus of brokerage firm performance measures and compensation systems encourages cheating by both junior salespeople and established producers. ${ }^{110}$ Junior brokers are readily subject to termination for failing to meet quotas. ${ }^{11}$ More established brokers have somewhat greater security but are likely to have much invested in their own sense of status. Either way, the threat of loss is likely to be commonplace and to encourage a mental frame justifying risk taking in the form of opportunistic behavior that threatens the long-term relationship in order to serve more immediate needs.

\section{c. Manipulation and the "Honest" Broker}

While the brokerage business may attract some truly corrupt individuals, the vast majority of brokers appear, and hopefully are, honest, self-respecting white-collar professionals. Most would claim that, whatever the potential strategic payoff, they would not knowingly sell a customer a bad investment; they recommend what they believe to be investments of at least average quality, not abusively priced. However, this does not mean that these brokers would never admit to trying to manipulate their customers. It is the job of all brokers to get the customer to follow their recommendations instead of trading with another firm or not investing at all. Within the context of this commonly understood job, most brokers engage in behavior within the framework of accepted norms of sales gamesmanship.

This is an important subject, for it constitutes the defense in many broker-customer disputes. Broker testimony may be buttressed by seemingly credible references to family, education, or religious or charitable involvement to counter any suggestion of a propensity toward corrupt behavior. The fact-finder may thus be inclined to rule out as a motivation the sort of deliberate strategic behavior described in the pre-

109. Indeed, we can say in general that the choice faced by a broker to risk cheating a customer is subject to nearly all the same motivational distortions that institutional investment agents face when pressured to make a risky investment. See supra notes $45-58$ and accompanying text.

I10. See supra note 70.

111. Anecdotal reports suggest that entry-level brokers are subject to rather extreme "tournaments"-systems that automatically terminate those brokers who fall into the bottom rung of performers in the office or firm. See SALER, supra note 5, at 25 (offering examples of firms firing salespeople not meeting commission quotas). 
ceding Section. ${ }^{112}$ Putting aside the possibility that the broker has deliberately donned the trappings of respectability simply in order to disarm suspicions, ${ }^{113}$ does this lead naturally to the conclusion that the customer has not been taken advantage of?

Not if the broker either underestimated the risk or overestimated the expected return of the security, so that bad advice was given in good faith. Typically, brokers do not do their own specific investment analysis, but rather depend on research provided by other departments of the firm. An individual broker may not fully understand the risk associated with the securities he or she pushes, even though others within the firm do. There is a palpable danger (or value, depending on one's perspective) in utilizing as a salesperson someone who does not fully appreciate the risks of an investment product.

Salespeople are not necessarily likely to be particularly good at assessing product quality, yet they are motivated to assess product risk in a biased fashion. Selling inferior or unsuitable investments is inconsistent with the self-image of brokers who regard themselves as decent, responsible professionals. At the same time, brokers need to maintain a high volume of sales. Brokers who have made a commitment to their careers are motivated to view what they sell as being of acceptable quality and will approach their task through bolstering and rationalization rather than detached analysis in order to satisfy that motivation. The predictable successes will be einphasized and the broker's role in them inflated, while the losers are explained away. Failure to do this produces too much anxiety, and interferes with the self-assurance that is crucial to the persuasiveness of the good salesperson. ${ }^{114}$

112. This inclination is a dangerous, though not entirely irrational, one for a variety of reasons. One robust finding in social cognition experiments is the "fundamental attribution bias": the tendency to explain behavior in terms of underlying disposition rather than (as is more often accurate) situational influences. In other words, people may tend to underestimate the possibility that an apparently "good" person would do a bad thing. FISKE \& TAYLOR, supra note 10, at 67-72.

113. Anecdotally, religious and charitable involvement is not uncommon among con artists; whether this is a cynical part of the con game designed solely to deceive the target or reflects some decper schizophrenia or denial on the con artist's part is an imponderable. The celebrated OPM securities scandal, for instance, was facilitated by the religious and charitable activities of one of its principals. Robert P. Gandossy, Bad Business: THE OPM SCANDAl aNd THE SEduction of THE ESTABLISHMENT 11-12, 20 (1985). More recently, the infamous New Era fraud was played out among a "pewload of evangelical churches" involving wealthy, successful businesspeople. See Lewis, supra note 90, at 18.

114. The sociobiologist Robert Trivers has observed that self-deception is often part and parcel of deceiving others, since a deceiver is more effective when he or she becomes unconscious of the deceit and thus shows no outward manifestations of the deceit. Robert Trivers, Social Evolution 415-16(1985). There is ample evidence that projection of confidence is a key attribute in persuasion. See, e.g., Margaret T. Lee \& Richard Ofshe, The Impact of Behavioral Style and Status Characteristics on Social Influence: A Test of Two Competing Theories, 44 Soc. Psychol. Q. $73,79-81$ (1981) (analyzing group infiuence experiment in which demeanor variations significantly affected observer influence); Bernard E. Whitley, Jr. \& Martin S. Greenberg, The Role of Eyewitness 
Employers know this. A brokerage firm will probably spend a good bit of time inculcating in its salespeople the belief that they are selling good investment merchandise. If the firm succeeds, brokers can rationalize fairly aggressive and manipulative selling tactics. Brokers come to believe that such tactics are all "part of the game," understood and tacitly accepted by market participants so long as the quality of the underlying product is acceptable. Indeed, employers may be able to convince their salespeople that manipulative tactics are in customers' best interests, since customers lack the time and expertise to appreciate product quality on their own, and need to be led to the right conclusion. ${ }^{115}$ If brokers believe the pitch, they experience the happy confluence of higher sales volume and lower moral anxiety. ${ }^{116}$

To suggest that brokers are motivated, and perhaps trained, to deflect risk-positive information poses the question of why the brokerage firm itself would tolerate or even promote its brokers' mischaracterization of risk. ${ }^{117}$ After all, potential customer dissatisfaction and legal exposure are bad for business. No firm would knowingly put its reputation at risk, the industry might argue, by directing its brokers to pitch securities that are likely to cause widespread customer dissatisfaction.

However, this argument is not entirely compelling. Once again, there are issues of both strategic opportunism and psychological bias to consider. Like individual brokers, firms may rationally conclude that the expected returns from a cheating strategy in a given case may exceed the reputational or future business penalty they are likely to

Confidence in Juror Perceptions of Credibility, 16 J. AppLIEd Soc. Psychol. 387, 403-05 (1986) (describing mock juror experiments in which witness confidence increases juror perceptions of credibility). Research also shows that successful salespeople exhibit a high degree of optimism, essentially the subconscious tendency to distort reality in a positive direction. See SeligmaN, supra note 37 , at $98-101$.

115. For a study noting the potential to rationalize aggressive sales techniques in the life insurance industry, see Guy OAKes, The Soul of the Salesman: The Moral Ethos of PERSONAL SALES 49-57 (1990). Training of salespeople justifies sales techniques as an "indispensible contribution" to customer attainment of financial security. Id. at 91 . Validation of gamesmanship and aggressiveness is also useful in other sales-force motivation techniques. Contests and revival-like success celebrations create a strong desire to sell, and the training offers means of rationalizing aggressiveness in pursuing one's quotas. For a discussion of how these techniques are used by the Xerox Corporation, see DAvid DORSEY, THE ForCE (1994).

116. Moral anxiety about the congruence between personal and employer values can indeed interfere with productivity. See, e.g., Barry Z. Posner \& Warren H. Schmidt, Values Congruence and Differences Between the Interplay of Personal and Organizational Value Systems, 12 J. Bus. ETHIcs 341 (1993). Thus, employers have an interest in alleviating or containing this anxiety.

117. As previously noted, loss framing increases the willingness to take risk, and it is likely that denial and rationalization increase accordingly. Thus, the broker who feels pressure to increase sales to avoid some loss or sense of loss and so begins to behave more opportunistically may not be aware of the inoral, ethical, or legal consequences of what he or she is doing. See supra notes 54-57 and accompanying text. 
suffer. To be sure, a firm cannot expect to stay in business long if cheating is systematic and widespread. However, a brokerage firm whose advisory business is perceived as mostly legitimate might find it rational to cheat customers occasionally if the expected payoff is particularly significant. As noted above, customers are less likely to blame the broker or firm with respect to a particular trade if their accounts are generating a sizable amount of random noise through a mixture of good and bad performance. Cheating such customers would lead to relatively little reputational penalty. So long as the firm does not do it too often, allowing the occasional dumping of inferior securities into its customer portfolios may be an optimal strategy.

Conscious corruption at the firm level is probably no more likely than it is among individual brokers, however. Even if the act of dumping was itself unlikely to be detected, any accidental discovery of the existence of such a deliberate strategy could be devastating. The risk is not worth taking.

The more plausible story mirrors the cognitive strategies of individual brokers. In assessing a security to which they have no prior commitment, firm managers probably do a reasonably unbiased job of risk analysis. They will not add to their inventory of investment recommendations those securities which are likely to underperform or whose prices are not fully discounted to reflect known risks. But once the firm has made a commitment to a particular issuer or security, risk-positive information that arises subsequently is unlikely to be evaluated with the same objectivity. The firm itself (meaning the key decision makers acting as a group) is likely to rationalize its prior decisions, and resist admitting an error. ${ }^{18}$ We should not ignore the possibility that firms (through their agents) are subject to the same biases as investors generally, such as overoptimism and underestimation of low level risk. In communicating information to its salespeople, the firm may mute any concern about emerging risk factors. Since the individual brokers are otherwise primed toward optimism about the security, what they hear in even these muted risk messages may easily be further discounted.

Firm monitoring activities will likely not counter such overoptimism. For the same reasons discussed earlier with respect to investment agent risk taking, it is doubtful, except in the aftermath of a crisis, that most firms will choose to intrude too much on the entrepreneurial

118. For some studies extending individual cognitive biases to explain organizational behavior, see Michael A. Diamond, The Unconscious Life of Organizations: Interpreting Organizational Identity (1993); John C. Coffee, Jr., "No Soul to Damn: No Body to Kick": An Unscandalized Inquiry into the Problem of Corporate Punishment, 79 МrCH. L. REv. 386 (1981); Harry-Levinson, Why the Behemoths Fell: Psychological Roots of Corporate Failure, 49 AM. PSYCHOL. 428 (1994). 
autonomy of highly productive employees in order to check this bias. This is especially true where the product being evaluated is exotic enough that expert monitors will be hard to come by. A firm with a large number of products is not necessarily unwise just because its control system tolerates possible excess or misunderstood risk. From an ex ante perspective, the considerable returns flowing from entrepreneurial product expansion will justify even the small likelihood of serious misjudgments occurring with respect to more than a handful of product areas simultaneously. While some firms may suffer dramatically from such a strategy, it may on average be a profitable one to pursue. And once the firm is in possession of inferior products, denial and rationalization will blunt any awareness among its personnel; the salespeople may be sheltered from it completely.

\section{The Role of Competition}

At this point, one lingering question deserves more focused consideration than I have given it. Shouldn't the highly competitive market among brokerage firms constrain opportunistic behavior by both individual brokers and entire firms by creating an environment in which competitors will seek to capitalize on any hint of customer dissatisfaction? To some extent, the answer lies in the analysis of a firm's reputational incentives in deciding whether to risk eventual customer dissatisfaction with what they pitch. As we have seen, in many circumstances there is a relatively low likelihood of conscious customer dissatisfaction from exploitation. The more interesting question regarding the role of competition is why competitors do not act more aggressively to persuade potential customers that they have been exploited by their current broker.

The explanation is largely practical. A competing broker lacks the information necessary to demonstrate exploitation absent a desire by customers to entrust that information to a new broker-something they are unlikely to do absent some dissatisfaction in the first place. ${ }^{119}$ Individual account information is generally kept quite private, for a variety of personal and financial reasons. Moreover, were a broker to succeed in getting access to such data and demonstrating at least the possibility of abuse through bad advice, a new credibility problem would arise. A customer that acknowledges past betrayal will be particularly fearful of trusting anyone else.

119. The ability of market competition to promote disclosure of information to, even unsophisticated consumers is well documented. See, e.g., Alan Schwartz \& Louis L. Wilde, Intervening in Markets on the Basis of Imperfect Information: A Legal and Economic Analysis, 12T U. PA. L REv. 630, 635-39 (1979). 
How could the new broker signal greater trustworthiness? At a minimum, the new brokerage firm would have to demonstrate credibly that its recommendations over a broad range of customers outperform the previous firm and other potential competitors. This claim may be difficult to substantiate if it is true, as many researchers suggest, that few brokerage firms do, on average, consistently provide above-normal returns to their retail customers net of expenses. ${ }^{120}$

\section{A Plausible Generic Story}

The foregoing discussion does not by itself generate any legal insights. That is the subject for Part II. At this point, in fact, I have complicated rather than simplified the overall perspective on brokercustomer interactions. We have seen that both of the stereotypical claims raised in the typical broker-customer disputes-that customers are more willing to take risks in the pursuit of abnormal returns than they care to admit, and that brokers have both the motive and opportunity to manipulate customers into ill-considered decisionscontain sizable grains of truth. A sophisticated customer's ill-fated investment decision usually results from the coincidence of dispositional and situational influences that make the customer particularly inclined to buy, and the broker particularly motivated to sell. Resolution of the dispute must not turn simply on who is at fault, but rather on how responsibility is to be properly divided in the first place.

From what we have learned, we can construct a plausible generic story of what might have happened in celebrated derivatives cases like Gibson Greeting Cards, Procter \& Gamble, or Orange County. ${ }^{121}$ The financial officers who made the purchase decisions would have felt significant externally generated pressure to increase income, and feared an erosion of status within the organization if these expectations could not be delivered. They were aware that sophisticated peer firms were engaging in derivatives activity, with apparent profit. In other words, they were in a loss frame. Like most successful professionals, they had a rather high regard for their abilities, and were unconsciously protective of both self- and external-image.

When approached by the derivatives salespeople, these financial officers were already primed to buy, although they may have consciously articulated the need to be skeptical and careful. The salespeople emphasized their credentials and reputation, and offered examples of other firms quickly taking the opportunity to profit from customized

120. See supra note 73 .

121. See supra note 1; see also G. Bruce Knecht, Derivatives Dregs: Houston Firms Sold Risky "Toxic Waste" for Wall Street Giants, WALL ST. J., Dec. 20, 1994, at A1 (reporting risky, exotic derivatives known on Wall Street as "toxic waste"). 
swaps and other products. They put illustrative projected returns on the table. Encouraged to ask questions, the financial officers probably attempted to convey a greater understanding of the product than they really possessed. Over the course of the sales interaction, the officers likely convinced themselves that they understood the risks, while avoiding (without realizing it) lines of questioning and conversation that would undermine the image of confidence. In the end, they committed to a purchase that they could not, without a loss of face, state good reasons for turning down.

The salespeople may have come to this interaction believing in the general soundness of derivatives investments, but largely shifting cognitive responsibility for specific risks to others withm the firm. They tried to perceive the pressures and self-image their customers faced and brought to the negotiation. The broker carefully tailored the sales pitch to their sense of the financial officers' underlying motivations, emphasizing both the financial (and, more subtly, the status) potential of the investment and its suitability to the buyer's unique circumstances. If risks were mentioned, they were treated as routine and self-evident, not calling for detailed attention.

Once the first purchase was made, under this scenario, the financial officers were inclined to bolster their decision. To the extent that the investment was profitable in the short-run, any lingering concerns were diminished by this positive feedback. Self-confidence was boosted. Having committed themselves to the general wisdom of the investment, the fmancial officers were ready to be approached about more, perhaps riskier, opportunities-opportunities they could hardly turn down without at least implicitly admitting that the first decision might have been a mistake. If, instead, the investment produced short-term adversity (unless the loss was an outright disaster), the enhanced loss frame might well have led them to continue in their course of action as a means of regaining the ground between expectation and result. In either case, they were cognitively primed to resist negative information inconsistent with justification of the investment.

In all of this, the officers' supervisors sensed no cause for concern; much less alarm. Trusting the subordinates whom they selected (particularly in light of the officers' optimism), pleased with the hopedfor returns, and blinded by their own sense of control to the possible consequences of their limited understanding of the instruments in question, the supervisors also deflected anxiety. Once committed to the acceptability of the investment, they, too, were inclined to filter out subsequent dissonant information.

Then, interest rates dropped precipitously. In hindsight, the sales people remember noting the risk and the speculative nature of any pro- 
jections or representations and believe that the financial officers assumed that risk with some degree of awareness. The officers recall little or nothing of any emphasis on risks, but do remember a variety of optimistic representations and assurances. The officers' supervisors blame both parties to the transaction, firing the officers and suing the brokerage firm. Now, there is a lawsuit, providing us with an appropriate point to cross the bridge from the descriptive to the normative.

\section{II}

\section{Some Legal Implications of the Behavioral ANalysis}

Part I teaches that we should reject simplistic, overly polarized views in explainiug overly risky investment decisions, and instead favor a more complicated story of joint responsibility. This Part, in turn, will show how the same insight should inform the way in which law and regulation approach the sale of risky securities.

To date, courts have addressed the problem of sales manipulation from two fundamentally inconsistent points of view that mirror the polarized descriptions of investment behavior. Protectionist courts extend constructs created largely for the unsophisticated investor to help the sophisticated as well, imposing broad duties on the broker to act on the customer's behalf. ${ }^{122}$ These courts often characterize the broker as the customer's fiduciary even in the absence of discretionary authority, and impose disclosure duties that reflect, if not explicitly incorporate, the fiduciary ideology. Other courts, however, steadfastly deny the idea that the broker is the customer's keeper. ${ }^{123}$ Rejecting the fiduciary notion and all that follows from it, these courts tolerate, if not encourage, a level of gamesmanship in broker-customer interactions. The essence of the gamesmanship model is the use of minimalist "rnles of the game" to order broker-customer relationships. ${ }^{124}$

As a result of this divergence, the law of broker-dealer responsibility is hopelessly muddied. ${ }^{125}$ Case outcomes are impossible to predict.

122. The two classic cases from which much of the protectionist jurisprudence derives are Charles Hughes \& Co. v. SEC, 139 F.2d 434 (2d Cir.), cert. denied, 321 U.S. 786 (1943), and Hughes v. SEC, 174 F.2d 969 (D.C. Cir. 1949). For a case noting that even sophisticated investors can rely on the fair dealing of their brokers, see Hanly v. SEC, 415 F.2d 589, 596 (2d Cir. 1969).

123. Among the many cases that fall into this mode, one of the most rhetorically striking is Lefkowitz v. Smith Barney, Harris Upham \& Co., 804 F.2d 154, 155 (1st Cir. 1986) (holding no fiduciary duty to exist in a "simple stockbroker-customer relationship" in which the customer allegedly lacked business knowledge and always followed broker's advice).

124. A gamesmanship model is quite prevalent among business people. See, e.g., MiCHAEL Maccoby, The Gamesman (1976); Albert Z. Carr, Is Business Bluffing Ethical?, Harv. Bus. Rev., Jan.-Feb. 1968, at 143. And it still plays a significant role in lawyers' accounts of appropriate behavior. See James J. White, Machiavelli and the Bar: Ethical Limitations on Lying in Negotiation, 1980 AM. B. Found. Res. J. 921.

125. The question of when an investor should or should not be deemed sophisticated represents perhaps the most significant division among the courts. See, e.g., DAv1D A. Lipton, Broker- 
When we consider the tremendous sums at stake in these disputes, judicial adoption of a more standardized analysis seems vital to market participants. The result of unclear legal standards is, among other things, excessive litigation and arbitration.

This Part seeks to build a normative framework that reconciles some of the tension in existing law and incorporates the learning built in Part I. To do this, I will pursue a middle ground that rejects both broad protectionism and undue gamesmanship. The goal will be to derive and refine a risk disclosure obligation-securities law's favorite strategythat is not fiduciary-based and that does not unrealistically presume a broker's full responsibility for customer welfare. The trick, made much more difficult as a result of what we have learned, is in trying to make sure that the disclosure is effective.

\section{A. The Conceptual Debate Over the Treatment of Sophisticated Investors}

In a rational world, sophisticated investors need no protection from overreaching by brokers beyond a simple and restrained antifraud prohibition. Not so in the real world, as we have come to see. Once we accept that otherwise sophisticated investors may engage in sub-optimal decision making with some frequency, there is an intuitive appeal in imposing on brokers an affirmative duty to reduce customer risk taking that reflects such taiuted judgment. As the skilled professionals in the sales interaction, perhaps brokers should learn to avoid biasing customer decisions. In the aftermath of the various derivatives scandals, there is a push for regulatory reform in precisely this direction. ${ }^{126}$

A deliberate expansion of protectionism along these lines is not without its merits. A strict protectionist scheme could reduce the frequeucy of notorious cases of excessively risky investment choices. These choices cause severe financial harm to the investor and-in institutional cases-to those who have some beneficial interest in the portfolio, and distort the efficiency of the processes by which capital is allocated within our economic system. With their superior knowledge

\footnotetext{
Dealer Regulation § 5.01[3][a] (1995); Poser, supra note 70, § 2.2.4. Protectionist courts can readily accomplish their aims by narrowing the category of who is sophisticated, otherwise preserving a harsh analytical structure for those few who do not qualify. E.g., Weiser v. Shwartz, 268 F. Supp. 389 (E.D. La. 1968) (characterizing a business person who was a member of an advisory board of both a bank and an insurance company as unsophisticated). Courts look to such factors as prior investment experience, subscriptions to financial publications, and understanding of investment terms. E.g., Landry v. Hemphill, Noyes \& Co., 473 F.2d 365, $373-74$ n.10 (1st Cir. 1973), cert. denied, 414 U.S. 1002 (1973); see LIPTON, supra, \$ 5.01[3][a]. One of the strong messages of the behavioral analysis is that such categorization can easily be misleading.

126. Many of these initiatives are collected and analyzed in Geoffrey B. Goldman, Note, Crafting a Suitability Requirement for the Sale of Over-the-Counter Derivatives: Should Regulators "Punish the Wall Street Hounds of Greed"?, 95 CoLUM. L. REv. 1112 (1995).
} 
and expertise, and already being subject to detailed regulatory supervision, brokers could well be the "least-cost avoiders" of these harms.

While a full-scale expansion of legal protection is facially appealing, however, there are serious reasons to doubt that it would be either wise or practicable. ${ }^{127}$ These concerns deserve careful attention, and fall into two broad categories.

\section{Arguments About Customers' Due Care}

One premise of many anti-protectionist perspectives is that the usual "sophisticated" investor is-and should be-wary and vigilant in sales interactions. As one court has suggested, "any reasonable investor knows to be somewhat wary of a selling agent's oral representations" and other blandishments. ${ }^{128}$ Those who too readily trust their brokers are gullible in a way that departs from the standard of ordinary care and prudence, and therefore they can only blame themselves for their misfortune. Consequently, absent some evidence of incapacity or duress (at which point they will simply be declared unsophisticated), fairness dictates no more protection for the sophisticated investor than the mimimal "rules of the game" to guide the process of arm's length bargaining.

As noted earlier, the behavioral research amply supports one aspect of this claim. Usually it is the investor's own needs-ego, status, or pure greed-that interfere with what ideally would be a rational assessment of the investment opportunity. An aggressively protectionist legal regime has the effect of imposing responsibility on the broker for highly subjective choices and preferences. On the other hand, behavioral research also demonstrates the pervasiveness of trust in broker-customer relationships. It is this factor that is so readily subject to manipulation and upon which our legal analysis should focus.

Again, investors need and want to trust their brokers, and many brokers are skilled at establishing trust by exploiting those motivations. Once the investor has committed to a relationship with a broker, he or she experiences substantial cognitive resistance to dissonant information that might trouble a more unbiased observer. If the proper legal regime is premised upon eliminating manipulation and deception in the selling process, as are the securities laws generally, blaming the investor for her

127. See Jerry W. Markham, Protecting the Institutional Investor-Jungle Predator or Shorn Lamb?, 12 YALE J. REG. 345 (1995) (doubting the desirability of new protectionism for the sophisticated investor).

128. Brown v. E.F. Hutton Group, 735 F. Supp. 1196, 1202 (S.D.N.Y. 1990), aff'd, 991 F.2d 1020 (2d Cir. 1993); see also Porter v. Shearson Lehman Bros. Inc., 802 F. Supp. 41, 57-58 (S.D. Tex. 1992) (finding unreasonable reliance on statements made outside of prospectus that clearly disclosed risk factors). 
own cognitive failings created by the broker's manipulative selling tactics hardly seems fair.

Many lawyers and judges probably underestimate the commonness and reasonableness of trust in these settings. I have written elsewhere about "the lawyer's bias": the phenomenon, grounded in the "false consensus effect," whereby lawyers and judges assess reasonableness through the rose-colored lens of how they think they would behave under similar circumstances. ${ }^{129}$ Nearly everyone overestimates the prudence of their own predicted behavior under hypothetical circumstances; lawyers bring to this predictive process training and experience that emphasizes skepticism of the motives of others and obsession with formality and the written word. Lawyers and judges, in other words, may well infer that sophisticated investors typically act in a lawyer-like fashion when contemplating an investment, proceeding deliberately, questioning everything. Thus, lawyers feel justified in concluding that trust is foolish. In fact, however, it is quite possible that even lawyers do not act with a great degree of prudence in their own investment activity. ${ }^{130}$ The gamesman model may well take sustenance from a biased misperception about what constitutes ordinary care in investment sales interactions. Perhaps ordinary care is to trust a broker's seemingly reasonable recommendations.

But gamesman opponents of protection, including some judges, raise a second objection: regardless of how investors typically do act as a descriptive matter, efficiency dictates that they should be wary and skeptical. Penalizing undue trust is thus simply a way to create a legal incentive toward cognitive diligence and discourage reliance on motivated heuristics and biases.

If extensive trust is common and predictable, however, it would take an unusually strong and clear legal message to dissuade investors from relying ex ante. If such a message is too strong, along the lines of strict caveat emptor, it risks discouraging otherwise desirable transactions. Yet if it is any less, its impact will be blunted. In general, we can expect that individual investors will usually underestimate the risk that they would be disadvantaged by the law. ${ }^{131}$ The product of a successful sales interaction is the customer's belief that she is acting prudently. The

129. See Langevoort, supra note 31, at 881-83; Donald C. Langevoort, Disclosures that "Bespeak Caution," 49 Bus. LAw 481, $493-94$ (1994) [hereinafter Langevoort, Disclosures].

130. See, e.g., Nicholas Wolfson, Investment Banking, in Abuse ON Wall STREeT: CONFLICTS OF INTEREST IN THE SECURITIES MARKETS, supra note 70, at 365, 378-81 (reporting SEC hearing testimony of one lawyer who would "go ahead and buy" a stock without reading the prospectus if he knew and liked the broker and another who felt prospectuses have "limited usefulness" in deciding whether to buy a new issue); see also supra note 77 and accompanying text.

131. See Eisenberg, supra note 9, at 225-40 (making a similar point with respect to the efficacy of liquidated damages clauses and express conditions in contract law). 
decision to trust is essentially the prediction that the sort of harm that ends up in a legal dispute is unlikely, sufficiently so that it will be ignored completely. ${ }^{132}$ Generally, then, trust trumps law. Moreover, learning from experience is a slow and unsure process. In the meantime, opportunistic brokers will have ample chances for predatory enrichment. Under these circumstances, it is wiser to place responsibility on brokerage firms, which seem less subject to bias, ${ }^{133}$ have in the aggregate a better sense of sales interactions, and more systematically receive legal advice to which they can conform. In sum, unless one objects to the teachings of the behavioral literature in the first place, arguments that go to the customer's due care fail to justify persuasively the gamesman's objections. ${ }^{134}$

\section{Costs and Burdens}

The second anti-protectionist argument concerns the costs and difficulty of regulation. In fact, here the behavioralist perspective turns back and bites the protectionists. If one clear message can be derived from Part $I$, it is that it is difficult to cause investors to act cautiously once they are motivated to buy. To the extent that an investment decision reflects some need or desire beyond the simple expectation of profit, most forms of information and warnings inconsistent with the desired course will be iguored, filtered out, or rationalized away. As a result, any effective form of regulatory intervention must have its impact before motivation takes hold.

This intervention is burdensome for two reasons. The first is expense. The early stages of a sales interaction are personal and informal, hard to monitor or to supervise. Regulation is thus likely to be intrusive, with paperwork and red tape naturally raising the costs of offering legitimate advisory and informational services. Serious costs also attend the process of dispute resolution, since the oral nature of most sales interactions will make it hard to determine with certainty what was discussed during a sales pitch. Customers and brokers will often be able to hide behind undetectable perjury or self-serving biased memories. Furthermore, there is a considerable risk of false claims and erroneous retrospective decision making under a regime that makes the broker the customer's keeper, especially when we keep in mind that the motivations leading to excessive risk taking usually derive from the customer, sometimes without broker manipulation. These problems with dispute

132. See supra note 41 .

133. Precisely how much less biased is questionable, as suggested supra in Section I.B.2.c. Indeed, brokerage firms may underestimate the amount of broker manipulation and opportunism. See supra notes 59-67 and accompanying text.

134. These arguments may well work better in the institutional setting. This question will be considered infra notes 206-211 and accompanying text. 
resolution will create considerable litigation and arbitration, the costs of which will be spread to investors generally, taxing the capital-raising process.

Beyond this, however, there is a second cost: the very chill on the salesperson's arts and techniques. For all our concern about manipulation of customer demand, I suspect that there is an inchoate policy preference for wanting stockbrokers to be able to sell securities somewhat aggressively. Capital formation is at the heart of our economic system and is driven by demand for securities. Without allowing for a certain level of induced demand, we may fear that society's capitalistic dreams will not be realized. ${ }^{335}$

We cannot easily dismiss these two burdens potentially imposed on investment markets by increased protectionist regulation, as perhaps we could for the first set of arguments. Open-ended protectionist regulation for the sophisticated investor will be extreinely expensive and difficult to administer. And while Lynn Stout ${ }^{136}$ and others ${ }^{137}$ have raised interesting questions about whether we might not have too many securities transactions, benefiting Wall Street to a far greater extent than the American economy generally, our national policy has generally been in favor of encouraging a high level of investment activity, which in turn implies a reasonable degree of freedom for the salesperson.

Although I accept the strength of this neoclassical objection, it does not justify a prompt reversion to the laissez faire, as some courts seem to assume. Such an approach simply restores the opportunity for unfair investor predation and harmful economic distortions described in Part $I$. The remainder of this Part, then, aims to articulate and justify a middleground position that balances the various interests. It seeks to focus our analysis of the broker-customer relationship on the often reasonable trust and reliance fostered by brokers.

135. Compromise has never been far from the surface in securities regulation. Its most visible manifestation can be seen in the transformation of the Securities Act of 1933. As originally drafted, the Act was based on a simple model: the selling process in a public offering of securities could not begin until a formal disclosure document was in the hands of the potential investor, against which the truth of the broker's sales pitch could be measured. By the 1950 s however, this gave way-finally blessed by statutory reform-to a scheme whereby oral sales solicitations could freely occur while the prospectus was being finalized. See generally I Louis Loss \& JOEl SELIGMAN, SECuRITIEs' REGULATION 408-21 (3d ed. 1988). The justification for this change had nothing to do with investor protection; rather, it had to do with a combination of a perceived need to be able to assess investor demand prior to final pricing of the deal and a bow to the way offerings had long been sold. In other words, allowing oral solicitations prior to the effective date was to some extent a trumping of investor protection in the name of capital formation.

136. Stout, supra note 13, at 710-12.

137. E.g., Louis Lowenstein, What's Wrong With Wall Street: Short-term Gain AND THE ABSENTEE SHAREHOLDER 80-86 (1988). 


\section{B. Characterizing the Relationship: Are Brokers Fiduciaries?}

\section{The Fiduciary Conundrum}

One of the most common issues arising in broker-customer disputes is whether it is proper to characterize the relationship as fiduciary. ${ }^{138}$ If so, then a host of legal consequences follow, all designed to penalize actions by brokers that seemingly place their interests before those of their customers. ${ }^{139}$ To be sure, as we are often reminded, characterization of a status as fiduciary in nature only "begins [the] analysis": ${ }^{40}$ the precise consequences are determined contextually. At the very least, however, fiduciary status creates a presumption that certain basic, "off-the-rack" rules-drawn largely from the law of agency and trusts-will apply. ${ }^{141}$ The burden is on the fiduciary to show that he or she handled conflicting interests "with [the] utmost good faith"142-a standard of considerable rhetorical power. Fiduciary language thus stacks the deck. In reading the case law, one strongly senses that once a brokerage relationship is characterized as fiduciary, the customer is poised to win. ${ }^{143}$

138. See PoSER, supra note 70, $\S 2.1-2.2$; Carol R. Goforth, Stockbrokers' Duties to Their Customers, 33 Sr. Lours U. L.J. 407 (1989).

139. One of the most significant consequences is remedial: a breach of fiduciary duty triggers an effort to avoid the unjust enrichment of the wrongdoer as well as to make the victim whole. See E. Allan Farnsworth, Your Loss or My Gain: The Dilemma of the Disgorgement Principle in Breach of Contract, 94 YALE LJ. 1339, 1354-60 (1985) (declaring the "main drawback" of remedies for fiduciary breach to be insufficient regard for causation). For a collection of materials and commentary relating to the nature and consequences of fiduciary status, see DEBORAH A. DEMoTT, Fiduciary Obligation, Agency and Partnership: Duties in Ongoing Business RELATIONSHIPS (1991).

140. SEC v. Chenery Corp., 318 U.S. 80, 86 (1943).

141. See, e.g., Jordan v. Duff \& Phelps Inc., 815 F.2d 429, 434-37 (7th Cir. 1987), cert. denied, 485 U.S. 901 (1988) (describing fiduciary duty as a "standby" guess about parties' intentions in absence of explicit contractual arrangements). This is not to say, however, that resort to contract principles is necessarily helpful. See Deborah A. DeMott, Beyond Metaphor: An Analysis of Fiduciary Obligation, 1988 DUKE L.J. 879. DeMott's central claim is that courts often use the rhetoric of fiduciary ideology as a substitute for more thorough analysis. Id. at 923-24.

142. See Twomey v. Mitchum, Jones \& Templeton, Inc., 69 Cal. Rptr. 222, 236 (Ct. App. 1968) ("The relationship between broker and principal is fiduciary in nature and imposes on the broker the duty of acting in the highest good faith toward the principal."). On the consequences of the fiduciary determination, see Robert Flannigan, The Fiduciary Obligation, 9 OXFORD J. LEGAL STUD. 285 (1989); Tamar Frankel, Fiduciary Law, 71 CALIF. L. Rev. 795 (1983).

143. Indeed, in certain statutory contexts (the Employee Retirement Income Security Act (ERISA), for example), a fiduciary determination triggers severe and rigid consequences. Under ERISA, a fiduciary of a pension plan is barred from engaging in a variety of otherwise profitable forms of activity. 29 U.S.C. $\$ 1104$ (1994). "Fiduciary" in this context is defined somewhat differently than under the general common law, to include the rendering of investment advice for compensation. 29 U.S.C. $\S 1002(21)(A)$ (1994); Poser, supra note 70, § 2.4.2. Commodities regulation also provides severe consequences: a commodities broker (futures commission merchant) may be held to a higher set of customer disclosure responsibilities if the relationship is characterized as fiduciary. See Tmothy J. SNider, II, Regulation of the Commodimies Futures and Options Markets, § 12.34 (2d ed. 1995). 
There is no question that some customer-broker relationships are fiduciary. In a discretionary account, the customer gives the broker authority to buy or sell without the need for approval. That understanding properly leads to the imposition of trustee-like responsibilities. There is no reasonable way of interpreting the contract between the two parties except as containing an implied term that the broker will act solely in the customer's best interests.

Once we move beyond the discretionary account, however, the issue is more problematic, and the case law decided under both common law and federal securities regulation becomes almost completely unpredictable. ${ }^{144}$ A common test asks whether, notwithstanding the customer's formal involvement in approving each transaction, the broker nonetheless "controls" the account. ${ }^{145}$ Most courts recognize that a broker's relationship with a truly unsophisticated customer can lead to de facto control. A customer incapable of understanding the nature and consequences of the broker's recommendations has little choice but to follow those recommendations, to act solely upon whim, or to find a new broker.

The difficult distinctions occur, however, with a sophisticated customer who has the ability and experience to understand the substance of the investment decision, yet still places considerable trust in the broker and follows broker recommendations most or all of the time. Some courts say that apart from an actual or de facto discretionary account, the broker-customer relationship is never fiduciary in nature. ${ }^{146}$ Others turn that presumption on its head, finding the relationship fiduciary absent special circumstances. ${ }^{147}$ Many create no presumption, requiring instead an ad hoc multi-factor inquiry into whether a sufficient relationship of trust and confidence was created, with the level of customer sophistication typically a central issue. ${ }^{148}$

144. See PoSER, supra note 70, $\$ 2.1 .2$; Goforth, supra note 138 , at $422-31$. A recent judicial effort to survey the conflicting case law appears in Marchese v. Nelson, 809 F. Supp. 880, 892-95 (D. Utah 1993).

145. E.g., Davis v. Merrill Lynch, Pierce, Fenner \& Smith, Inc., 906 F.2d 1206, 1214-16 (8th Cir. 1990) (federal securities law); Leboce, S.A. v. Merrill Lynch, Pierce, Fenner \& Smith, Inc., 709 F.2d 605, 607 (9th Cir. 1983) (California law).

146. E.g., Lefkowitz v. Smith Barney, Harris Upham \& Co., 804 F.2d 154 (Ist Cir. 1986); Shearson Hayden Stone, Inc. v. Leach, 583 F.2d 367, 371-72 (7th Cir. 1978); Merrill Lynch, Pierce, Fenner \& Smith, Inc. v. Boeck, 377 N.W.2d 605, 609-10 (Wis. 1985).

147. E.g., Romano v. Merrill Lynch, Pierce, Fenner \& Smith, Inc., 834 F.2d 523, 530 (5th Cir. 1987); Duffy v. Cavalier, 264 Cal. Rptr. 740, 748-52 (Ct. App. 1989) (emphasizing irrelevance of sophistication); Hayden Stone Inc. v. Brown, 218 So. 2d 230, 235 (Fla. Dist. Ct. App.), cert. denied, 225 So. 2d 539 (Fla. 1969); Roth v. Roth, 571 S.W.2d 668 (Mo. Ct. App. 1978).

148. E.g., Paine Webber, Jackson \& Curtis, Inc. v. Adams, 718 P.2d 508, 517-18 (Colo. 1986) (en banc). For a case characterizing an institutional investor-broker relationship as fiduciarylargely emphasizing the superior knowledge factor-see MidAmerica Fed. S\&L v. Shearson/American Express, Inc., 886 F.2d 1249, 1258-59 (10th Cir. 1989). 
Two difficulties make resolving this doctrinal problem especially vexing. ${ }^{149}$ One is simply an intellectual trap. To the extent that the customer asks the broker to execute a transaction, their relationship naturally becomes one of principal-agent for that particular task. Since agents are generally deemed fiduciaries, it is easy to expand that characterization mindlessly to the whole of the relationship. The other difficulty is the elastic use of the fiduciary construct in American law, which gives a judge ample room to implement either a protectionist or a gamesman approach to the subject. ${ }^{150}$ Since brokers and customers rarely discuss the fiduciary issue explicitly, courts generalize by speaking of the "reasonable expectations" in customer-broker relationships in deciding whether to create a presumption, and if so what that presumption should be.

It is not hard to discern the underlying issue in these kinds of cases. Should the fact that the customer has placed trust in the broker's advice be enough to create fiduciary (or quasi-fiduciary) status? One can easily read the protectionist cases to suggest so. ${ }^{151}$ Mere trust is not enough, of course; it must be invited and reasonably reposed. But as we have seen, the broker's central task is to generate trust as quickly as possible, perhaps disingenuously through a series of often-practiced influence techniques. Thus, there exists little doubt that in nearly all brokercustomer relationships, trust is indeed invited.

149. Both of these difficulties are apparent in the positions taken by various SEC commissioners. See In re E.F. Hutton \& Co., Exchange Act Release No. 25,887, [1988-89 Transfer Binder] Fed. Sec. L. Rep. (CCH) I 84,303 (July 6, 1988) (seeking to apply agency law to the brokercustomer relationship); see also Randall W. Quinn, Deja Vu All Over Again: The SEC's Return to Agency Theory in Regulating Broker-Dealers, 1990 CoLum. Bus. L. Rev. 61 (analyzing the controversy that the E.F. Hutton case created).

150. The proper mode of analysis im imposing a fiduciary duty in a contract-based setting should be: (1) whether the alleged fiduciary made a credible express or implied representation that he or she would act on the other party's behalf, and (2) whether the other party accepted that trust. To be sure, many courts expand the definition of fiduciary obligation to include situations in which the beneficiary may or may not trust the agent/fiduciary. However, the relationship is such as to make the imposition of fiduciary responsibility appropriate because of such matters as the ability to dominate or the possession of confidential information. See Flannigan, supra note 142, at 286-87.

151. Indeed, the law often equates "fiduciary" relationship with relationship of "trust and confidence." See, e.g., Twomey v. Mitchum Jones \& Templeton, Inc., 69 Cal. Rptr. 222, 235 (Ct. App. 1968) ("Confidential and fiduciary relations are, in law, synonymous and may be said to exist whenever trust and confidence is [sic] reposed by one person in the integrity and fidelity of another.") (citing Estate of Cover, 204 P. 583, 588 (Cal. 1922)). In Paine Webber, 718 P.2d at 518, the court adopted the "control" test for determining whether a broker-customer relationship is fiduciary, but made clear that "trust and confidence are so closely related to control that when a customer reposes such a degree of trust and confidence in a broker as to suggest a fiduciary relationship, the broker will almost inevitably have functional control over the customer's account." It is well established, of course, that trust and confidence by itself is not enough-a fiduciary relationship is not created where the alleged fiduciary did nothing to invite or justify the reliance. E.g.o Stevens v. Abbott, Proctor \& Paine, 288 F. Supp. 836, 846-47 (E.D. Va. 1968). 
The harder question, which no doubt most divides the judges, is the extent to which it is reasonable for the sophisticated investor to repose this trust in a broker. Gamesman judges suggest minimal protection for the sophisticated customer's right to rely. Yet our behavioral analysis suggests that this simply is not the correct answer. Even sophisticated customers lack the time and the capacity to become informed on their own about comparative investment opportunities. By practical necessity, they must rely on others; by motivation, they are often strongly inclined to do so.

The question of reasonableness depends on whether the broker's reputation is such that reliance appears to carry a diminished risk of opportunistic behavior. The right-to-rely test should be satisfied upon a finding that the broker individually, or the broker's firm, has successfully cultivated a reputation for credibility. And once again, because the central function of broker and firm marketing activities is to cultivate such a reputation, the presumption should favor a right to rely on any registered broker-dealer's representations and recommendations. Only the presence of contrary facts-red flags about a broker or firm visible even to a committed customer-should detract from that conclusion. If "E.F. Hutton talks," with the intent to influence customer decision making, it should be reasonable for the customer to listen.

Were the only choice between fiduciary and arm's length regimes, it would follow that in most cases the broker-customer relationship should be deemed fiduciary. But we should recognize the conceptual risk of such a characterization. Although many of the consequences of imposing fiduciary obligations on brokers are salutary, there is an immense awkwardness as well. ${ }^{152}$ Finding a fiduciary relationship simply because trust was invited and reposed has the potential to fiduciarize much of the repeated selling activity in the United States, destabilizing the more moderate legal doctrines that otherwise exist in this area. ${ }^{153}$

152. See Gregory A. Hicks, Defining the Scope of Broker and Dealer Duties-Some Problems in Adjudicating the Responsibilities of Securities and Commodities Professionals, 39 DePaul L. Rev. 709, 711-12 (1990) (noting the concern about undue expansiveness, but calling for better articulation of the rationale underlying finding such responsibility in individual cases). Practically, it may be irrelevant whether a fiduciary relationship is present or not. Even if a court decides that a relationship is fiduciary in character, it may still determine that the implicit contract between the parties allowed for a good deal of self-serving behavior. See First Union Discount Brokcrs Servs. Inc. v. Milos, 997 F.2d 835, 846-47 (11th Cir. 1993); Poser, supra note 70, § 2.1.2. Nonetheless, it is not clear that most courts treat a finding of fiduciary status as a mere preliminary to the hard work of assigning content to the relationship. See generally DeMott, supra note 141.

153. See Committee on Children's Television Inc. v. General Foods Corp., 673 P.2d 660, 675-76 (Cal. 1983) (holding that statutory and common law doctrines were sufficient to protect consumers without imposing fiduciary duty on cereal sellers). This issue of trust arises in a number of settings (e.g., banker-customer relations, franchises), well surveyed in DEMOTT, supra note 139, at 347-490. While one risk of attempting to treat the broker-customer relation as fiduciary may be overbreadth in the form of excess, another may be underprotection. Many courts simply refuse to see this 
Successful salespeople inevitably generate trust, seeking repeat business that becomes a pattern or relationship. ${ }^{154}$ Someone buying a complicated office product or computer system relies on the representations and recommendations of the salesperson for exactly the same reasons that the buyer of securities relies on a broker. As with securities, the key to trust in all sales relationships is a reputation for credibility, which can be artificially constructed.

Yet we do not typically find fiduciary status in these other kinds of sales cases. One reason involves the nature of the representation a salesperson makes in trying to establish credibility. A salesperson does not undertake to act on the customer's behalf in the interaction. Rather, the trust message is that "our self-interest is in treating you fairly, and thus your reliance is justified." Trust is mutually beneficial. ${ }^{\text {Iss }}$ Imposing a fiduciary relationship distorts the process of arm's length interaction between sophisticated parties, for in these transactions the very fact of a purchase and sale implies a mutually acceptable selling process. The law of fiduciary obligation is not well designed for sophisticated commercial settings; too much of its imagery and too many of its off-therack rules clash with the culturally accepted dynamics of sales interactions.

For this reason, it is probably more appropriate if courts do not treat brokers as fiduciaries in the absence of a discretionary account or compelling evidence that the broker really does control a given customer's decisions ${ }^{156}$ - so long as we can find some other mechanism for controlling opportunism. Brokers' professional role is sales- and profit-oriented; their training and culture do not suggest an obligation to act in the customers' best interests for any reason other than external

relationship as fiduciary. These courts may well be led to conclude that customers should be left to the "morals of the marketplace" once they have determined that fiduciary characterization is inappropriate. Seeking a more moderate characterization may then lead to a greater number of courts willing to give some protection in the first place.

154. See Oakes, supra note 75, at 674.

155. See Gillette, supra note 41 , at 540 .

156. For a chuming case in which control was justified on a questionable basis, see Arcenaux v. Merrill Lynch, Pierce, Fenner \& Smith, Inc., 767 F.2d 1498 (11th Cir. 1985) (affirming a finding of control because the broker may have "intimidated" his otherwise sophisticated customer). Under ERISA, with its more rigid consequences to finding fiduciary status, there is a distinct tension in the law relating to whether sellers of securities and other financial products should fall within the statutory definition. Compare Consolidated Beef Indus. Inc. v. New York Life Ins. Co., 949 F.2d 960 (8th Cir. 199I), cert. denied, 503 U.S. 985 (1992) and Farm King Supply, Inc. v. Edward D. Jones \& Co., 884 F.2d 288 (7th Cir. 1989) (holding underwriters' advice part of sales pitch; hence, no fiduciary status) with Thomas Head \& Greisen Employees Trust v. Buster, 24 F.3d 1114 (9th Cir. 1994) (holding multiple investment sales by firm and provision of generalized advice created fiduciary status), cert. denied, 115 S. Ct. 935 (1995). 
legal standards and good business practice. ${ }^{157}$ Nor is there any reason to think that supposedly experienced customers expect selfless (as opposed to honest) behavior from their brokers. The customer should be expected to understand that the obvious goal of any offered advice, no matter how credible or trustworthy, is to generate business. As a result, it makes more sense to look elsewhere for legal standards to promote the duty to deal honestly that follows naturally from the right to rely.

\section{The Shingle Theory}

A well-known alternative to the fiduciary construct invokes what is known as the "shingle theory."158 This theory states that by the very act of holding themselves out to the investing public as stockbrokers, brokers make an implied representation that they will deal fairly with their customers. The most interesting aspect of the shingle theory is its ability to turn a breach of the duty of fair dealing into a fraud remediable under the Securities Exchange Act of 1934. Any concealed form of unfair dealing is inconsistent with the shingle theory's implied representation, and thus inherently deceptive.

Putting aside the question of whether the "fraud" aspect of the shingle theory is theoretically sound, ${ }^{159}$ the underlying implied representation makes a good deal of sense as a legal presumption. As noted, the securities industry succeeds by generating trust, conveying to the customer a sense of comfort with the credibility of the broker's information and recommendations notwithstanding the arm's length character of the interaction. Although one can imagine situations (such as cold-calling specialists in the classic boiler room) where very few plausible representations of credibility are in fact communicated to the solicited customer, these are the exceptions. Underlying the shingle theory is nothing more than a reasonable right to rely once the interaction between broker and customer evolves into an exchange-based relationship.

Nor should such a presumption be considered odd. Contract law generally imposes an implied obligation of good faith and fair dealing as a mechanism for sanctioning abusively opportunistic behavior by one

157. See Ezra G. Levin \& William M. Evan, Professionalism and the Stockbroker, 21 Bus. LAw. 337, 350-51 (1966) (explaining that brokers do not act as "professionals" with an independent obligation of ethical dealing).

158. E.g., Charles Hughes \& Co. v. SEC, 139 F.2d 434 (2d Cir. 1943), cert. denied, 321 U.S. 786 (1944); VIII Loss \& SELIGMAN, supra note 135, at 3772-98.

159. For an analysis and justification of this aspect of the shingle theory, see Donald $\mathbf{C}$. Langevoort, Fraud and Deception By Securities Professionals, 61 Tex. L. REv. 1247, 1282-83 (1983); see also VIII Loss \& SeligmaN, supra note 135, at 3779; Roberta S. Karmel, Is the Shingle Theory Dead?, 52 WaSh. \& LeE L. Rev. 1251 (1995). 
party. ${ }^{160}$ This also makes sense in light of the arm's length trust on which relational investment contracting is typically based. The shingle theory simply imports this concept into the specific doctrinal construction of brokers' responsibilities, and treats the broker-customer relationship as a form of contractual understanding.

As with the duty of good faith in contract law, we should not put more weight on the shingle theory's implied representation aspect than it can reasonably bear. The shingle theory does not imply a representation of fiduciary responsibility. Requirements of good faith and fair dealing limit but do not destroy the broker's ability to act in a selfinterested fashion vis-à-vis the customer. The line between opportunism and legitimate profit seeking is often blurry and unpredictable. Because most of the interesting shingle theory problems deal with advice and recommendations, I will save an elaboration on the duty of fair dealing for later on, where it blends with modern developments in the law of fraud.

\section{The Duty to Read}

In recent years, courts have become increasingly stringent in enforcing investors' "duty to read" in securities transactions. In cases addressing this issue, investors have alleged that their brokers orally misrepresented the risk characteristics of a security during the sales pitch. At some point, however, the broker delivered to the investor a written disclosure memorandum containing sufficient disclaimers or cautionary language, which the investor presumably failed to read. Almost always, it seems, the failure to read the disclosure document precludes the fraud claim. ${ }^{161}$

The best known example of this scenario is Brown v. E.F. Hutton Group Inc., ${ }^{162}$ in which the Second Circuit applied the duty to read to

160. E.g., Restatement (SECOND) of CONTRACTs $\S 205$ (1981); Robert S. Summers, The General Duty of Good Faith-Its Recognition and Conceptualization, 67 CoRNell L. REv. 810 (1982).

161. In administrative proceedings, brokers have fared far less well with this "duty to read" defense. See, e.g., In re Ferragamo, [1986-87 Transfer Binder] Comm. Fut. L. Rep. (CCH) I 23,795 (CFTC 1987); In re J.P. Howell \& Co., 43 S.E.C. 325, 329 (1967), aff'd, 395 F.2d 349 (2d Cir. 1968). The SEC's monumental action against Prudential Securities, see supra note 108, assumes without substantial discussion that written risk disclosure is not curative for misrepresentation. For a discussion of the tension between the judicial and administrative approaches, see Joseph A. Franco \& Laura L. Gansler, Written Disclosures that Bespeak Caution and Oral Misstatements by Brokers, 10 INSIGHTS 19, 21 (1996).

162. 991 F.2d 1020 (2d Cir. 1993); see also Dodds v. Cigna Sec. Inc., 12 F.3d 346 (2d Cir. 1993) (holding prospectus disclosure of risk of investments put investor on notice of claims, barring recovery under statute of limitations), cert. denied, $114 \mathrm{~S}$. C. 1401 (1994). For earlier cases in this genre, see, e.g., Kennedy v. Josephthal \& Co., 814 F.2d 798 (1st Cir. 1989); Zobrist v. Coal-X Inc., 708 F.2d 1511 (10th Cir. 1983). The SEC expressed specific disagreement with Brown in In re Foster, Exchange Act Release No. 7,077, 57 S.E.C. Docket 455, 456 n.2 (July 20, 1994). One of this rule's 
the claims filed by investors in a risky limited partnership offering. The investors styled themselves as "unsophisticated," although they were apparently wealthy enough to participate in the unregistered limited offering under the federal securities laws. ${ }^{163}$ The sales pitch was oral, and the investors later alleged that both risk and return were mischaracterized. The brokers also gave the investors a brochure, which the court conceded was a selling document, emphasizing the positive and lacking effective risk disclosure. Effective risk disclosure was provided to the investors in the form of a prospectus, although the court never says when. The sales brochure referred the reader to the prospectus for significant additional information. The court held that even assuming that the investors were unsophisticated, they had a duty to read the prospectus. Their failure to do so was "reckless" as a matter of law, and hence their fraud claim under Rule $10 \mathrm{~b}-5$ was barred. ${ }^{164}$

Ready characterization of a failure to read a dense and detailed prospectus as "reckless" is troublesome on a number of levels. Most obviously, there is an empirical problem. It is awkward to use the term reckless to describe behavior that is quite normal and expected. Yet anecdotal evidence, supported by many people's assumptions about investment practices, indicates that most nonprofessional investors do not read the prospectuses and other legal disclosure documents they are given. ${ }^{165}$ If this perception is accurate, the court's assumption that reasonable investors know better than to rely on brokers' oral representations and selling brochures is a flight from reality.

Our behavioral analysis demonstrates quite clearly why investors rarely read (or read carefully). Investors rely on brokers' recommendations as a way to save time and expense, and to avoid the overwhelm-

most powerful uses is in combination with the so-called "bespeaks caution" doctrine. This doctrine holds that even if projections tum out to be false they are not actionable so long as the forecasts were accompanied by sufficient warnings about the inherent speculativeness of the predictive process. See, e.g., Porter v. Shearson Lehman Bros. Inc., 802 F. Supp. 41 (S.D. Tex. 1992). A court might thus conclude that oral projections cannot be the basis for fraud if the written disclosure document "bespoke caution." Such a conclusion would be troublesome, for projections are often given heavy weight by investors. Note, however, that many of the most recent formulations of the bespeaks caution doctrine emphasize that the warnings have to be in close proximity to the projection. See In re Donald Trump Casino Sec. Litig., 7 F.3d 357 (3d Cir. 1993); Langevoort, Disclosures, supra note 129 , at $488-89$.

163. Brown, 991 F.2d at 1032.

164. Under Rule 10b-5, simple negligence will not bar a plaintiff's claim; hence, for the suit to be precluded, the court must find some higher level of conscious or reckless disregard for the truth. See James D. Cox -et al., Securities Regulation: Cases and Materials 800-04 (1991). In Brown and most cases like it, courts leave room to excuse the duty to read in certain circumstances: if the broker-customer relationship is long-standing, for example, or if the disclosure is unusually dense. E.g., Brown, 991 F.2d at 1032.

165. This common view is best given expression in the writings of Homer Kripke. E.g., Homer Kripke, The Myth of the Informed Layman, 28 Bus. LAw. 631 (1973). 
ing learning difficulties in evaluating investment options, themselves. ${ }^{166}$ Most sophisticated investors are busy with stressful lives and careers, and both want and need to rely on someone else for investment guidance. In the context of a full-service brokerage arrangement, they pay for the ability to rely, the ability to shift responsibility for evaluating the riskreturn probabilities of countless investment options. They will do this as long as they are persuaded, rightly or wrongly, of the broker's trustworthiness.

Having made the cognitive commitment to trust the broker, reliance follows easily. In the sales pitch, brokers motivate customers to want the investment. From that point on, the customer's tendency is to bolster. Assured by the broker that the investment is a good one, investors are hardly primed to look for reasons not to buy. Indeed, the only purpose for reading the prospectus would be to find reasons to challenge the broker's representations. Any discovery that these representations are contradicted by the prospectus would demonstrate that the customer's reliance thus far was a mistake-an ego-threatening realization that few investors seek. Moreover, if customers do discover apparent contradictions, they will have to confront the broker in order to back out of the transaction. Skillful brokers can then utilize their superior familiarity and training to embarrass their customers. The broker can respond by saying that the risk disclosure is meaningless, merely something found in almost identical form in nearly every document simply because overly cautious lawyers insist on it. ${ }^{167}$ Then, the customer is forced to explain why the investment really is too risky, an argument most customers are likely to lose.

Reading a prospectus after accepting the recommendation of a broker whom the customer is inclined to trust, then, is inconsistent with several phenomena: (1) the time-saving and responsibility-shifting reasons for using that broker in the first place, (2) the coguitive commitment to the broker as a credible source of recommendations, and (3) the

166. This is to some extent the product of information overload. For a comment on information overload and the duty to read from a behavioral perspective, see Melvin A. Eisenberg, Text Anxiety, 59 S. CAL. L. REv. 305 (1986) (arguing that it is reasonable for consumers to refuse to read dense form contracts). For one example of the role of salesperson influence generally, see Salvi $v$. Montgomerey Ward \& Co., 489 N.E.2d 394, 396-97 (IIl. Ct. App. 1986).

167. For example, judges in a number of CFTC administrative proceedings have noted brokers' tendencies to adopt this line of dismissal. E.g., Burkhart v. Zeff, [1986-87 Transfer Binder] Comm.

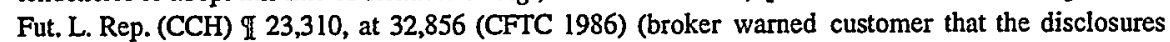
would "scare the hell" out of him, but to take note that they were a mere formality); Holmes v. Murlas Commodities, Inc., [1984-86 Transfer Binder] Comm. Fut. L. Rep. (CCH) I 22,669, at 30,847 (CFTC 1984) (broker advised investors to view disclosure statement as "legal technicality"). For a securities case involving a broker who told the customer that the signature to a disclosure document was "a mere formality," see Bruschi v. Brown, 876 F.2d 1526, 1528 (1 1th Cir. 1989). 
preference for making the investment. The motivation is not to read unless suspicions have otherwise been aroused..$^{168}$

The broker, in turn, can manipulate this motivation. Some brokers wait until the last possible minute before delivering any required prospectus, sometimes not until the formal "closing" of the transaction. ${ }^{169}$ By then, the customer's commitment to the investment is securely anchored. A decision to abandon the desired investment is framed as a potential loss. If necessary, the broker can give the customer an anticipatory rationalization for not reading by treating the document dismissively, as a boilerplate product of too much government regulation. For the customer to object and insist on reading at this point would be a significant and relationship-threatening act of defiance.

If there are so many reasons to expect that customers will rarely read prospectuses relating to securities recommended by their brokers, why does the duty to read survive and prosper? Some of the answers can be found earlier, in the introduction to Part II. Some judges may simply underestimate the regularity with which investors do not read, and thus treat those whose claims are litigated as aberrant. We have seen that this perception may well reflect an unrealistic bias. Other judges may be trying to channel behavior by creating an incentive to read. However, even putting aside the use of "recklessness" as a vehicle for this sort of functionalism, this argument also seems troublesome if we accept trust as widespread and predictable.

Another justification is perhaps more serious. As with the statute of frauds, ${ }^{170}$ a principal role of the duty to read may be to deal with the dif-

168. One suspects that in those situations where the customer does read, it is usually either because the customer is unusually compulsive or because the broker has done a poor job in solidifying the sales relationship. When the buyers are professional investment agents, they presumably have some greater level of time to give to the decision. Yet even here, the other factors may diminish the effectiveness of the written disclosures. For an interesting case involving the alleged oral misrepresentation of risk factors to wealthy, sophisticated investors in "roadshows" put on by an investment's promoters, see In re Hyperion Sec. Litig., [1995-96 Transfer Binder] Fed. Sec. L. Rep. (CCH) I 98,906 (S.D.N.Y. July 14, 1995). True to the case law, the court found the very aggressive oral assurances of safety cured by the risk disclosure in the written materials. Cases like Hyperion raise the question of why, if reasonable investors do in fact carefully review prospectuses to discover risks, why those planning the roadshow would ever permit-much less encouragecontrary oral representations such as those written into the scripts. Discovery of the discrepancy would threaten credibility, and hence the chances of the offering being successful. The most parsimonious explanation for the apparent willingness to make inconsistent oral representations to ostensibly sophisticated investors is that the brokers fully expect that the prospectus will not be read, or will be rationalized or trivialized away, thus allowing the sales pitcli to dominate.

169. See Mark Fadiman, Rebullding Wall Street 50 (1992). In many instances, the prospectus can easily be given to the buyer at the time any documentation is signcd, well after the customer has mentally committed to the purchase.

170. See, e.g., G.H.L. Fridman, The Necessity for Writing in Contracts Within the Statute of Frauds, 35 U. ToRonto L.J. 43 (1983); see also Joseph M. Perillo, The Statute of Frauds in the Light of the Functions and Dysfunctions of Form, 43 FordHAM L. REv. 39, 57 (1974) ("To avoid ambiguities, mistakes, and omissions of detail ... [written contracts] are to be drawn up ....") (citing 
ficult issues of credibility that arise in customer-broker disputes. Claims of oral fraud may be fabricated or produced by a biased memory. A proponent of the duty to read may argue that while such a duty might be dysfunctional if we have great confidence in our ability to determine who is telling the truth in these cases, we lack that confidence. Thus, we bias outcomes against the party who could have read and perhaps avoided the harm. A conclusive presumption against fraud except when the duty to read is excused or satisfied at least renders the dispute resolution process more efficient.

This argument's soundness depends on twin assumptions: first that customer fabrication or misrecollection is as probable as broker fraud, and second that our dispute resolution process is largely ineffective at resolving credibility battles about representations made. Although possible, these assumptions are not particularly compelling. We must therefore return to the battle of functional arguments: is it better to try to promote the more self-protective customer at the risk of encouraging broker cheating, or should we accept the reality of widespread reliance and concentrate on controlling broker opportunism? To be sure, immunity simply because of the often last-minute distribution of a prospectus is a delicious prospect to the Machiavellian broker.

Because of my concern about deliberate manipulation of the duty to read, I prefer a protectionist approach here, although my reaction is also partly emotional. It is ironic that lawyers for brokerage defendants aggressively promote a defense based on the claim that reasonable customers should be skeptical of broker recommendations-and thus read their prospectuses in search of inconsistencies-given how much money and effort brokers and firms spend on sending the message to investors that trust is wise and profitable, and how much they charge investors for their advice. ${ }^{171}$ The industry should accept the consequences of its marketing success. And, in any event, other less draconian legal mechanisms exist that can simplify the credibility battles in customerbroker disputes. The customer's duty to read should be excused in any setting where it is reasonable to rely generally on the broker's recommendations.

South Boston Iron Co. v. United States, 18 C. Cl. 165, 176 (1883), aff d, 118 U.S. 37 (1886)); Note, The Statute of Frauds and the Business Community: A Re-Appraisal in Light of Prevailing Practices, 66 YALE L.J. 1038, 1064 (1957) ("[T]he reduction of commitments and agreements to writing contributes to a smoother working business organization and eliminates the uncertainties and confusion which may accompany agreements involving only the spoken word.").

171. There is indeed an inconsistency between charging someone through full-service commissions for the generation of investment advice, and claiming that it is unreasonable to rely on it without double checking. The customer is "buying" the ability to simplify the investment decision making process. I am indebted to Elliott Weiss for this point. 


\section{Penny Stocks}

The legal analysis thus far has shown that, although most brokercustomer relationships should not be characterized as fiduciary, customers should have a broad right to rely on broker recommendations in relationships where trust is successfully generated. Plainly, then, the real issue-as is normally the case under securities law-involves the quality of disclosure accompanying the recommendation. Before turning to that question generally, however, it may be worthwhile to examine a setting in which the SEC has acted rather aggressively in regulating broker solicitations from a disclosure standpoint: the "penny stock" market.

Penny stocks are low-priced stocks sold over-the-counter. ${ }^{172} \mathrm{Be}-$ cause they usually involve unknown companies and thinly traded markets, and the market is made up largely of retail customers (many plainly unsophisticated), these securities present considerable opportunities for manipulation and deception. Some securities firms specialize in pushing such stocks with marketing efforts emphasizing the hard sell, typically relying on cold-call telephone solicitations to generate new customers-the classic boiler room technique. Calling scripts use nearly every available iufluence technique, coupled with promises that if the customer acts quickly, immense profits are quite likely. After all, if a person buys 5,000 shares of a stock priced at two dollars, just a fifty cent or one dollar price increase will quickly net a large gain.

The success of penny stock firms seems to underscore the greed and gullibility of significant numbers of investors-including many otherwise successful business and professional people. In contrast to the more conventional brokerage relationship, these sales are usually made quickly, without any face-to-face meeting. ${ }^{173}$ The firms do not typically have a high degree of name recognition, although they may choose names that prompt some heuristic recognition and thus create an illusion of reputation. ${ }^{174}$ While a series of transactions may involve a given customer, there is less expectation of a long-term advisory relationship and hence less justification for the customer to trust. Yet enough people buy their stocks to make these firms profitable-presumably a tribute to the power of motivated reasoning.

172. For a good overview, see generally Goldstein et al., supra note 78; see also Penny Stock Market Fraud: Hearings Before the Subcomm. on Telecommunications and Finance of the House Comm. on Energy and Commerce, 101st Cong., Ist Sess. (1989).

173. Among the many recent cases that detail the sales practices in this area, see SEC v. Hasho, 784 F. Supp. 1059, 1106-08 (S.D.N.Y. 1992). Some of the techniques of the penny stock operator are cataloged anecdotally in LEWIS, supra note 44 , at 23-37.

174. See supra note 76; see also Leslie Eaton, A Sign of Bad Brokers: Tap Dancing at the Roach Motel, N.Y. TIMES, May 5, 1996, § 3, at 3 (reporting names such as "Biltmore Securities"). 
Apart from some aggressive enforcement activity, the SEC's reaction to this phenomenon has resulted in an interesting set of rules. ${ }^{175}$ Some are concerned primarily with disclosure. For instance, each customer in a regulated penny stock transaction must receive a form document (Schedule 15G) warning investors about the generic risks and pitfalls of investing in penny stocks. ${ }^{176}$ This document contains suggestions like "Do not make hurried investment decisions," "Study the company issuing the stock," and "Know the brokerage firm and salespeople with whom you are dealing." Investors also must receive information regarding both price quotations and compensation paid to the brokers at the time of the transaction. Following the sale, the firm must provide a comprehensive monthly account statement. ${ }^{177}$ Penny stock brokers must also determine the suitability of particular transactions regarding each protected customer. ${ }^{178}$

Some of this regulatory structure, particularly the boilerplate language, is probably ineffective standing alone. ${ }^{179}$ The power of the penny stock rules is found not so much in the substance of the disclosure, but in the timing. Put simply, the rules seem designed to disrupt the selling process. A penny stock transaction is unlawful unless the broker has previously approved the investor's account. ${ }^{180}$ Account approval requires first that the investor provide the broker with written data regarding his or her financial situation and objectives, and sign an account form. The broker must then return to the investor a written statement with additional disclosures relating to the account, and the quotation and compensation disclosures must precede execution of the transaction. Even at this point a transaction can only be executed upon written instructions from the customer.

Note how difficult it is for the selling process to work, especially over the telephone. Sales training emphasizes the need to achieve closure before the customer has second thoughts or loses interest in the interaction. Under the rules, a substantial volume of paperwork must be exchanged between the broker and prospect between the time of the

175. SEC authority in this area was enhanced by the enactment of the Penny Stock Reform Act of 1990, Pub. Law No. 101-429, 104 Stat. 951. The SEC's rules are gathered in Reg. 15G, 17 C.F.R. $\S \S 240.15 \mathrm{~g}-1$ to $15 \mathrm{~g}-100$ (1995).

176. 17 C.F.R. $\$ 240.15 \mathrm{~g}-2$ (1995). For a criticism of the impotence of certain of these disclosures, see O. Dennis Hernandez, Jr., Broker-Dealer Regulation Under the New Penny Stock Rules: An Appraisal, 1993 ColuM. Bus. L. REv. 27, 57 ("[P]resent disclosure obligations required of brokers who sell penny stock are insufficient to ensure meaningful disclosures to unwary investors ....").

177. 17 C.F.R. $\$ \$ 240.15 \mathrm{~g}-3$ to $15 \mathrm{~g}-6$.

178. 17 C.F.R. $\$ 240.15 g-9$ (b)(2).

179. As mentioned previously, customers may rarely read such risk-disclosure materials if they are already motivated to buy. See supra note 166 and accompanying text.

180. 17 C.F.R. $\S \S 240.15 g-9$ (a)(2) to $15-9$ (b). 
first sales pitch and the execution of the transaction. This itself pointedly interferes with the ability to close. So do the required disclosures. Before the transaction is executed, the broker employing an oral sales script must pause to deliver potentially dissonant information about commissions and mark-ups for this particular transaction (unless there is some opportunity for the transmission of another writing). Without regard to the substance of any required disclosures, compliance with these rules diminishes the broker's ability to manipulate the timing and content of the sales presentation. The technique of instilling an unconflicted customer motivation to buy and quickly closing the transaction is constrained by the added information the broker must convey.

Whether the penny stock rules achieve their desired objective of countering fraud and abuse is not clear. Either way, they are controversial. ${ }^{181}$ True miscreants may simply ignore the rules or manipulate transactions so as to avoid the coverage of the rules. On the other hand, brokers selling stocks of perfectly legitimate small corporations under the rules will not be as effective in their marketing efforts as they would be otherwise, thus making it that much more difficult for those companies to raise capital. The very fact of the controversy, of course, amply demonstrates the tension between the goals of trying to protect investors with truly effective disclosure and not chilling the economically desirable act of selling securities-a tension that becomes all the more troublesome once we move away from a market with the history of abuse found in penny stocks.

\section{E. The Required Disclosure in a Sales Pitch: Risk and Suitability}

\section{The Nature and Source of a Duty to Disclose}

The penny stock rules provide a useful point of departure for considering what is usually the central legal question in a dispute involving a sophisticated customer: what else must brokers tell their customers when they recommend an investment? In other words, how much potentially negative or cautionary information must brokers provide before moving to close a sale? If broker-customer relationships are fiduciary in nature, then the answer is simple: they must affirmatively disclose all material information bearing on the transaction. ${ }^{182}$ But I have suggested that most relationships should not be, and frequently are

181. See Penny Stock Disclosure Rules, Exchange Act Release No. 30,608, [1991-92 Transfer Binder] Fed. Sec. L. Rep. (CCH) I 84,938, at 82,611-12 (Apr. 20, 1992). Compare Carolyn E. Lampe, Note, The Penny Stock Reform Act of 1990: A Costly Solution to a Serious Problem, 13 Geo. MASON L. Rev. 779, 797-98 (1991) (concluding added disclosure is not the optimal solution for penny stock market fraud) with Hernandez, supra note 176, at 57 (arguing that there is need for increased disclosure).

182. See, e.g., Restatement (SECOND) OF TORTS $\$$ 551(2)(a) (1977); Chiarella v. United States, 445 U.S. 222, 228 (1980). 
not, characterized as fiduciary. The law in this area is confused. Lawyers and judges often assume that brokers have a duty of full disclosure even in the absence of a fiduciary relationship, ${ }^{183}$ but neither the precise nature nor the source of such a duty has ever been articulated clearly. ${ }^{184}$ As a result, the extent of the disclosure obligation is unclear, even though many courts seem to want to set some limits.

When brokers make recommendations, they are expressing opinions (their own and/or their firms') that the transactions are in the customers' best interests. Our analysis to this point gives ample reason to treat these opinions as ones on which even sophisticated customers have a right to rely once trust has reasonably been established. ${ }^{185}$ In this setting, the doctrine of the fraud inherent in a half-truth, that people who speak have a duty to disclose all material facts necessary to make their statements not misleading, helps illustrate the proper disclosure obligation. ${ }^{186}$ The broker's duty is to couple a recommendation with any additional significant facts necessary to assess the nature and reliability of the broker's opinion. ${ }^{187}$

183. E.g., Chasins v. Smith, Bamey \& Co., 438 F.2d 1167, 1171 (2d Cir. 1970). Even so, some courts suggest a differential duty depending on whether the relationship is fiduciary. E.g., Prudential Bache Sec., Inc. v. Pitman, [1991 Transfer Binder] Fed. Sec. L. Rep. (CCH) I 96,170 (N.D. Ga. Apr. 4, 1991).

184. Tracing this source is particularly important under Rule $10 \mathrm{~b}-5$, because the Supreme Court has held that only where there is a pre-existing fiduciary relationship between the contracting parties is an affirmative duty of disclosure owed. Dirks v. SEC, 463 U.S. 646, 654 (1983) (holding that fiduciary relationship gives rise to broker or dealer's duty to disclose); Chiarella, 445 U.S. at 228; VIII Loss \& Seligman, supra note 135, at 3788-89. For a case-often still cited-rejecting the characterization of a broker-customer relationship as necessarily fiduciary but then articulating a rule of full disclosure, see Leib v. Merrill Lynch, Pierce, Fenner \& Smith, Inc., 461 F. Supp. 951, 953 54, 956 (E.D. Mich. 1978), aff d, 647 F.2d 165 (6th Cir. 1981).

185. The common law has properly been skeptical of basing fraud claims on simple statements of opinion. But the law has evolved to a point where the materiality of opinions turns into a question of the right to rely. Rehance on the opinion of another is justified-and thus a misstatement of opinion is actionable-if either a relationship of trust exists between the parties or the party charged with fraud has superior information or expertise on the matter in question. RESTATEMENT (SECOND) OF ToRTs, § 542(b)-(c) (1977); cf. Virginia Bankshares, Inc. v. Sandberg, 501 U.S. 1083, 1098 (1991) (imposing hability on board of directors for knowingly false statements of opinions). In most instances, as we have seen, both tests are satisfied in broker-customer interactions, whether or not the relationship is fiduciary. Brokers are skilled in generating trust, and do so largely by projecting a credible image of knowledge and expertise. Not surprisingly, the securities laws recognize a fairly broad right to rely on "expert" opinions. It is worth noting that-notwithstanding the contrary suggestion by the courts in Rule 10b-5 cases-thcre is a notable trend in the common law toward an affirmative obligation to disclose matcrial facts in circumstances where the seller has superior knowledge and expertise. For a comprehensive overview of this trend, see Nicola W. Palmieri, Good Faith Disclosures Required During Precontractual Negotiations, 24 SeTon HaLl L. Rev. 70, 130-34 (1993).

186. See, e.g., First Virginia Bankshares v. Benson, 559 F.2d 1307, 1314 (5th Cir. 1977), cert. denied, 435 U.S. 952 (1978).

187. A similar duty can also be derived from the obligation of good faith and fair dealing that is an implied contractual term in all customer-broker relationships. As we have seen, this is the best way of making sense of the shingle theory. More than anything else, good faith and fair dealing 
So understood, we can readily locate the source of the suitability obligation, one of the most powerful but dimly understood obligations that brokers are usually said to have. Probably the largest portion of broker-customer disputes involve a claim that the broker recommended an "unsuitable" purchase. ${ }^{188}$ Attempts to apply this duty in cases involving wealthy or sophisticated investors often collapse as the decision maker ponders the abstraction and indeterminacy of the concept of a suitable investment. Within the context of an overall portfolio, a bona fide investment will almost never be unsuitable per se. ${ }^{189}$ Investors are entitled to choose their level of risk, and they vary considerably in their individual risk preferences and capacities for risk evaluation. Appreciated for what it is, however, the suitability obligation becomes somewhat more manageable. When recommending an investment, the broker must balance the sales pitch with disclosure of those risk factors that are material in light of what the broker understands about the customer's needs and objectives. ${ }^{100}$ Virtually all suitability cases fit nicely within the half-truth doctrine, which in turn justifies their commonplace resolution under the law of fraud. ${ }^{191}$ And the same construct works to justify many

require honesty-in-fact. Brokers are free to pursue their self-interest within the relationship, but must do so without being overly opaque or disingenuous. A duty to disclose material information relating to the consistency of the recommendation with the customer's objectives follows naturally from this understanding. While this derivative notion works perfectly wcll as a conceptual matter, it is inconsistent with the Supreme Court's apparent limitation of the affirmative duty to disclose to fiduciary and fiduciary-like relationships. See supra note 184.

188. The suitability obligation is both an antifraud prohibition grounded in the sbingle theory and an affirmative requirement under securities self-regulatory organization rules. See V1II Loss \& SEligman, supra note 135 , at 3845-58; POSER, supra note $70, \S 3.3$; Harvey E. Bines, Selling Investment Objectives: The Suitability Doctrine-Part II, 4 SEC. REG. LJ. 418 (1977); Mark C. Jensen, Abuse of Discretion Claims Under Rule 10b-5: Churning, Unsuitability, and Unauthorized Transactions, I8 SEC. REg. L.J. 374, 380-90 (1991); Janet E. Kerr, Suitability Standards: A New Look at Economic Theory and Current SEC Disclosure Policy, 16 PAC. LJ. 805 (1985); Robert H. Mundheim, Professional Responsibilities of Broker-Dealers: The Suitability Doctrine, 1965 Dukz LJ. 445; Stuart D. Root, Suitability-the Sophisticated Investor-and Modern Portfolio Management, 1991 COLUM. BuS. L REv. 287.

189. One of the important insights in this area is that the extreme risk of an investment cannot be considered individually, but must be viewed in the context of an overall portfolio. One of the first articles pushing this insight is Stephen B. Cohen, The Suitability Rule and Economic Theory, 80 YALE L.J. 1604, 1634 (1971).

190. One troublesome question arises with respect to the divergence between the customer's apparent level of sophistication and his or her actual understanding of the investment. Based on the analysis in Part l, we would predict that customers generally try to convey an impression of greater understanding and sophistication during the interaction than they really have. The broker may or may not discover the discrepancy (and may or may not try to take advantage of it). Clearly, the legal standard should be in terms of what a reasonable broker would believe based on the facts and circumstances of the particular interaction or relationship.

191. For examples of the use of Rule $10 \mathrm{~b}-5$ in resolving a suitability claim, see McDonald v. Alan Bush Brokerage Co., 863 F.2d 809, 813 (11th Cir. 1989); Lefkowitz v. Smith Barney, Harris Upham \& Co., 804 F.2d 154, 155 (1st Cir. 1986); Clark v. John Lamula Investors, Inc., 583 F.2d 594, 600 (2d Cir. 1978). At least one court has suggested that absent a fiduciary relationship, an unsuitability claim cannot lie, because an affirmative duty to disclose had not arisen. See National 
of the other duties courts commonly recognize, such as the "know your security" rule, ${ }^{192}$ the mandatory disclosure of most conflicts of interest, ${ }^{193}$ and the prohibition against churning ${ }^{194}$ and excessive mark-ups. ${ }^{195}$

Union Fire Ins. Co. v. Woodhead, 917 F.2d 752, 757 (2d Cir. 1990) ("Since National Union owed no duty to [plaintiff assignees of note], its failure to inform them of the alleged unsuitability of the investment" did not make National Union party to fraud.). That may be true where there is a sale but no recommendation to the purchaser. When there is a recommendation, the issue is no longer one of silence but rather of half-truth.

192. This rule holds that it is fraudulent to recommend a security without reasonable investigation into its quality. See Hanly v. SEC, 415 F.2d 589, 595-96 (2d Cir. 1969); see generally VIII Loss \& SELIGMAN, supra note 135 , at $3840-45$ ("[S]alespersons . . . may not rely blindly on information furnished by the broker-dealer by whom they are employed ....").

193. See SEC v. Blavin, 760 F.2d 706, 711 (6th Cir. 1985) (disclosure of investment in securities recommended to customer); Chasins v. Smith, Barney \& Co., 438 F.2d 1167, 1171 (2d Cir. 1970) (disclosure of marketmaker status). The SEC and the NASD have in some instances partially resolved this issue by rulemaking (see Rule 10b-10), although the disclosure requirements have been limited to transaction confirmations. One can readily question the usefulness of this disclosure in terms of the buyer's decision making.

Requiring disclosure of conflicts of interest raises some interesting issues. For example, should brokers be obliged to disclose that they are receiving above-normal commissions with respect to the recommended security? The courts have shied away from such a conclusion. See Platsis v. E.F. Hutton \& Co., 946 F.2d 38, 41 (6th Cir. 1991), cert. denied, 582 U.S. 984 (1992); Shivangi v. Dean Witter Reynolds, Inc., 825 F.2d 885, 889 (5th Cir. I987); Robert T. Greene, Note, Differential Commissions as a Material Fact, 34 EMORY L.J. 507, 508-09 (1985). Yet one can readily see why a reasonable investor might attach significance to such information. Perhaps the justification for nondisclosure is that investors (even from a behavioral perspective) understand that the recommendation usually comes from the firm rather than the individual broker, and the nature of the compensation program says nothing about any conflict of interest for the firm. More realistically, this conclusion has a distinctly gamesmanship tint: the rules of the road do not extend to a firm's internal strategic deliberations about how best to move its inventory. Forcing disclosure of this sort of conflict inherent in the structure of the industry comes too close to forcing brokers to "unsell" their products. Note that recently, an Advisory Committee to the SEC recommended that firms diminish their reliance on commission structures. See supra note 70.

194. Churning arises when a broker causes excessive trading in a customer's account. See Mihara v. Dean Witter \& Co., 619 F.2d 814, 824-25 (9th Cir. I980); VIII Loss \& Seligman, supra note 135, at 3874-87; Norman S. Poser, Options Account Fraud: Securities Churning in a New Context, 39 Bus. LAw. 57I, 57I (1984).

195. The NASD has a specific fair practice rule limiting mark-ups and commissions. That, of course, is well within its discretion as a means of promoting the reputation of the securities industry. See generally NASD Rules of Fair Practice III § 4, reprinted in NASD MANUAL II 2154 (I995); VIII Loss \& SELIGMAN, supra note 135, at 3798-3802. The specific rule aside, however, it might seem curious that we compel disclosure of mark-ups in non-fiduciary settings. Disclosure of profit is hardly the norm in most sales settings. But at the same time, we must realize that as intangibles, securities have little value apart from what they are worth on the market. Thus, the fact that the security can be acquired on the open market for a significantly lower price (or that there is no fair and open market at all) is the sort of security-speciflc information that is sufficiently dissonant with the broker's recommendation that it should be included in the category of information that must be disclosed. And in fact, the courts and the SEC readily conclude that excessive mark-ups are fraudulent. See id. at 3772-98. This is one of the conventional uses of both the fiduciary and shingle theories. 


\section{How Effective Must the Disclosure Be?}

It is not all that helpful simply to articulate a duty to disclose. If the behavioral literature teaches anything, it is that a customer motivated to buy an investment becomes less risk sensitive. The broker's selfinterest is in generating the motivation and the trust to both cause and enable the customer to rationalize the investment as a reasonable one. To motivate the customer, the broker will often employ some combination of influence techniques designed to increase the willingness to take some risk (through loss framing, etc.) and diminish the saliency of that risk.

Under these circumstances, much disclosure will be ineffective. As we saw earlier, allowing for disclosure through a written prospectus or comparable document creates an environment readily manipulable by a broker. The disclosures may not be read at all. Even if the disclosure comes to the customer's attention, it may easily be filtered out or misinterpreted. Research on the use of labels or printed form warnings in consumer purchases amply bears out this concern. ${ }^{196}$ The consumer is naturally inclined to place too little weight on risks that have a small probability of occurring, especially if the decision can be made in a situation where he or she senses some control. If the consumer is motivated to make the purchase, cognitive vigilance is further decreased. For disclosure to be effective, then, the risk must be made sufficiently salient to communicate not only the possibility of its occurrence but also the probability. Merely indicating possibility of risk creates too much of an opportunity for the customer, perhaps with the help of the salesperson, to dismiss the disclosure as trivial or boilerplate. There must be some sense, therefore, of the extent of the risk before the customer is in a position to consider it seriously.

196. See Howard Latin, "Good" Warnings, Bad Products and Cognitive Limitations, 41 UCLA L. REv. 1193 (1994). For analysis in other consumer settings, see William N. Eskridge, Jr., One Hundred Years of Ineptitude: The Need for Mortgage Rules Consonant with the Economic and Psychological Dynamics of the Home Sale and Loan Transaction, 70 VA. L. REv. 1083, 1112-33 (1984); Eric J. Gouvin, Truth in Savings and the Failure of Legislative Methodology, 62 U. CINN. L REv. 1281, 1299-1300 (1994) (addressing bank-customer disclosure); Edward L. Rubin, Legislative Methodology: Some Lessons from the Truth in Lending Act, 80 GEo. L.J. 233 (1991); Norman Silber, Observing Reasonable Consumers: Cognitive Psychology, Consumer Behavior and Consumer Law, 2 LOY. CONSUMER L. REP. 69 (1990); Jeff Sovern, Toward a Theory of Warranties in Sales of New Homes: Housing the Implied Warranty Advocates, Law and Economics Mavens, and Consumer Psychologists Under One Roof, 1993 Wis. L. REv. 13 (home-buyer-seller disclosure). Quite apart from the motivational aspect, information overload and complexity can also pose a problem to information search. On the difficulties in designing warnings that are actually processed during the flood of information, see WESLEY A. MAGAT \& W. KIP Viscusi, InFoRMATIONAL APPROACHES TO Regulation 90-92, 104-05 (1992); James R. Bettman et al., Cognitive Considerations in Designing Labels for Presenting Risk Information, 5 J. PUB. POL'Y \& MARKETING 1 (1987). But see Schwartz \& Wilde, supra note 119 (questioning the desirability of judicial and legislative interventions into the market to correet imperfect information). 
The issue here has much in common with the question of informed consent in medical practice. The role of medical consent has become more prominent as courts and policy makers recognize doctors' conflicts of interest and the costs associated with too much deference to medical judgment. ${ }^{197}$ But it is hard to enforce a rule of informed consent. Perhaps even more than investors, consumers of medical care both need and want to shift the responsibility for difficult decisions. ${ }^{198}$ The doctor has an overwhelming influence over the patient in the way choices are framed and the manner in which they are presented, even when the patient makes the ultimate decision. Merely identifying possible risks is not enough.

To be truly effective, then, securities risk disclosure must at least temporarily disrupt the selling process. The customer's cognitive attention must be turned toward considering risks, not dismissing them, toward taking responsibility for the decision, not shifting it away. For some investors, it is unrealistic to expect this to happen at all in the absence of strong intervention by some neutral expert. For others, however, we can assume that risk-related information will affect their deliberations so long as it is sufficiently salient and presented before the customer achieves cognitive closure. What is important here is that the customer actually become aware of the disclosure, and not just have it available. The SEC's penny stock rules are plainly an effort in this direction, although their power may lie more in the disruption of the influence process through delay and paperwork than in the disclosure itself. ${ }^{199}$

Customer protection will be maximized by a standard requiring a broker to disclose all significant risk factors going to the suitability and soundness of the recommended investment in a way that captures the attention of the competent investor. Such a presentation can be oral or in an easily accessible writing, as long as the risk presentation achieves equal dignity to the sales pitch. The message must be that there are also good reasons not to make this purchase. Anything short of this offers the seller too much of a temptation to manipulate the sales interaction so that a strong recommendation subconsciously preempts diligent evaluation of the risk in light of the trust relationship so carefully created.

197. See Peter H. Schuck, Rethinking Informed Consent, 103 Y ALE L.J. 899, 927-28 (1994); see also James F. Blumstein, Health Care Reform and Competing Visions of Medical Care: Antitrust and State Provider Cooperation Legislation, 79 CORNELl L. Rev. 1459, 1474-75 (1994).

198. See THALER, supra note 29 , at 17.

199. One author has suggested that for the penny stock disclosures to be effective, Form 15G would have to move beyond its mild warnings and tell investors explicitly that according to a recent study, investors have lost over $\$ 2$ billion in misguided penny stock investments. See Hernandez, supra note 176 , at 39 . 
Most importantly, the burden of proof should be on the broker to show the effectiveness of the risk and suitability disclosures. ${ }^{200}$

Admittedly, this approach is costly. The actual cost of the effective disclosure documentation is itself significant. There is also a risk to the broker that the cost of doing business will increase where the possibility of inadequate documentation or of fact-finder error in judging a customer's awareness of disclosure creates liability issues. In any event, there will be more customer claims than under a rule favoring the defendant. There may also be an excess of disclosure, although a rule requiring the broker to prove that the customer was actually made aware of the risk would force the broker to evaluate carefully the point at which the level of disclosure ceases to be cost-justified. The feared practice of loading an excessive amount of information into a prospectus, thereby diluting what really is important, would not offer protection.

An additional cost is imposed on the selling process itself. If risk is understated or otherwise masked the disclosure will be ineffective. But making risk salient enough to capture the attention of the prospect-a process referred to as sharpening ${ }^{201}$-may easily provoke an overreaction. People place too much weight on risks that are particularly vivid and easily recalled. Causing someone to focus on risk increases anxiety. In a sales setting, a prospect can (and often will) seek to eliminate the stress by terminating the sales interaction. ${ }^{202}$ If there is one thing that salespeople are taught to avoid, it is offering the prospect reasons not to make the purchase. Here, we are in some sense asking the seller to "unsell" the investment.

There is no avoiding this dilemma. We are faced with a stark choice between facilitating the sales process in the name of capital formation or offering protection against sales overreaching. My sense is that although the burdens of the kind of disclosure I advocate are significant, they are manageable. They are not the sort that lead to the open-ended exposure inherent in fiduciary ideology. While the question is a close one, imposing an enhanced risk disclosure obligation is

200. Given the oral nature of most sales interactions, the question of whether the caution was given equal dignity to the sales pitch can readily become a difficult matter of credibility. That is why the burden of proof is so important. On average, the seller is in the far superior position to document its own disclosures, whether through tape recordings of phone conversations, or clear disclosure statements signed or initialed by the purchaser. Sales scripts in the possession of the seller that demonstrate, as they often do, an effort to bury risk factors in a carefully structured pitch would be good evidence to be held against the broker.

201. See GiLovich, supra note 37, at 91-94.

202. See Philip G. Zimbardo \& Michael R. Leippe, The Psychology of Attitude Change and Social Influence 345, 355 (1991). Some psychologists have noted people's tendency to polarize risk: once they are prompted to cure their underestimation, they will react by overestimating it. See Slovic et al., supra note 12, at 292-300. 
an appropriate response compared to the alternative of allowing risk disclosure to be buried in the sales process.

\section{Scienter and Other States of Mind}

In many customer-broker disputes, fact-finding stumbles over the issue of the individual broker's state of mind. ${ }^{203}$ Brokers often come across during the proceeding as honest, well-meaning people with impressive social credentials. Of course, we might be skeptical of that image: their training, as much as anything, teaches them to present themselves as people to be trusted, emphasizing the need for credentialing precisely because people too easily associate church activity, charitable work and Chamber of Commerce-type service with good character. $^{204}$ If this is how the fact-finder is inclined to see the broker, the case will be affected in two ways. If the dispute centers on a credibility battle about whether the risks were properly disclosed, a presumption of the honest broker will strengthen the inference that proper risk disclosure was made. Even if nondisclosure is assumed, the broker's character may generate an inference that the omission was unintentional. In those fraud cases where scienter is required for the imposition of liability, an "honest broker" inference will be fatal to the customer's claim.

Our behavioral inquiry should caution against just these inferences, and not just out of a cynical suspicion that evidence of the broker's appearance and character can be created artificially, for the court as well as for the customer. As observed earlier, people (especially successful ones) are motivated to bias their perceptions in order to enhance selfimage. When possible, information that one's acts are harmful is filtered out or rationalized. As a result, activity motivated by self-interest will often be perceived as reasonable and justified. For this reason, most brokers probably form an inflated impression of the value of what they do and the quality of what they sell. If the brokerage firm is successful at sales management, it will offer its salespeople an appealing plausibility structure to cling to.

Therefore, it is quite possible for brokers who consider themselves decent and honest people to push securities without adequately disclosing the risks. They are motivated not to see the risks, or to trivialize them. Their assessment of the suitability of an investment will be bi-

203. So, too, in fraud generally. See LEFF, supra note 16 , at 183 . There are, of course, different state of mind standards depending on the legal rule in question. Tort law generally imposes a scienter requirement for fraud (as does Rule 10b-5 under the federal securities laws). Brokerdealer disciplinary proceedings require willfulness. On the other hand, the common law recognizes negligent misrepresentation, and principles of contract and fiduciary duty altogether preempt the parties' state of mind as a controlling issue.

204. See supra note 113 and accoinpanying text. 
ased. To eliminate liability simply because the individual broker has successfully blinded himself or herself would create a serious underinclusiveness in terms of both the compensation and the deterrence values of the liability system.

Two legal conclusions follow. One is that fact-finders must be careful not to confuse scienter with malice. ${ }^{205}$ If a broker is aware of a risk, failure to disclose should not be excused simply because there was no contemporaneous appreciation of wrongdoing, of specific opportunistic behavior toward the customer. More importantly, it is best to direct the state of mind inquiry at the brokerage firm as a whole, not just at the individual broker. Firms can too easily mislead their own salespeople by withholding information about risk or subtly mischaracterizing it. Furthermore, the question should be simply whether people in the firm possessed sufficient information about the risk in question. Anything more than this invites fruitless inquiry into the biased and self-serving perceptions of the firm's brokers and managers.

\section{F. The Institutional Purchaser}

As we have observed, many claims against brokers involving the sale of unsuitable or excessively risky securities have been made by institutional purchasers. These claims prompt a healthy skepticism, for the professional investor is the one least likely to be deceived or to trust foolishly. When motivation interferes with due deliberation for a professional investor, it is more likely to be self- rather than externally generated. ${ }^{205}$ There is a strong temptation, moreover, to make wealthy institutions pay for their imprudence or gullibility. Rather than allowing them to shift their losses elsewhere, reduced broker liability may force these investors-classic repeat players-to learn from their mistakes. Yet we have also seen that im many circumstances it is both natural and foreseeable for professional investment agents to rely wrongly on the representations and recommendations of securities salespeople. There is no reason to believe that the principal is somehow at fault simply because its agent was tricked.

By and large, the law takes a moderate approach in this area. An institutional purchaser is not barred from suing, but courts are nonethe-

205. For a case that appears to do this, see Shivangi v. Dean Witter Reynolds, Inc., 825 F.2d 885, 889 (5th Cir. 1987). There, the court found insufficient evidence that the broker acted with scienter in failing to disclose a program of differential commissions. Given that the broker surely was aware of the program, this result is hard to fathom if we assume (as the court did arguendo) that the program was material. See supra note 193.

206. And when a motivation is powerful enough to overcome the rational dccision making of a professional investment agent, the kind of intervention necessary to alter that motivation would have to be equally or more intense. In this sense, the cost of intervention will be higher for profcssional investors than for non-experts. 
less fairly rigorous in applying such standards as materiality and right to rely. ${ }^{207}$ Following this sensible balance, there is no reason to revise the basic standards discussed above just because the plaintiff is an institutional investor. This includes the suitability rule, so long as that rule is understood narrowly in its disclosure-oriented sense. Like any sophisticated investor, an institution must determine its own objectives and tolerance for risk. Once the broker understands these objectives, it can be considered false and misleading to recommend an unsuitable investment to the institution's agent. That is, the broker may not offer a specific recommendation without effective disclosure to assure that the customer actually understands any material inconsistency between the articulated goals and the instrument under consideration. Recent initiatives by banking and securities regulators to impose some duty regarding the suitability of complex investments for institutional buyers are perfectly consistent with good policy. They should not, however, go beyond a true disclosure obligation and create a fiduciary-like system where loss shifting occurs too easily, especially given the tendency of some investment managers to profess a greater sophistication than they really have. ${ }^{208}$

The same moderation should apply in elaborating a separate but related legal issue specific to sales to investment agents: the scope of the rule barring any person from knowingly inducing or participating in a

207. See Fletcher, supra note 3, at 1086-90, 1097-99. On the application of fiduciary principles, see West Virginia v. Morgan Stanley \& Co., 459 S.E.2d 906, 913 (W. Va. 1995); John Quintmeyer, Fiduciary Obligations in the Derivatives Marketplace, 28 REv. SEC. \& CoMmod. REg. 179 (1995).

208. See Coffee, supra note 48 , at B6. In the wake of some of the most recent derivatives scandals, a number of regulators have implemented or proposed rules requiring sellcrs to make greater effort to be sure that either the purchase is suitable or the customer has the knowledge and expertise to make its own suitability determination. For a comprehensive overview of these proposals, see Goldman, supra note 126 , at $1126-45$. Of particular note here is an NASD rule and interpretation approved in the summer of 1995 clarifying the suitability requirement for institutional sales of all sorts, not just derivatives. See NASD Approves New Interpretation of Suitability Obligations to Institutions, 27 SEc. REg. \& L. REP. (BNA) 1220 (July 21, 1995); the new interpretation has been revised and republished by the SEC for public comment, Exchange Act Release No. 34-36973, 61 SEC Docket 1164 (March 14, 1996). The suitability standard stands unless it is clear after such inquiry that the customer has the capacity to evaluate risk on its own and is making an independent investment decision. Going in the other direction was a legislative proposal, included in the proposed "Capital Markets Deregulation and Liberalization Act of 1995," H.R. 2131, 104th Cong., 1st Sess. (1995), which provided that brokers are not liable for the investment decisions of institutional customers unless there was fraud involved or a contractual agreement between broker and customer provided for such responsibility. Fields Introduces Broad Bill to Reform Federal Securities Laws, 27 SEC. REg. \& L REP. (BNA) 1255 (July 28, 1995). The intent of the provision was to limit suitability responsibility. Industry Groups Largely Favor Bill's Suitability, Preemption Provisions, 27 SEC. REg. \& L. REP. (BNA) 1901 (Dec. 8, 1995). The analysis in this Article shows why such an approach is misguided. Fortunately, this provision has been dropped from the most recent version of the legislation. See Jeffrey Taylor, Securities Bill is Passed Unanimously By Panel Afier It's Softened for Critics, WALL ST. J., Mar. 8, 1996, at A12. 
breach of fiduciary duty by another. ${ }^{209}$ Recall that one of the problems inherent in institutional investing is the risk that the buyer's investment agent will be acting to satisfy a personal desire or goal in making the purchase. The agent may be seeking to protect her job or reputation, or to get richer, or might simply be shirking. Can brokers sell securities to an investment agent if they are aware that the agent is acting either carelessly or disloyally? This issue was essentially posed recently in a West Virginia Supreme Court case, West Virginia v. Morgan Stanley \& Co. ${ }^{210}$

No doubt there are many instances when this rule should apply. Bribing the agent to make an unsuitable investment is clearly wrongful, for example. So is selling securities that the seller knows will be used as part of a scheme of embezzlement or misappropriation by the buyer's agent. And we might add to this list selling securities where the seller knows that the buyer's agent lacks authority to make the purchase, although this situation can just as easily be handled by basic principles of agency law.

Nothing in the common law rule agamst assisting a breach of fiduciary duty, however, necessarily limits its application to these examples, and one must wonder whether this doctrine could not become something of a loose cannon in the law governing sales interactions. Taken to an extreme, it could suggest that anytime a buyer seems to be acting inconsistently with an objective standard of the institution's needs, the seller must refrain from the transaction-regardless of what was or was not said-because negligence is usually a breach of fiduciary duty. There is, however, one use of this doctrine that makes a good deal of sense if carefully applied. If -as might well have been the case in the Bankers Trust dispute with Gibson Greeting Cards-the salespeople knew that the buyers were making significant judgmental errors or omissions in their purchasing decisions, then it would seem that the salespeople should have taken steps to assure that any required risk disclosure was made available to the buyers' superiors within the organiza-

209. A good illustration of the rule and its application is S\&K Sales v. Nike, 816 F.2d 843, 849 . 50 (2d Cir. 1987); see also Whitney v. Citibank N.A., 782 F.2d I106, 1115 (2d Cir. 1986). The rule is found in various forms in the common law: under the law of torts, see RESTATEMENT (SECOND) OF TORTS § 876(b)-(c) (1977); agency, see RESTATEMENT (SECOND) of AGENCY § 312 (1957); and trusts, see Restatement (SECOND) of TRusts $\S 326$ (1957). For some cascs-most involving pension plans - that invoke this doctrine in the securities context, see Pension Benefit Guaranty Corp. v. Ross, 781 F. Supp. 415, 419-20 (M.D.N.C. 1991); Pension Fund Local 701 v. Omni Funding Group, 731 F. Supp. 161, 175-76 (D.N.J. 1990).

210. In Morgan Stanley, the court treated as a jury question whether Morgan had aided and abetted a violation of a state statute barring the use of state funds for "speculation." West Virginia $v$. Morgan Stanley \& Co., 459 S.E.2d 906, 913 (W. Va. 1995) The court noted, among other things, that a question of fact existed about whether Morgan was guilty of improper participation even though there was little question that a high degree of risk was being undertaken by state agents "who were not potential nominees for the Nobel Prize in Economics." Id. at 919. 
tion. ${ }^{211}$ Even apart from this principle of trust and agency law, there is much to be said for the idea that a rule of effective disclosure requires the provision of risk information to a broader set of persons associated with the institutional purchaser once there is knowledge that those specifically responsible for the investment decision are disregarding the institution's investment objectives.

\section{CONCLUSION}

Like classical economics, both the common law and securities regulation have long worked largely from the simplifying assumption of the rational actor. ${ }^{212}$ Whether or not the assumption is reasonably accurate, it has the virtue of myth: it gives order to the otherwise chaotic, offering a comforting confidence that behavior is controllable through simple interventions like disclosure and contract enforcement. In other words, law has the appearance of greater power and efficacy if we assume a rational world. ${ }^{213}$ Few doubt that rationality plays a substantial role in ordering the securities markets. Thus, it should not be surprising that most doctrinal structures invoke the assumption of dominating ratiouality. The emphasis in securities law is on making accurate information available; the investor is presumed to be willing and able to use it wisely.

This Article risks the inevitable loss of comfort and stability that comes when myths are challenged. In place of the polarized claims of brokers and customers facing each other in disputes, and the stereotypes that people in general often bring to the issue, $I$ have substituted a joint responsibility hypothesis to explain a significant segment of suboptimal investment decision making by otherwise sophisticated investors. While the possibilities of outright broker deceit or simple investor greed are hardly trivial, a large middle ground of such decisions can be explained by the confluence of motivational influences. The influences lead the investor, without realizing it, toward rationalization and wishful thinking, often triggered by the intervention of a broker who has learned to take advantage of those motivations and guide them toward the desired investment. Repeat players will learn from experience, but

211. See Coffee, supra note 48 , at B6.

212. For a discussion of this assumption, see Amartya K. Sen, Rational Fools: A Critique of the Behavioral Foundations of Economic Theory, 6 PHIL. \& Pur. AFF. 317 (1976).

213. With respect to a similar motivation for the illusion of coherence and determinacy in the law, see J.M. Balkin, Understanding Legal Understanding: The Legal Subject and the Problem of Legal Coherence, 103 YALE L.J. 105, 144-51 (1993); see also Langevoort, supra note 31, at 885-86; Jonathan R. Macey, Civic Education and Interest Group Formation in the American Law School, 45 STAN. L. REv. 1937, 1942-45 (1993). As we have seen, the assumption of rationality also allows the judge or observer to marginalize the behavior of victims who act foolishly, condemning them to their deserved fate. 
slowly, with ample opportunity for continued exploitation in the meantime.

It is always difficult for the law to handle the assignment of joint responsibility. It becomes easy-too easy if our insights about observers' self-serving biases are on the mark-to blame the seemingly sophisticated victim for foolishness to which "we" would never have succumbed. But given the likely pervasiveness of motivated reasoning, going too far in this direction allows for too much broker opportunism, with an attendant misallocation of economic resources. On the other hand, we wish to preserve some room for forcing people to learn from their mistakes, slowly or not, and to minimize the heavy enforcement costs that protectionism entails. And, perhaps as significantly, we are reluctant to interfere unduly with the salesmanship that-for better or worse-may be an important part of the capital formation process. The relatively moderate policy prescriptions suggested in Part II try to strike something of a balance, but with greater clarity and candor than we see in the ambivalent, often incoherent, body of law that governs brokercustomer interactions today.

After all this, we still do not know how much mischief really goes on in the brokerage business. We have seen that well-trained brokers can take advantage of their customers' own greed, anxiety, and ego in pushing particular investments that would not otherwise be purchased. That is not to say that all brokers do this, much less that all sales interactions are manipulative. Much that goes on in these interactions is the legitimate provision of information and advice. But on the assumption that in highly competitive business environments that which is profitable will often be pursued, it is naive to suggest that manipulation is the modus operandi only of the industry's small number of undiscovered bad apples. Protestations in this regard probably involve more selfdeception than cynicism. In all likelihood, most of whatever manipulation goes on is repressed and rationalized; the bad apple story too easily becomes another useful myth.

To say this is not to engage in intellectual broker-bashing. To the contrary, the message should be a constructive one. More than anything, understanding the behavioral economics of investment sales is cause for professional self-reflection. Those in the securities industry committed to a more ethical climate should give more attention to why brokers and customers behave as they do, seeing how actions that in the abstract seem like conventional, culturally legitimate forms of sales behavior can become a proximate cause of significant financial harm. Good brokers should learn psychology not simply to enhance their sales productivity but to see how their customers-and they-can readily fall subject to rationalization, allowing the rosy glow of their own 
self-image to obscure the risk of harm their actions generate. Behavioral economics should be a source of insights for industry and selfregulatory organization training, supervision and compliance efforts.

Lawyers and securities regulators have cause for reflection as well. Both judicial and regulatory policy making can readily suffer from their own self-serving inference and illusion of control, overestimating the likely benefit to flow from chosen regulatory strategies, underestimating their costs. In the world of investments, motivation sometimes matters as much as information, and motivation-like learning from experience-is a sticky phenomenon. In the end, then, moderation and restraint are indeed well advised. Even if we want to control it, the sale of hope and risk is a form of economic activity that will often elude our grasp. 
